\title{
Stratiform and Strata-Bound Zn-Pb-Ag Deposits in Proterozoic Sedimentary Basins, Northern Australia
}

\author{
Ross R. Large, ${ }^{\dagger}$ Stuart W. Bull, Peter J. McGoldrick, Steve Walters, \\ Centre for Ore Deposit Research, University of Tasmania, Private Bag 79, Hobart, Tasmania, Australia 7001
}

GEOFF M. DERRICK,

P.O. Box 184, Corinda, Queensland, Australia 4075

AND GRAHAM R. GARR

CSIRO Exploration and Mining, P.O. Box 136, North Ryde, NSW, Australia 1670

\begin{abstract}
In terms of zinc, lead, and silver metal endowment, the Proterozoic sedimentary basins of northern Australia rank number one in the world. The Mt. Isa-McArthur basin system hosts five supergiant, stratiform, sedimentary rock-hosted Zn-Pb-Ag deposits (McArthur River, Century, Mt. Isa, Hilton, and George Fisher) and one supergiant strata-bound Ag- $\mathrm{Pb}-\mathrm{Zn}$ deposit (Cannington). These superbasins consist of units deposited during three nested cycles of deposition and exhumation that occurred in the period from 1800 to $1580 \mathrm{Ma}$. The cycles took place in response to far-field extension and subsidence associated with a major northward-dipping subduction zone in central Australia. All major stratiform zinc-dominant deposits occur within rocks of the sag phase of the youngest Isa superbasin, which was cleposited between 1670 and $1580 \mathrm{Ma}$. The strata-bound silver- and lead-rich Cannington deposit is hosted by high-grade metamorphosed clastic sedimentary rocks that are temporal correlatives of the basal extensional phase of the Isa superbasin. It exhibits distinct differences from the stratiform zinc-dominant deposits but shows similarities with Broken Hill-type deposits.

The major stratiform $\mathrm{Zn}-\mathrm{Pb}$-Ag deposits exhibit many similar geological and geochemical features that include: (1) location close to regionally extensive normal and strike-slip synsedimentary faults, (2) organic-rich black shale and siltstone host rocks, (3) laminated, bedding-parallel synsedimentary sulfide minerals, (4) stacked ore lenses separated by pyritic and $\mathrm{Fe}-\mathrm{Mn}$ carbonate-bearing siltstones, (5) lateral zonation exhibiting an increasing $\mathrm{Zn} / \mathrm{Pb}$ ratio away from the feeder fault, (6) vertical zonation exhibiting decreasing $\mathrm{Zn} / \mathrm{Pb}$ ratio upstratigraphy, (7) an extensive strata-bound halo of iron- and manganese-rich alteration in the sedimentary rocks surrounding and along strike from ore, (8) a broad range of $\delta^{34} S$ values for sulfide minerals, from about 0 to 20 per mil, with pyrite exhibiting a greater spread than base metal sulfides, and (9) lead isotope ratios that indicate derivation of lead from intrabasinal sources with interpreted lead model ages being similar to the measured zircon $\mathrm{U}-\mathrm{Pb}$ ages of the host rocks. These common features demonstrate that the stratiform $\mathrm{Zn}-\mathrm{Pb}-\mathrm{Ag}$ ores formed approximately contemporaneously with sedimentation and/or diagenesis. The exact timing of mineralization relative to these processes varies from deposit to deposit. However, metamorphic overprints in some deposits (e.g., Mt. Isa, Hilton, Dugald River, Lady Loretta) have lead to recrystallization of sulfide minerals, making it difficult to interpret primary paragenetic relationships and absolute timing of mineralization. Mount Isa is the only northern Australian stratiform $\mathrm{Zn}-\mathrm{Pb}$ - $\mathrm{Ag}$ deposit that has spatially associated high-grade copper mineralization.

Textural and isotopic data for the stratiform $\mathrm{Zn}-\mathrm{Pb}-\mathrm{Ag}$ deposits suggest there is a spread of ore depositional processes from synsedimentary exhalative to syndiagenetic replacement. At McArthur River, for example, the high-grade laminated ores principally formed by synsedimentary exhalative processes. However, there is good evidence that the lower grade ores at the margins of the deposit formed at shallow depth in the organic-rich muds by syndiagenetic replacement and open-space fill. At Century, on the other hand, the textual and lead isotope evidence indicate the major mineralization probably formed by syndiagenetic replacement about 20 m.y. after sedimentation. At Mt. Isa, Hilton, and George Fisher, overprinting metamorphism precludes determination of the precise timing of ore deposition relative to sedimentation and diagenesis, but recent studies at the least metamorphosed George Fisher deposit suggest that syndiagenetic replacement was likely dominant.

The lack of footwall stringer zones or hydrothermal vent complexes in the $\mathrm{Zn}-\mathrm{Pb}$-Ag deposits, coupled with the lateral and vertical $\mathrm{Pb}-\mathrm{Zn}$ metal zonation, suggest the ores are of the vent-distal type, forming at some lateral distance from the hydrothermal vent or feeder fault. The laterally extensive strata-bound Fe-Mn carbonate halos indicate significant hydrothermal fluid volumes that have interacted with the sea-floor and subsea-floor sediments. These halos provide an important vector for exploration. Basin-scale, fluid-flow modeling has emphasized the importance of (1) early rift phase volcanic and volcaniclastic rocks as potential deep sources for metals, (2) clastic units at the top of the rift package that act as aquifers for basin-wide hydrothermal fluid flow, (3) evaporitic units that lead to high fluid salinity, which enhances metal transport, (4)
\end{abstract}

†Corresponding author: e-mail, ross.large@utas.edu.au 
thick packages of fine-grained dolomites and siltstones in the overlying sag phase sequence, which act as a seal over the fluid-rich reservoir rocks (rift clastics), and (5) deeply penetrating faults that provide the fluid conduit from the fluid reservoir and metal source area, located deep in the sedimentary basin, to the organic-rich trap rocks at the top of the section. Fluids were oxidized, low- to moderate-temperature $\left(100^{\circ}-250^{\circ} \mathrm{C}\right)$, nearneutral $\mathrm{pH}$ brines, with sulfate reduction in organic-bearing trap sites being the principal cause of zinc- and lead-bearing sulfide deposition.

\section{Introduction}

The Proterozorc Mt. Isa-McArthur basin system of northern Australia (Fig. 1) contains five world-class, stratiform and/or strata-bound, sedimentary rock-hosted $\mathrm{Zn}-\mathrm{Pb}-\mathrm{Ag}$ deposits (Mt. Isa, Hilton, George Fisher, Century, and McArthur River), one world-class strata-bound Ag-Pb-Zn deposit (Cannington), and one world-class sedimentary rockhosted copper deposit (Mt. Isa Copper). There are also numerous smaller or lower grade $\mathrm{Zn}-\mathrm{Pb}-\mathrm{Ag}$ deposits (e.g., Lady Loretta, Dugald River, Grevillea, Walford Creek, Kamarga and Bluebush; Fig. 1; Table 1). The stratiform $\mathrm{Zn}-\mathrm{Pb}-\mathrm{Ag}$ deposits occur in sedimentary rocks that range in age from 1670 to $1580 \mathrm{Ma}$, with the mineralizing events having occurred within at least three discrete time intervals. Metamorphic grade of the host sedimentary rocks varies from subgreenschist facies for the northernmost deposits (McArthur River and Century), through greenschist facies for the central deposits (Lady Loretta, Mt. Isa, Hilton, George Fisher), to amphibolite facies for deposits to the southeast (Cannington). Consequently, the ores are also metamorphosed to various degrees. With increasing metamorphic grade, there is an

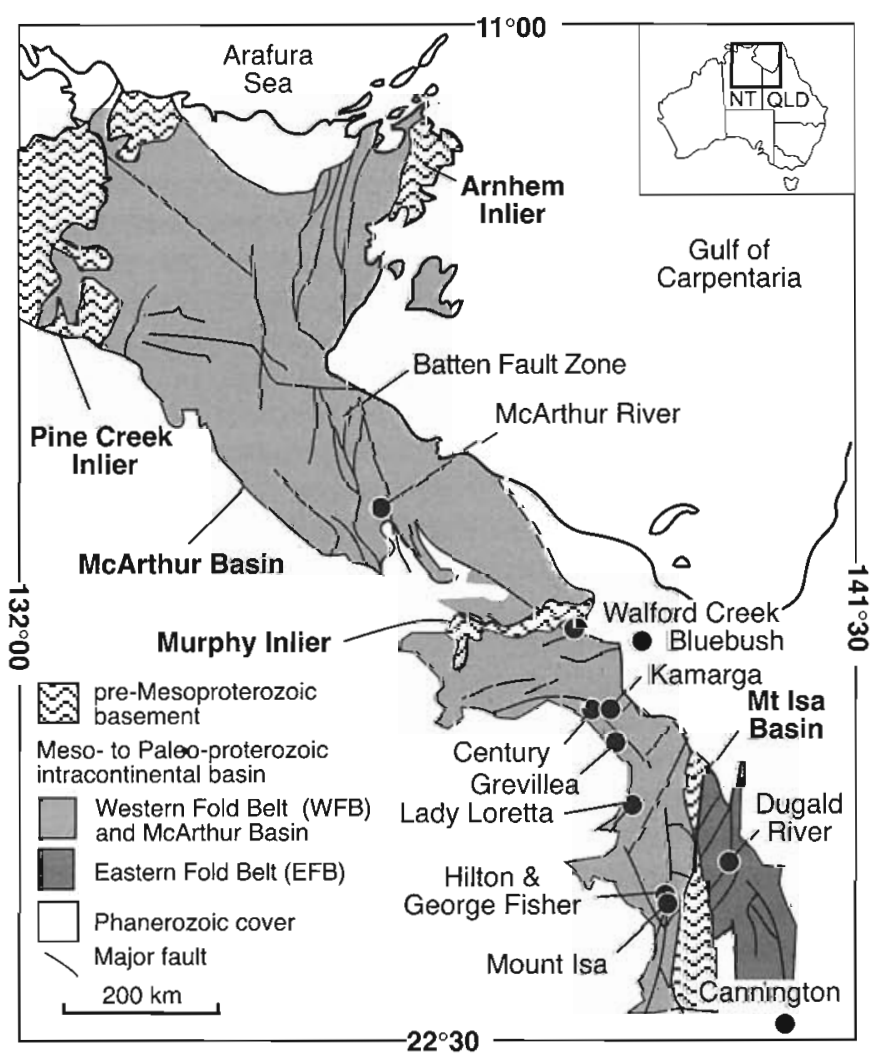

FIG. 1. Regional geology of the Mt. Isa-McArthur basin system with locations of stratiform $\mathrm{Zn}-\mathrm{Pb}-\mathrm{Ag}$ and strata-bound $\mathrm{Ag}-\mathrm{Pb}-\mathrm{Zn}$ deposits. increase in sulfide grain size due to recystallization and remobilization of the ores accompanying deformation and metamorphism. Primary depositional textures are only observed in the least metamorphosed deposits, a factor which has complicated the development of coherent genetic interpretations that can be systematically applied to all deposits.

\section{General features of the $\mathrm{Zn}$ - $\mathrm{Pb}$-Ag deposits}

The five major stratiform $\mathrm{Zn}-\mathrm{Pb}-\mathrm{Ag}$ deposits (McArthur River, Century, Mt. Isa, Hilton and George Fisher) are generally classified as sedimentary exhalative (SEDEX) deposits (Carne and Cathro, 1982; Leach et al., 2005), despite it being generally accepted that not all such SEDEX deposits have necessarily formed by sedimentary-exhalative processes, as discussed below.

The major defining features of the northern Australian stratiform SEDEX deposits discussed by previous workers (Gustafson and Williams, 1981; Solomon and Groves, 2000; Large et al., 2004) are (1) laminated, bedding-parallel, sphalerite- and galena-rich siltstones (Fig. 2a-c), (2) a series of stacked ore lenses separated by pyritic and carbonaceous siltstones and shales (Fig. 3), (3) fine-grained organic-bearing siliciclastic siltstones and shales, which may vary from strongly to weakly dolomitic, host the ores, (4) orebodies are located adjacent to major basin-scale faults that acted as fluid conduits (Figs. 1, 3), and (5) composite alteration halos of pyrite and iron-manganese carbonate in siltstones ( $\mathrm{Mn}$ siderite or Fe-Mn dolomite). Compared to the SEDEX deposits from the Selwyn and Belt-Purcell basins in northwestern North America (Goodfellow et al., 1993; Lydon, 2004), the northern Australian deposits conspicuously lack footwall stringer zones or vent complexes. On this basis, they have been termed vent-distal deposits by Sangster (2002).

The Cannington deposit, situated at the southern end of the Mt. Isa basin, is a strata-bound, rather than stratiform, sedimentary rock-hosted Ag- $\mathrm{Pb}-\mathrm{Zn}$ deposit, which shows significant differences from the other five deposits, and has been termed a Broken Hill-type deposit (Bodon, 1998; Walters and Bailey, 1998; Walters et al., 2002). The Broken Hill-type deposits differ from the northern Australian SEDEX deposits in the following ways (Table 2; Beeson, 1990; Large et al., 1996; Walters, 1996): (1) occurrence in high-grade metamorphic rocks, (2) lack of finely laminated, bedding-parallel sulfide mineral textures, (3) lack of organic-rich siltstones and a more oxidized siliciclastic sedimentary rock host package, (4) very high concentrations of manganese, which is particularly enriched in spessartine garnet, along with $\mathrm{P}, \mathrm{F}$, and rare earth elements (REE), (5) a magnetite association, either within, or along strike from, ore, and (6) presence of a semiregional, garnet-bearing, alteration halo.

Tonnage-grade data outlined in Table 1 are plotted in Figure 4 to show a comparison of the northern Australian Proterozoic $\mathrm{Zn}-\mathrm{Pb}-\mathrm{Ag}$ deposits with other major stratiform 

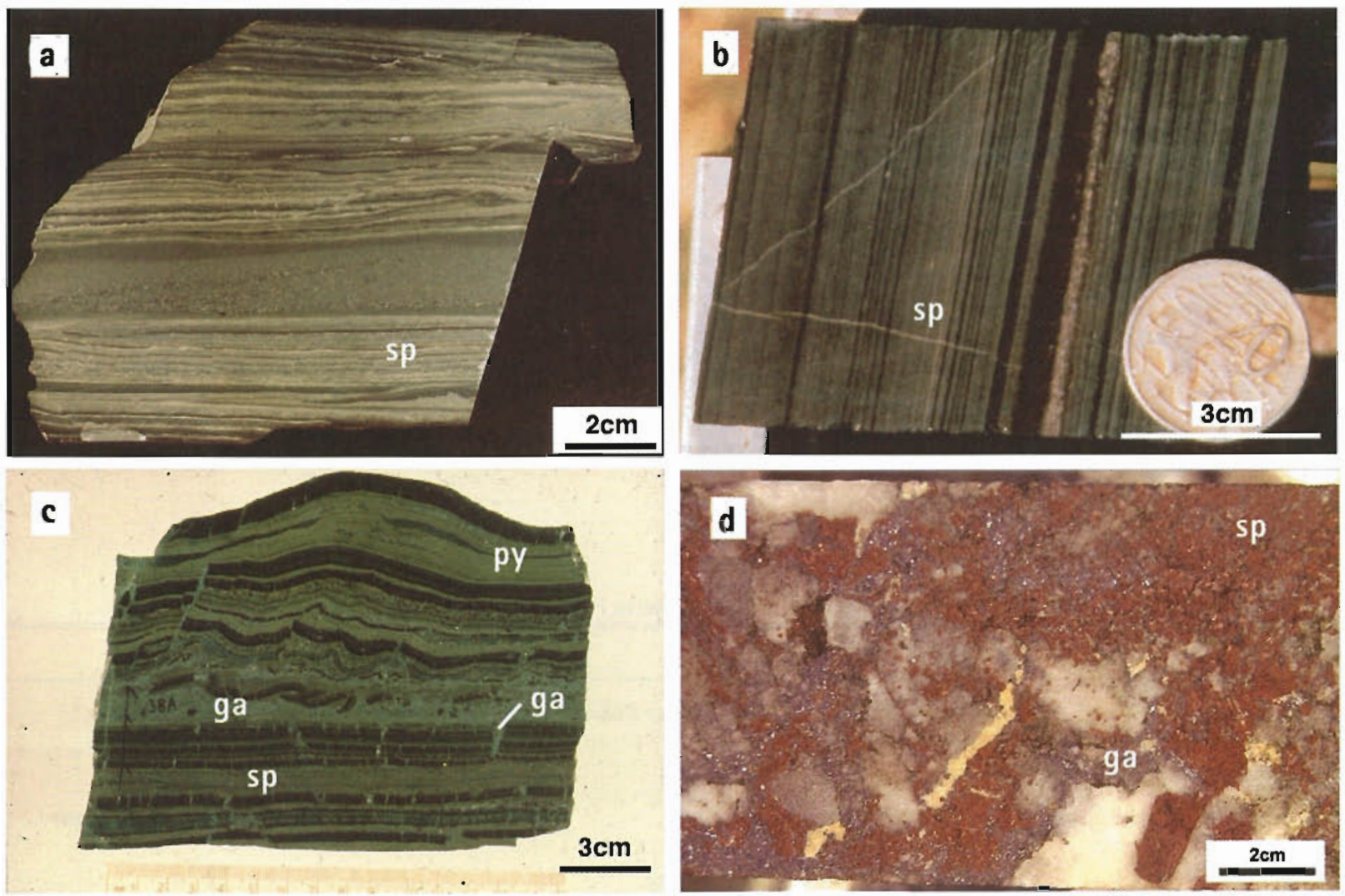

FIG 2. Typical hand specimen samples of $\mathrm{Zn}-\mathrm{Pb}$-Ag ore. a. McArthur River sample from orebody 2. Light gray bands are sphalerite-galena, darker gray bands are siltstone-mudstone, with the darkest bands having higher organic content. b. Century ore, light gray bands are sphalerite-rich, black bands are organic-rich siltstone. c. Mt. Isa ore, lighter colored bands are sulfide-rich, black bands are organic-bearing siltstone bands: ga = galena-rich py = pyrite-rich, $\mathrm{sp}=$ sphalerite-rich. Note the remobilization of galena into crosscutting fractures associated with deformation. d. Cannington ore from Glenholm lens. Coarse sphalerite (brown), galena (gray) with quartz (white) showing a diffuse breccia texture.

and/or strata-bound deposits worldwide. Although Red Dog (Alaska, United Stares) and Broken Hill (NSW, Australia) stand out as the largest and highest grade of all, the five northern Australian deposits form a cluster in the supergiant field defined by Singer (1995), with an average size of 100 million metric tons $(\mathrm{Mt})$ and average grade of $15.6 \mathrm{wt}$ percent $\mathrm{Zn}+\mathrm{Pb}$ (Large et al., 2002). Based on total metal endowment for stratiform $\mathrm{Zn}+\mathrm{Pb}$, the $\mathrm{Mt}$. Isa-McArthur basin system ranks number one in the world and contains $111 \mathrm{Mt}$ of $\mathrm{Zn}+$ $\mathrm{Pb}$ metal.

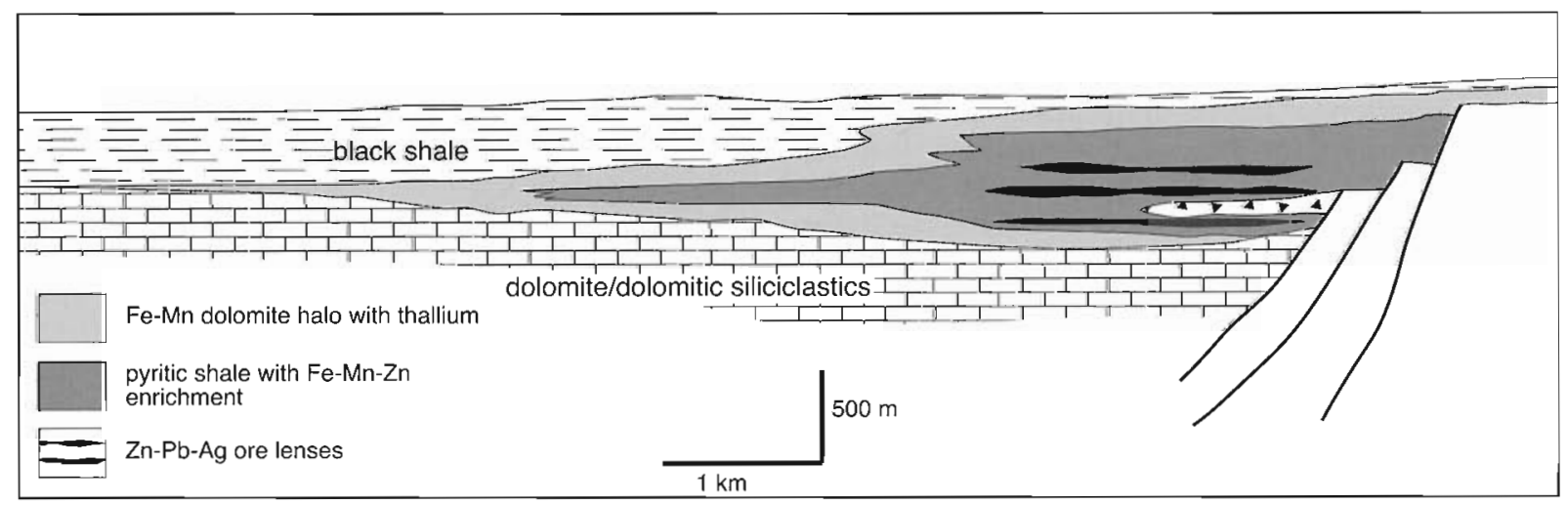

FIG 3. Schematic geologic cross section of a typical Proterozoic northern Australian stratiform Zn-Pb-Ag deposit, showing stacked ore lenses and the related carbonate alteration halo adjacent to a synsedimentary fault system that focused metalliferous brine upflow. 
TABLE 1. Summary of Resources of Zn-Pb-Ag Deposits and Prospects, Northern Australia Proterozoic Basins

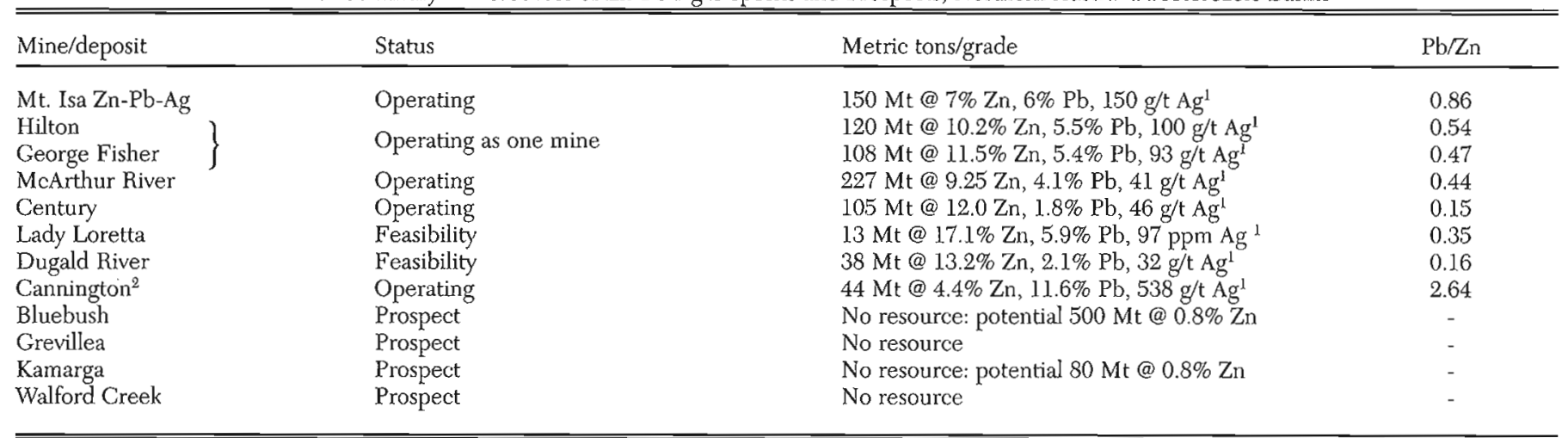

${ }_{1}$ Large et al. (2002)

${ }^{2}$ Cannington is a $\mathrm{Ag}-\mathrm{Pb}-\mathrm{Zn}$ Broken Hill-type deposit

TABLE 2. Comparison of the Major Characteristics of Australian Proterozoic SEDEX and Broken Hill-Type deposits

\begin{tabular}{|c|c|c|}
\hline Examples & $\begin{array}{l}\text { McArthur River, Mt. Isa, Hilton, George Fisher, } \\
\text { Century, Lady Loretta }\end{array}$ & Broken Hill, Cannington \\
\hline Host rock sequence & Black shales, carbonates & $\begin{array}{l}\text { Metashales, sandstones, bif, metavolcanics, } \\
\text { amphibolites }\end{array}$ \\
\hline Pyrite abundance & Minor to major; commonly py > sp, ga & Minor; commonly sp, ga > py \\
\hline Magnetite abundance & Nil to minor & Minor to major \\
\hline Element association & $\mathrm{Mg}, \mathrm{Fe}, \mathrm{Ba}, \mathrm{Mn}, \mathrm{CO}_{2}, \mathrm{Tl}$ & $\mathrm{Ca}, \mathrm{Fe}, \mathrm{Mn}, \mathrm{Si}, \mathrm{P}, \mathrm{F}$ \\
\hline Halo surrounding orebody & Disseminated and stratiform pyrite, $\mathrm{Fe}-\mathrm{Mn}$ carbonate & Mn garnet spotting in meta sediments and volcanics \\
\hline Ore fluid redox state & Relatively oxidized $\mathrm{SO}_{4}^{2-}>\mathrm{H}_{2} \mathrm{~S}$ & Relatively reduced $\mathrm{H}_{2} \mathrm{~S}>\mathrm{SO}_{4}^{2-}$ \\
\hline
\end{tabular}

\section{History of genetic ideas}

There has been considerable debate in the literature over the past 80 years concerning the timing and processes of sulfide mineral deposition for the northern Australian $\mathrm{Zn}-\mathrm{Pb}-\mathrm{Ag}$ deposits. Even though these deposits have the gross features of typical sedimentary rocks, there are many researchers who suggest that the ores formed by replacement along particular sedimentary layers. In fact, the history of research in this world-class base metal province provides a clear example of how genetic ideas can wax and wane with time. Prior to the 1960s, hydrothermal replacement ideas were dominant (Grondijis and Schouten, 1937; Blanchard and Hall, 1942); from the 1960s to late 1970s, synsedimentary exhalative models prevailed (Murray, 1961; Stanton, 1962; Croxford and Jephcott, 1972; Mathias and Clark, 1975; Lambert, 1976); and from then to the mid-1990s syndiagenetic replacement ideas gained the ascendancy (Williams, 1978a, b; Neudert,
1983; Eldridge et al., 1993; Hinman, 1996). Most recently, a complete range of genetic ideas, from syntectonic replacement to syngenetic exhalative, have been published (Perkins, 1997; Broadbent et al., 1998, 2002; Large et al., 1998, 2001a; Perkins and Bell, 1998; Ireland et al., 2004a, b). A theme of this review is to document the critical features and data on the deposits that relate to ore genesis ideas and to evaluate the various genetic models on a deposit-by-deposit basis across this region of northern Australia.

\section{Discovery History and Exploration Techniques}

Although the emphasis in this paper is on the characteristics of the ore deposits and their genesis, a section is included on discovery and exploration techniques, because of their relevance to the discovery of new deposits in this world-class province and in other less well-explored sedimentary basins. With advancing technology, it is likely that the techniques of 


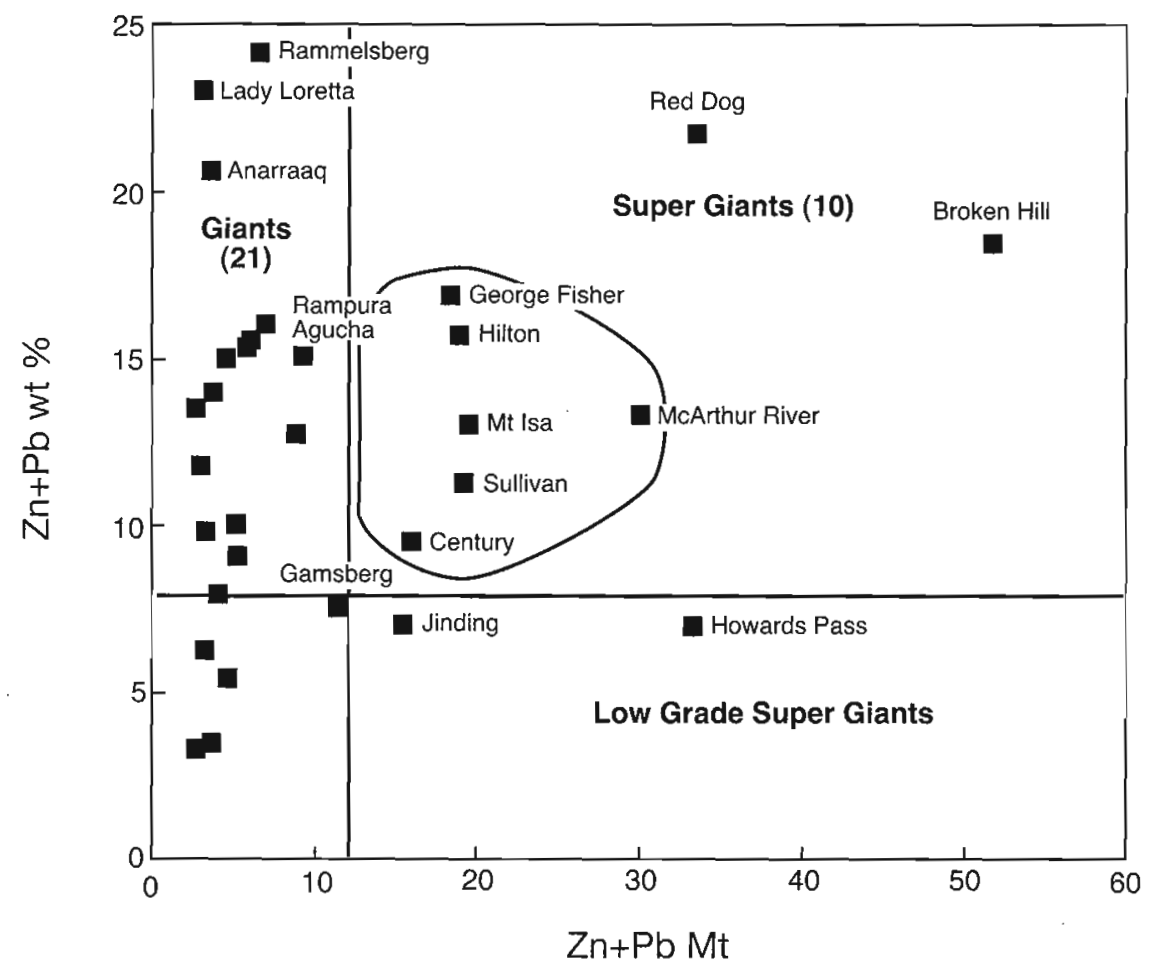

FIG 4. Tonnage-grade plot for 40 stratiform and/or strata-bound sedimentary rock-hosted $\mathrm{Zn}-\mathrm{Pb}$-Ag deposits (modified from Large et al., 2002).

past discovery in well-exposed terranes, such as much of the Mt. Isa-McArthur basin system, will play a lesser role in the current and future frontiers of mineral exploration under cover; nevertheless, although the major Century deposit cropped out, it remained undiscovered until the last decade, despite the application of advanced techniques.

Discovery of sedimentary rock-hosted $\mathrm{Zn}-\mathrm{Pb}$-Ag deposits in northern Australia occurred from the 1880 s to the present (App. Fig. AI). They were found by accident by curious prospectors investigating massive gossans adjacent to welltravelled tracks of the day (e.g., Mt. Isa), as well as by drilling a bullseye magnetic anomaly located $40 \mathrm{~m}$ beneath the main road between Cloncurry and Boulia and intersecting ore with the first hole (Cannington). As summarized in Figure Al, the recognition and drilling of gossans was important to four of the major discoveries (Dugald River, Mt. Isa, Hilton, and McArthur River), and soil geochemistry targeted in favorable stratigraphy led to two major discoveries (Lady Loretta and Century), whereas application of geophysics was critical in the discovery of only the Cannington deposit.

The identification and drilling of gossans (Blanchard and Hall, 1942) played a key role in the discoveries of the Mt. Isa, McArthur River, Hilton, and Dugald River deposits. Throughout northem Australia, the depth of oxidation is variable, ranging from only a few meters (e.g., McArthur River) to $>100 \mathrm{~m}$ (e.g., Lady Loretta). Gossan profiles are affected by local landscape evolution and erosion and by ore, gangue, and host-rock mineralogy. The combination of high pyrite content and a moderate to deep weathering profile led to the prominent gossans at Mt. Isa and Dugald River. However, some $\mathrm{Zn}-\mathrm{Pb}-\mathrm{Ag}$ deposits with a low pyrite content (e.g., Century) did not develop typical gossan outcrops and thus remained undetected until very recently.

In the Mt. Isa deposit, zinc in gossans is consistently in the range of 1,000 to $8,000 \mathrm{ppm}$ (mean $=6,800 \mathrm{ppm} \mathrm{Zn}$ ), whereas at Lady Loretta the gossan has a mean concentration of 82 ppm $\mathrm{Zn}$, which suggests that leaching of zinc is almost complete (Taylor and Thornber, 1992). Taylor and Thornber (1992) showed that indicator elements for sedimentary rockhosted deposits (SEDEX and Broken Hill-type) include not only $\mathrm{Pb}, \mathrm{Zn}$, and $\mathrm{Ag}$, but also $\mathrm{As}, \mathrm{Ba}, \mathrm{Cd}, \mathrm{Cu}, \mathrm{Hg}, \mathrm{Sb}$, and $\mathrm{Tl}$, with less consistently anomalous $\mathrm{B}, \mathrm{Bi}, \mathrm{Co}, \mathrm{Ga}, \mathrm{Ge}, \mathrm{In}$, and $\mathrm{Ni}$. Phosphorous is also anomalous in gossans associated with Broken Hill-type deposits (Taylor and Scott, 1982). As a general rule, lead is significantly less mobile than zinc in the surface environment (Taylor and Scott, 1982) and thus high lead concentrations in gossans are of considerable help in distinguishing prospective gossans from barren ironstones. Galena may oxidize before chalcopyrite and sphalerite, but in arid conditions galena may be preserved as small grains due to coatings of sulfates and carbonates (Blanchard and Hall, 1942; Carter et al., 1961). Lead may combine with P, As, and other elements to form a range of less soluble compounds, such as plumbogummite, beudantite, anglesite, and cerussite (e.g., Mt. Isa gossan). Zinc, if not completely leached, will be present as mainly hemimorphite and smithsonite (e.g., McArthur River gossan), whereas silver is commonly present as native silver and cerargyrite (Carter et al., 1961). Taylor and Scott (1982) found that, overall, stepwise discriminant analysis using $\mathrm{Pb}, \mathrm{P}, \mathrm{Ba}, \mathrm{As}, \mathrm{Zn}, \mathrm{Mn}, \mathrm{S}$, $\mathrm{Co}$, and $\mathrm{Sb}$ could 
classify all ironstones and gossans in the Mt. Isa district into barren and fertile groupings. Scattergrams of $\mathrm{Pb}$ versus $\mathrm{Ba}$ and $\mathrm{Pb}$ versus $\mathrm{Cu}$ (Taylor and Scott, 1982) effectively discriminated all known gossans and ironstones into identifiable groups, and such discriminant analysis has been widely applied in northern Australia in the search for base metal deposits for the past 25 years.

\section{Sedimentary Basin Architecture and Tectonic Setting}

The Mt. Isa-McArthur basin system (Fig. 1) is part of the Northern Australian platform cover, a 5- to 15 -km-thick volcanic and sedimentary rock succession deposited between $\sim 1800$ and $1580 \mathrm{Ma}$ (Jackson et al., 2000; Page et al., 2000). The two constituent basins were probably not physically linked, because basement blocks such as the Murphy Tectonic Ridge separated them (Leaman, 1998). Nevertheless, the stratigraphies of the two basins are broadly correlative, which indicates a shared uplift and/or subsidence history (Fig. 5). The exception is the eastern part of the Mt. Isa basin, informally termed the Eastern fold belt (or succession), where increasing metamorphic and structural grade make correlations unclear. The most recent stratigraphic correlation scheme of Jackson et al. (2000) is applicable throughout the Mt. IsaMcArthur basin system except for the Eastern fold belt. The correlation is based on sequence stratigraphic analysis of the basin fill, U-Pb zircon ages by ion microprobe (SHRIMP), and geochemical and palaeomagentic data, and proposes subdivision of the system into four superbasins, defined as contemporaneous depositional and structural events recognizable across various, now unconnected basin remnants (Scott et al., 1998). The Leichhardt (ca. 1800-1750 Ma), Calvert (ca. 1735-1690 Ma), and Isa (ca. 1670-1580) superbasins (Fig. 5) are nested basin systems in the sense that, although separated by substantial gaps in the stratigraphic record that correspond to basin inversions (e.g., Bull and Rogers, 1996; Scott et al., 1998), each superbasin shares many of the same controlling structures. Sedimentation was terminated during the 1590 to $1500 \mathrm{Ma}$ Isan orogeny (Blake, 1987), which was followed by deposition of rocks of the youngest Roper superbasin. The Isa superbasin hosts all the known stratiform $\mathrm{Zn}-\mathrm{Pb}$-Ag deposits.

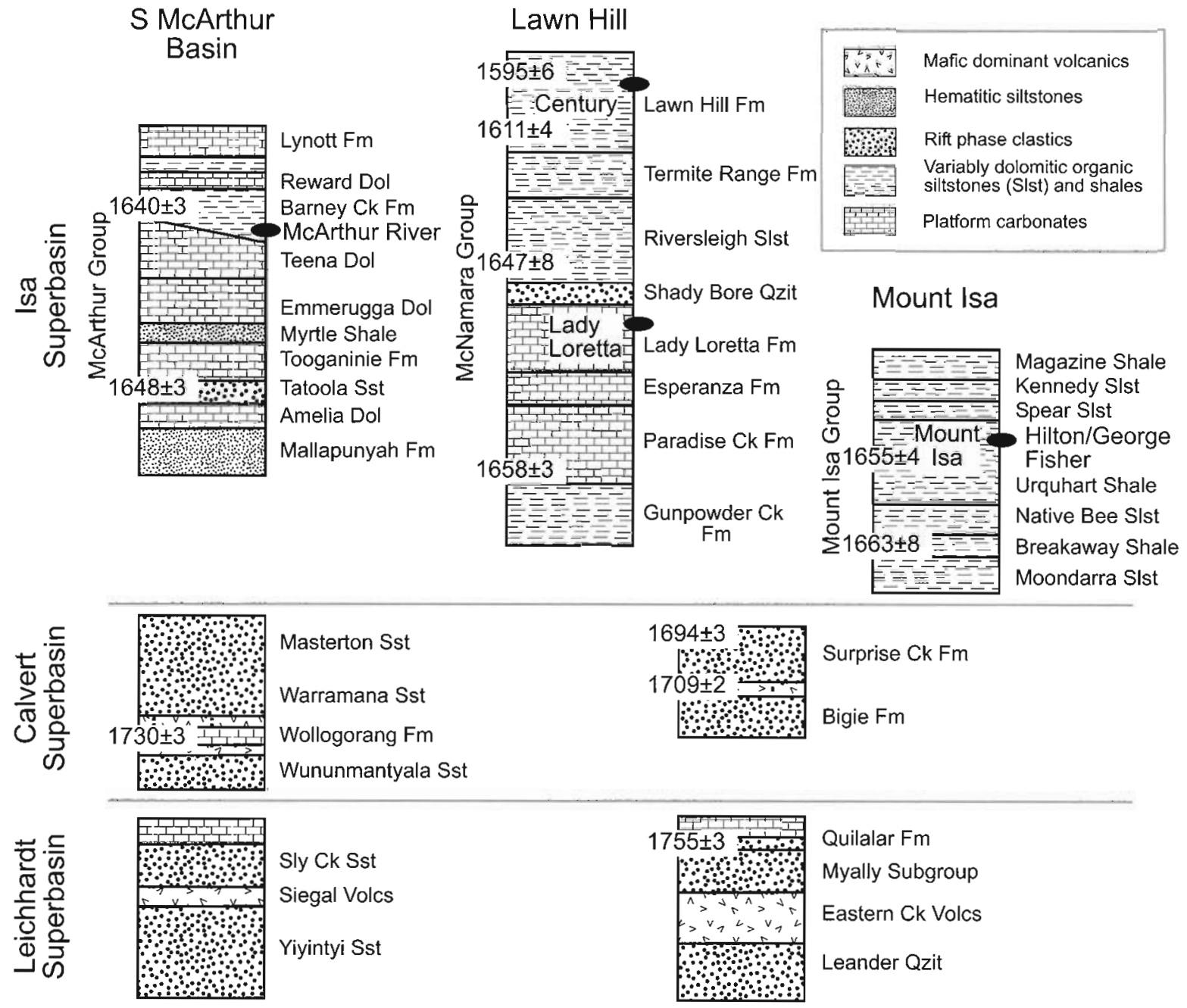

FIC 5. Schematic comparative stratigraphy of McArthur and Mt. Isa basins, showing the position of the major stratiform $\mathrm{Zn}-\mathrm{Pb}$-Ag deposits (selected SHRIMP U-Pb zircon ages after Page et al., 2000). 


\section{Tectonic setting}

The Leichhardt, Calvert, and Isa superbasins record discrete periods of tectonically generated sedimentation that, in the case of all but the Isa superbasin, was accompanied by substantial volcanic and intrusive activity. These events have been widely interpreted in terms of intracontinental rift-sag cycles on the basis of accompanying bimodal volcanism and distinct half-graben geometries for some elements of the basin fill (e.g., Blake, 1987; Eriksson et al., 1993; Betts and Lister, 2001). These models imply continent-scale extension, with recent interpretations suggesting a far-field backarc setting associated with a subduction zone to the south (Giles et al., 2002; Betts et al., 2003; Fig. 6). Scott et al. (2000) used the same architecture but argue for basin formation in response to a mainly convergent regional setting. Their interpretation is based on the recognition of a temporal coincidence between deposition of the superbasin sequences in northern Australia and occurrence of orogenic events in central Australia, interpreted to record terrane accretion along a southern convergent margin (Collins and Shaw, 1995). In this model, periods of subduction produced regional tilting of the craton and periods of accretion and orogeny generated compressive intraplate stresses resulting in regional flexure and strike-slip deformation. These processes combined to produce the Isa superbasin, which is comprised of a combination of aerially extensive platforms and ramps (e.g., Sami et al., 2000), yet aerially restricted, fault-bounded, strike-slip basins (e.g., Southgate et al., 2000; Selley et al., 2001).
Intrabasinal structural and stratigraphic setting of the deposits

All the stratiform $\mathrm{Zn}-\mathrm{Pb}-\mathrm{Ag}$ deposits share two characteristics; they are hosted in reduced, fine-grained lithologies in the Isa superbasin, and they are situated adjacent to regionalscale, north- to northwest-trending faults (Fig. 1, App. Fig. A2). Therefore, the historical studies on deposit settings have focused on the depositional environment of the reduced sediments and the relationship between their depocenters and the regional fault network (i.e., presence of cross faults, as shown in Figure A2, and development of sub-basins). Examples include: (1) the work of Muir (1983), who interpreted the host succession at McArthur River as a restricted evaporitic sabkha, (2) Broadbent et al. (1998) who interpreted the Century deposit to have formed in a sub-basin adjacent to the Termite Range fault, and (3) the work of Large (1983), who emphasised the worldwide importance of second- and thirdorder sub-basins within first-order shale basins as sites for metal accumulation.

The Cannington Broken Hill-type deposit occurs in upper amphibolite facies rocks making the tectono-stratigraphic setting more difficult to determine. The host succession, the Gandry Dam Gneiss, has a maximum depositional age of $1676 \pm 5 \mathrm{Ma}$ (Page and Sun, 1998), which corresponds with a period of depositional hiatus (1694-1668 Ma) and felsic magmatism at the base of the Isa superbasin. Beardsmore et al. (1988) interpreted that the protolith for the gneiss represents an immature basal rift phase comprising sandstones, siltstones, volcaniclastic rocks, bimodal volcanic rocks, and

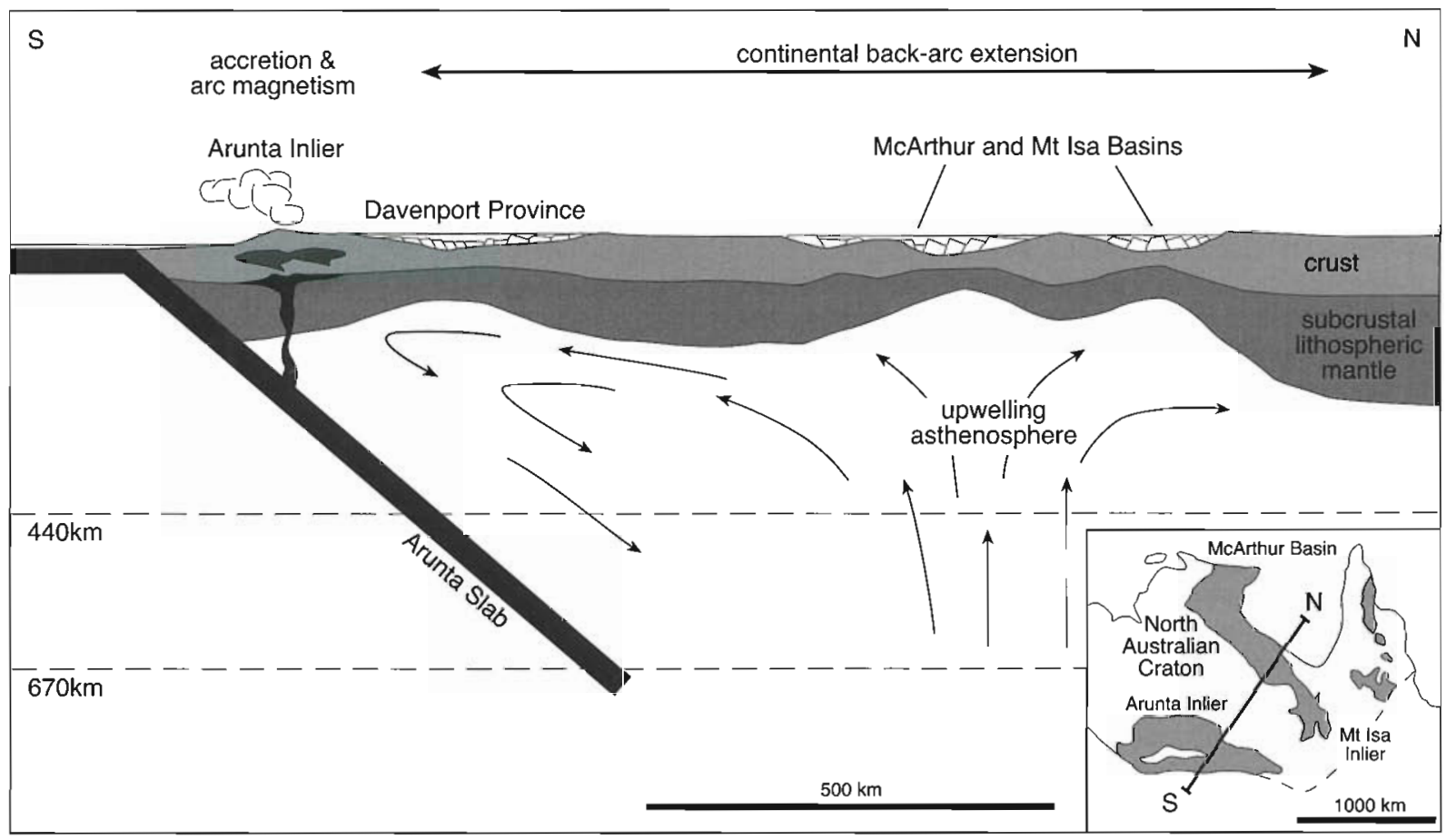

FIG 6. Lithospheric-scale cartoon showing a tectonic model for the development of the Mt. Isa and McArthur basins. Extensional basins are developed in the overriding plate related to a north-dipping subduction zone along the southern margin of the craton (from Betts et al., 2003). 
minor ironstones deposited at shallow to moderate water depths.

The fine-grained, reduced host rocks to the stratiform $\mathrm{Zn}$ $\mathrm{Pb}-\mathrm{Ag}$ deposits were deposited in a range of sedimentological environments with varying degrees of local structural control. For example, the host rocks to the Lady Loretta deposit were deposited in a restricted lagoonal setting (Dunster, 1996), whereas the McArthur River deposit host rocks record quiet, sub-wave base conditions (Bull, 1998). The host rocks for the Century deposit were deposited in similar sub-wave base parts of an outer shelf to deeper water environment (Andrews, 1998). This is also the current favored model for the host rocks to the Mt. Isa, Hilton, and George Fisher deposits (Domagala et al., 2000).

McArthur River is the only deposit hosted in sedimentary rocks that were clearly deposited in a restricted, faultbounded sub-basin. This is evidenced by the rapid eastward change in thickness $(<200->1,000 \mathrm{~m}$ over $15 \mathrm{~km})$, change in facies from shallow-water carbonate-rich facies to subwave base siltstones toward the Emu fault zone (Large et al., 1998), and by the interore breccia beds that record structural exhumation of underlying strata (Walker et al., 1977; Large et al., 1998). At Century, basin reconstruction is hampered because all of the margins of the orebody are either faults or erosional unconformities (Broadbent, 1998) and the host sedimentary rocks do not crop out within 10 to $15 \mathrm{~km}$ of the deposit. However, Broadbent et al. (1998) nonetheless interpret a sub-basin setting. In contrast to the McArthur River deposit, the topographic depression was subdued at Century, because regional changes in thickness of the host strata are less pronounced $\left(100-300 \mathrm{~m}\right.$ ) over the $>15-\mathrm{km}^{2}$ deposit area (Andrews, 1998; Bull, 2001). There are also no McArthur River-type interore breccias that indicate active local displacement on the adjacent Termite Range fault. The current model for the setting of the rocks of the McNamara Group, which host the Mt. Isa, Hilton, and George Fisher deposits, is that they represent the deeper end of a broad southeast-facing ramp, in an area of dilatancy caused by strike-slip activity on north- to northeast-trending faults (Southgate et al., 2000). Derrick (1982) provided evidence for proposed synsedimentary growth faulting in the shale hosting the Mt. Isa deposit. This included changes in sediment thickness across the Transmitter fault in the Hilton deposit area, but Valenta (1994) interpreted these thickness changes as due to postsedimentation deformation. Nevertheless, there is convincing evidence of synsedimentary growth faulting deep in the footwall stratigraphy at both the Hilton and Mt. Isa deposits (Derrick, 1996). These pre-ore growth faults are likely sites for later basin-margin reactivation at times of $\mathrm{Zn}-\mathrm{Pb}-\mathrm{Ag}$ mineralization at about 1655 to $1650 \mathrm{Ma}$ at Mt. Isa and Hilton (e.g., Betts and Lister, 2001).

\section{Major Stratiform Ore Deposits}

\section{McArthur River (HYC)}

The McArthur River deposit, previously known as HYC, is the largest of the northern Australian stratiform $\mathrm{Zn}-\mathrm{Pb}-\mathrm{Ag}$ deposits, with a geologic resource of $227 \mathrm{Mt}$ (at 9.2 wt \% $\mathrm{Zn}$, $4.1 \% \mathrm{~Pb}, 0.2 \% \mathrm{Cu}$, and $41 \mathrm{~g} / \mathrm{t} \mathrm{Ag}$; Logan et al., 1990) and a mining resource of $125 \mathrm{Mt}$ (at $13 \mathrm{wt} \% \mathrm{Zn}, 6 \% \mathrm{~Pb}$ and $60 \mathrm{~g} / \mathrm{t}$
Ag; D. Nihill, oral commun., 2002). Because of its large size and lack of significant metamorphism, the deposit has been the subject of considerable research in an attempt to understand the sulfide mineral depositional processes in this class of stratiform $\mathrm{Zn}-\mathrm{Pb}-\mathrm{Ag}$ deposits (e.g., Croxford and Jephcott, 1972; Lambert, 1976; Williams, 1978a, b; Eldridge et al., 1993; Large et al., 1998, 2001a; Logan et al., 2001; Ireland et al., 2004a, b). The major focus of debate on the deposit has related to the timing and process of base metal sulfide deposition. Arguments centered on whether exhalative deposition on the basin floor (e.g., Croxford and Jephcott, 1972; Large et al., 1998), or diagenetic replacement and open space fill in the muds below the basin floor (e.g., Williams, 1978a, b; Eldridge et al., 1993; Logan et al., 2001), was the dominant process. Recent studies indicate that both sulfide depositional processes have been important in the development of the ore lenses (Ireland et al., 2004a, b), and that the bulk of the laminated high-grade ore in the center of the deposit formed by exhalative synsedimentary processes, whereas the nodular low-grade ore on the deposit fringes formed by diagenetic replacement in the muds.

Surface expression and discovery history: The McArthur River deposit is located within undulating and dissected hills bordering the Carpentarian coastal plain. Except for two small outcrops, the deposit is obscured by as much as $30 \mathrm{~m}$ of alluvium and black soil. One outcrop, near the V121 shaft, is composed of a gossanous, jaspery breccia, which contains hemimorphite that forms a 5-m-high hill. The other is an isolated outcrop of weathered, laminated, bituminous, and pyritic shale and siltstone in the bank of Barney Creek, about $500 \mathrm{~m}$ to the north (Jackson et al., 1987; Pietsch et al., 1991). In areas of shallow residual soils overlying the ore zone, the soil profile to bedrock is consistently characterized by $>1,000$ ppm $\mathrm{Pb}+\mathrm{Zn}$. In areas of alluvium, geochemical anomalies over the ore zone are less pronounced, with only patchy anomalies that locally are as high as $300 \mathrm{ppm} \mathrm{Pb}$ and 1,800 ppm Zn (Butt and Smith, 1980).

The area around the McArthur River deposit contains numerous vein occurrences of galena, which attracted interest from prospectors as early as 1887 (Jackson et al., 1987). Mt. Isa Mines (MIM) geologists visited some of the galena vein occurrences in 1948, and again in 1954 when Clem Knight, a Consolidated Zinc geologist seconded to MIM (or Carpentaria Exploration Co.) compiled observations on base metal exploration for "bedded"- or syngenetic-type deposits, which he suggested may occur at discrete stratigraphic levels in the district (Knight, 1953). A prospecting and geochemical exploration program commenced in this area in 1955, and Murray (1975) reported that the McArthur River deposit was located by "an inquisitive field assistant," J. Smith, who was conducting a soil geochemical survey across a key section line within a $60-\times 60-\mathrm{km}$ area. He noticed the small jaspery hill mentioned previously and collected samples of the pinkish silica with abundant white acicular crystal masses, later identified as hemimorphite. Continued exploration from 1956 to 1959, including mapping, trenching, soil geochemistry, and finally drilling, led to the discovery. The fine-grained $\mathrm{Zn}-\mathrm{Pb}-\mathrm{Ag}$ mineralization encountered in the bottom of two diamond holes drilled in 1959 was not recognized until a step-out hole was drilled and holes $I$ and 2 were deepened to confirm this 
major discovery (Logan et al., 1990). Although possibly apocryphal, it is said that one member of the exploration team remarked that he had never had the opportunity to name a major discovery. "Well," said another, "here's your chance" (HYC).

Local geology and sedimentology: The deposit lies adjacent to the regionally extensive north- northeast-trending Emu fault system and consists of eight stacked stratiform ore lenses hosted in dolomitic, carbonaceous siltstones at the base of the HYC Pyritic Shale Member of the Barney Creek Formation (Fig. 7). Minor tuff bands in the sequence have been dated by the U/Pb zircon method at $1640 \pm 3 \mathrm{Ma}$ (Carr et al., 1996). Facies and thickness patterns in the HYC pyritic shale indicate sedimentation during an episode of synsedimentary tectonism and that the orebody formed in the deepest part of a sub-basin developed adjacent to the Emu fault.

Interore mass-flow breccias: The ore lenses vary in thickness from 3 to $12 \mathrm{~m}$ and are separated by laterally continuous mass-flow breccias and associated dolomitic siltstones (Fig. 7; Walker et al., 1977; Logan, 1979). The mass flows thicken and become coarser grained to the north and east, indicating that they are sourced from mass wastage along the tectonically active Emu and related Western faults (Logan, 1979; Ireland et al., 2004a). The cyclic relationship between ore lenses, dolomitic carbonaceous siltstones, and mass-flow breccias strongly suggests that the Emu fault system controlled both ore fluid migration and sediment breccia deposition, with mineralization confined to the deepest part of the sub-basin adjacent to the active fault system (e.g., Large et al., 1998). A variety of sulfide mineral clasts occur in the mass-flow breccias (Logan, 1979; Large et al., 1998). Ireland et al. (2004a) have shown the presence of abundant clasts of laminated base metal sulfides, which are identical in texture and composition to the ore lens material, immediately underlying the mass flows. This provides convincing evidence that constrains base metal mineralization at McArthur River to the uppermost level of the sea-floor sediments, where the laminated ores were susceptible to erosion by incoming mass flows.

Sulfide textures and paragenesis: The most striking feature of the ore is the consistent bedding-parallel nature of the base metal sulfide laminations (Fig. 2a). Four major laminae types have been recognized at the millimeter scale: (1) organic-rich mud layers, (2) quartz-illite-carbonate silt layers, (3) zinc-lead sulfide-rich layers, and (4) hybrid laminae that consist of mixtures of the previous three types (Fig. 8a, b; Large et al., 1998). The base metal sulfides are extremely fine grained (typically $<1-10 \mu \mathrm{m}$ ) and complexly intergrown within the laminations. Previous studies have revealed as many as seven sulfide types; two stages of pyrite ( $\mathrm{py}_{1}$ and $\mathrm{py}_{2}$ ), two stages of sphalerite ( $\mathrm{sp}_{1}$ and $\mathrm{sp}_{2}$ ), galena, chalcopyrite, and arsenopyrite (e.g., Croxford and Jephcott, 1972; Williams, 1978a; Eldridge et al., 1993; Large et al., 1998; Ireland et al., 2004b). Paragenetic studies have played a critical role in the interpretation of the precise timing of mineralization relative to sedimentation. It is agreed that the coarser grained py2 generation (Fig. 8c) is diagenetic in origin. However, Williams (1978a) and Eldridge et al. (1993) have interpreted that the base metal sulfides postdate $\mathrm{py}_{2}$ and are, therefore, of epigenetic or diagenetic origin, whereas Croxford and Jephcott (1972), Lambert (1976), and Large et al.

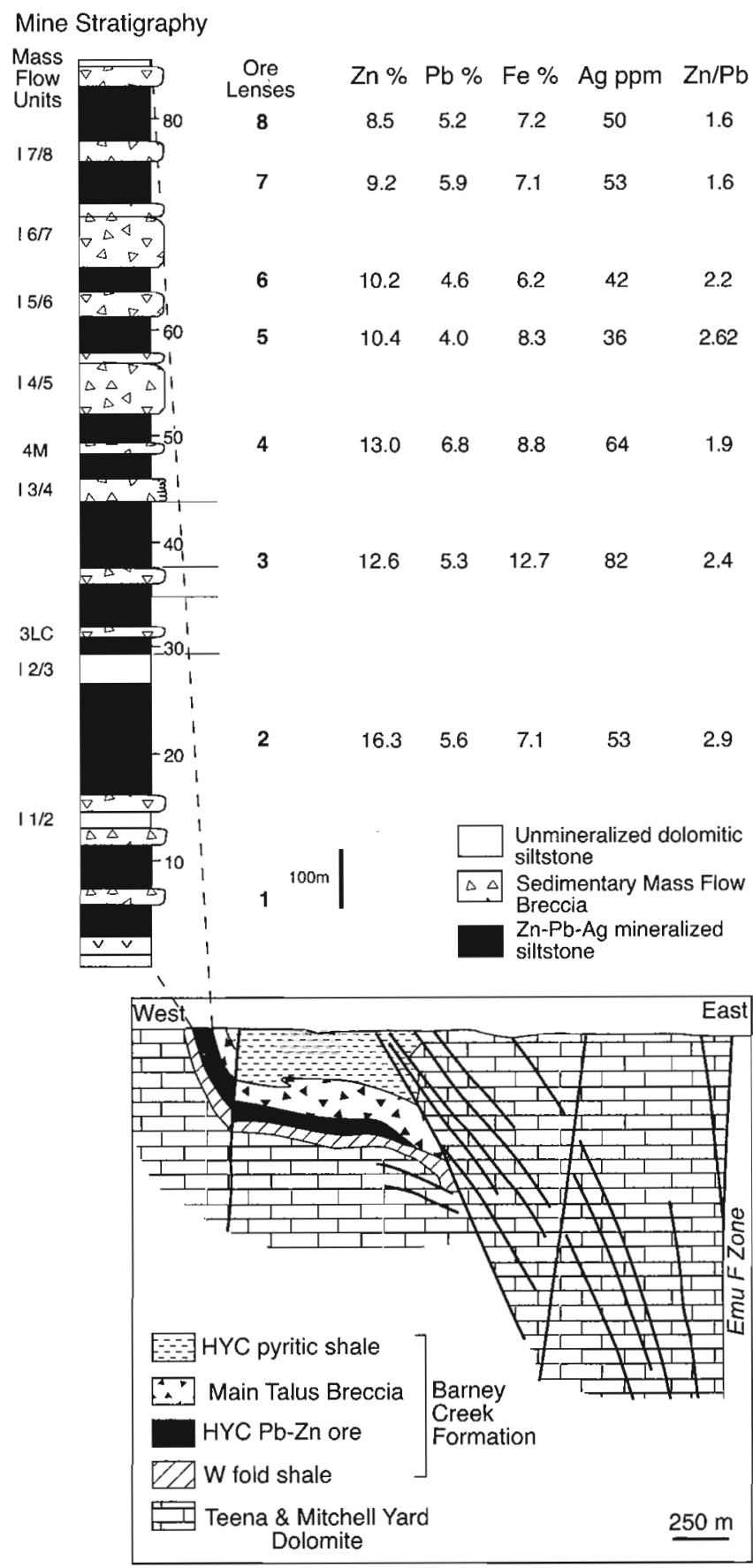

FIG 7. Generalized cross section of the McArthur River $\mathrm{Zn}-\mathrm{Pb}-\mathrm{Ag}$ deposit with stratigraphic column of ore zone, showing the eight separate orebodies with average base metal grades (compiled from Lambert, 1976; Eldridge et al., 1993; Hinman, 1995).

(1998) have considered the bulk of the base metal sulfides to predate py2 and be of syngenetic origin. Recent work by Ireland et al. (2004b), which appears to have resolved this problem, has revealed two texturally and isotopically distinct forms of sphalerite ( $\mathrm{sp}_{1}$ and sp2; Fig. 8a, App. Fig. A3), one of which predates py, and is likely syngenetic (stage 1 ) and the other which postdates pyz and is likely formed by diagenetic replacement (stage 2). There may also be two stages of galena; 

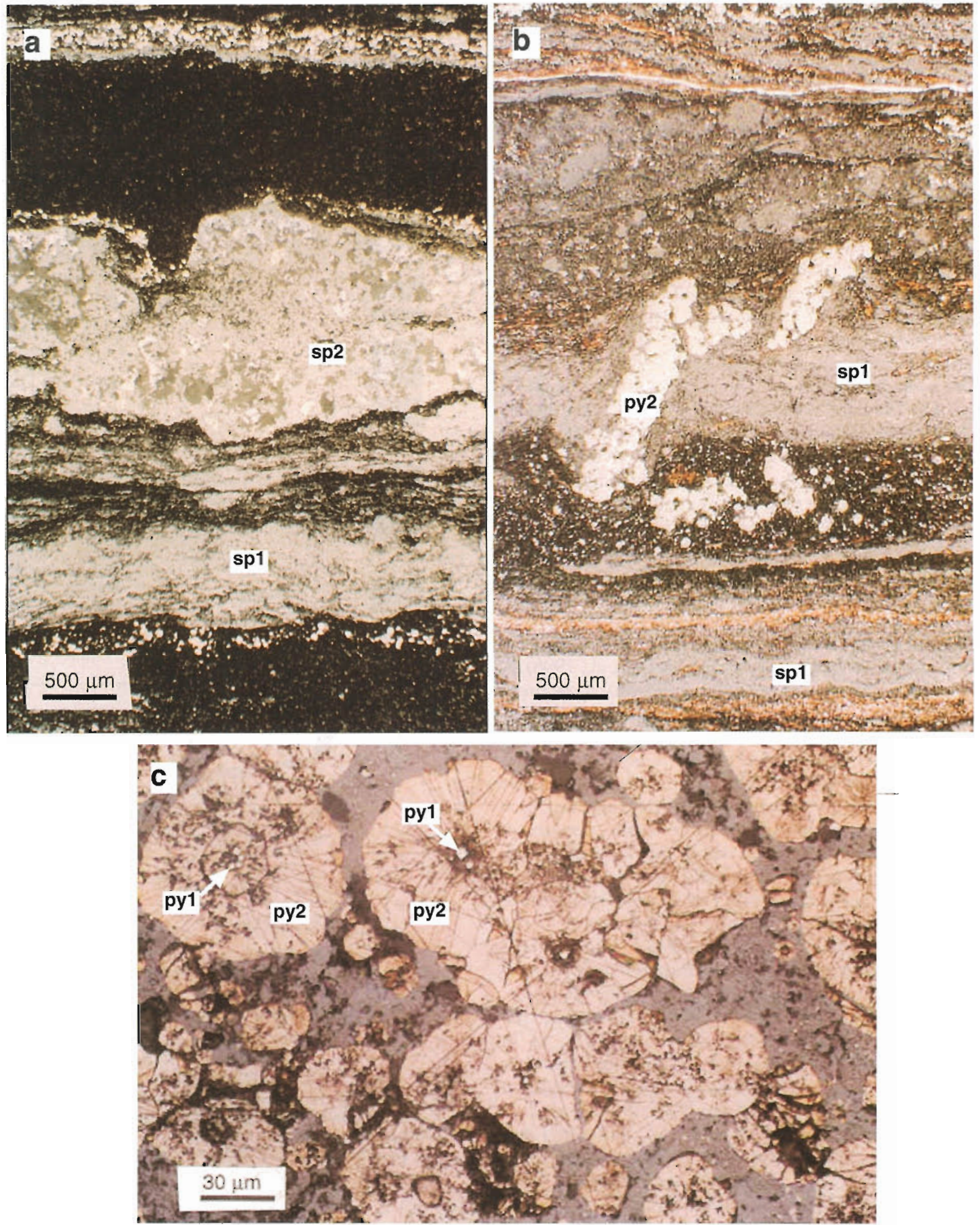

FIG 8. Photomicrographs of ore textures at McArthur River. a. Two types of sphalerite in McArthur River ores: $\mathrm{sp}_{1}$ in finegrained bedding-parallel layers and $\mathrm{sp}_{2}$ intergrown with dolomite in irregular coarser grained nodular layers. b. Diagenetic pyrite aggregate ( $\mathrm{py}_{2}$ ) overgrowing and crosscutting an earlier sphalerite $\left(\mathrm{sp}_{1}\right)$ layer. $c$. pyg nodules overgrowing small pyl crystals (from Large et al., 2002). 
however, they have not been distinguished by either textural or isotopic studies.

Metal relationships, metal zonation, and fluid-flow directions: There is a positive correlation between $\mathrm{Zn}, \mathrm{Pb}, \mathrm{Ag}, \mathrm{Cu}$, and $\mathrm{Cd}$ in the ores, whereas $\mathrm{Fe}, \mathrm{S}$, and $\mathrm{Tl}$ do not correlate strongly with the base metals (Croxford and Jephcott, 1972). This suggests a decoupling of base metals and pyrite in the mineralization process. The average zinc concentration decreases upward from lens $2(16.3 \mathrm{wt} \% \mathrm{Zn}$ ) to lens 8 ( $8.5 \mathrm{wt}$ $\%$ Zn; Fig. 7; Lambert, 1976), suggesting a gradual decrease in the intensity of the hydrothermal system or capacity to transport zinc, with time. The average $\mathrm{Zn} / \mathrm{Pb}$ ratio of the ore lenses decreases in a batchwise fashion from orebodies 2 to 4 $(\mathrm{Zn} / \mathrm{Pb}=2.9-1.9)$ and then from orebodies 5 to $8(\mathrm{Zn} / \mathrm{Pb}=$ 2.6-1.6). This suggests a change in hydrothermal conditions between the lower and the upper orebodies. Logan (1979) observed a lateral zonation of $\mathrm{Cu}$ to $\mathrm{Pb}$ to $\mathrm{Zn}$ to Fe from north to south in the lower orebodies. A similar zonation was reported for the upper orebodies but with a notable shift in orientation from east to west. The lateral zonation has been interpreted to indicate the direction of fluid flow; from north to south in the lower lenses and east to west in the upper lenses. The cause of the zonation may be decreasing temperature laterally away from the fluid entry point into the orebody (Logan et al., 2001), or some other chemical gradient along the fluidflow path (e.g., $\mathrm{pH}$ increase, gradual decrease in $f_{\mathrm{O}_{2}}$, or a chemical kinetic effect; Cooke et al., 1998, 2000). The more lead- and copper-rich ores have been interpreted as proximal to the feeder faults.

Nodular carbonates: The finely laminated nature of mineralized HYC pyritic siltstones grades, on the fringes of the deposit, to globular, blebby, and elongate carbonate aggregates that amalgamate into laterally continuous laminae, locally comprising 50 to $70 \mathrm{vol}$ percent of the siltstone (Logan, 1979; Ireland et al., 2004b). Nodular carbonate laminae are macroscopic aggregates $(1-4 \mathrm{~mm})$ that consist of interlocking anhedral crystalline dolomite grains $(10-140 \mu \mathrm{m})$. Carbonate nodules displace primary siltstone, and stage 1 sphaleritegalena laminae, are variably replaced by $\mathrm{sp}_{2} \pm$ galena (Fig. 8a), and are overprinted by py2, such that the timing of nodule growth is constrained between the precipitation of syngenetic stage 1 and diagenetic stage 2 sulfide phases during early diagenesis (Ireland et al., 2004b). The nodular carbonate is most abundant along the western, northern, and southern fringes of the stacked ore lenses. Although not present along the deformed eastern margin, the carbonate is interpreted by Ireland et al. (2004b) to have completely surrounded the deposit (Fig. 9c). Logan et al. (2001) suggested that the nodules are the distal subsurface expression of lateral fluid flow that formed the $\mathrm{Zn}-\mathrm{Pb}-\mathrm{Ag}$ lenses. In contrast, Ireland et al. (2004b) considered the nodules to have developed

FIC 9. Composite schematic section and plan view of the sub-basin hosting the McArthur River $\mathrm{Zn}$ - $\mathrm{Pb}$-Ag sulfide orebody. a. Schematic cross section showing the $\mathrm{Fe}-\mathrm{Mn}$ carbonate halo extending into the sub-basin to the southwest of the ore deposit. b. Plan view of the subsurface extent of the halo and relationship to major faults. Sedex $\mathrm{AI}$ and $\mathrm{MnOd}$ are alteration indicies defined by Large et al. (2000). c. Plan view of the nodular carbonate and pyritic siltstone envelopes immediately surrounding the stratiform $\mathrm{Zn}-\mathrm{Pb}-\mathrm{Ag}$ orebody (compiled from Large et al., 2000; Ireland et al., 2004b).

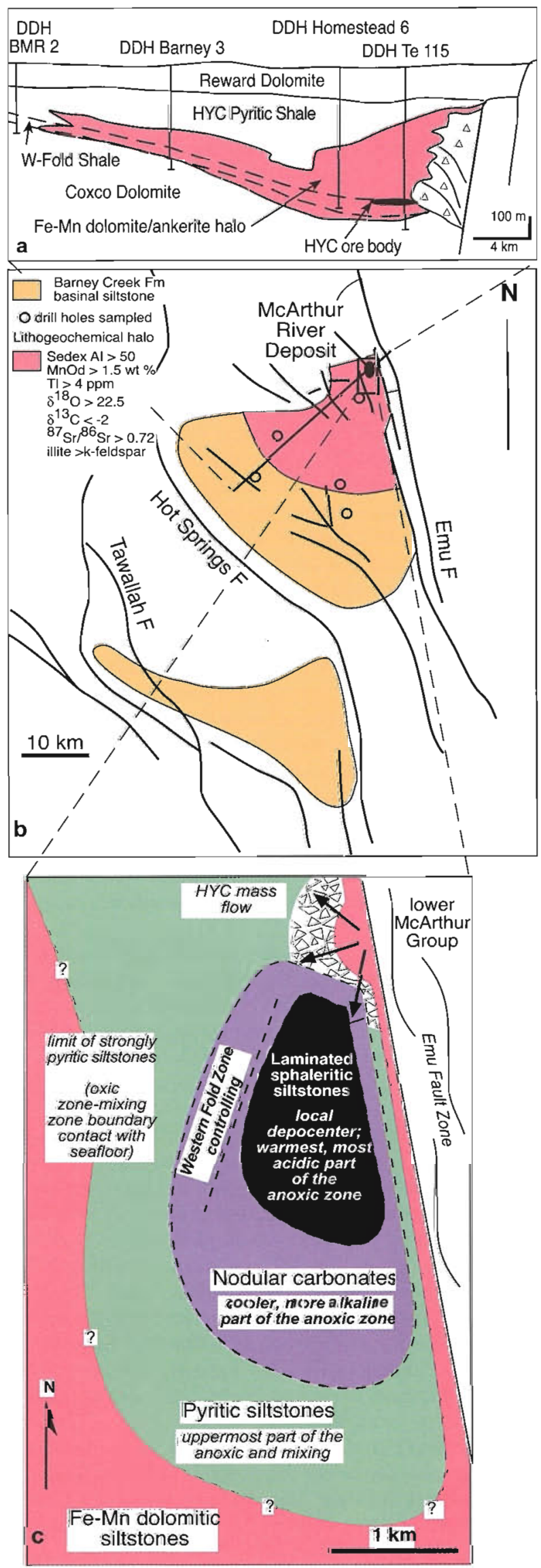


in the muds in a peripheral zone surrounding the laminated ore lenses and to have been controlled by particular physiochemical conditions $\left(\mathrm{pH}, \mathrm{f}_{\mathrm{O}_{2}}, \mathrm{~T}\right.$ ) related to a brine pool ponded in the sub-basin depocenter.

Organic geochemistry and maturation: Studies by Crick et al. (1988) and Crick (1992) indicate anomalously high organic maturation levels in rocks of the Batten trough surrounding the McArthur River deposit, compared to the same McArthur Group rocks regionally. These studies also showed a marked increase in vitrinite reflectance and Rock Eval values adjacent to major faults and within the McArthur River ore lenses. Subsequent work (Logan et al., 2001) has confirmed the higher organic maturation levels in the ore zone compared to the normal burial trend and indicates the interaction between organic matter in the sediments, and/or the water column, with the hydrothermal ore fluids. Sulfur/carbon ratios, degree of pyritization values, and organic biomarker data for the shale lamellae in the HYC pyritic shale and ore zones indicate that the ambient organic-rich black muds and silts were deposited in an anoxic marine environment (Williams, 1978b; Large et al., 1998; Logan et al., 2001). The thin turbidite lamellae throughout the ore zones have different degree of pyritization and organic biomarker characteristics, indicating derivation of the source turbidites in an oxic zone, including the presence of unusual sulfide-oxidizing bacteria (Large et al., 1998; Logan et al., 2001). The presence of both sulfide-reducing and -oxidizing bacteria confined to the mineralized sedimentary rock package enclosing the high-grade orebody 2 at McArthur River may have important implications for the process of mineralization. Recent work on the organic geochemistry of the ores and related organic siltstones by Chen et al. (2003) has revealed a suite of polycyclic aromatic hydrocarbons comparable to those of modern hydrothermal systems, such as those in the Guaymas basin (Simoneit, 1994), and significantly different from those found in conventional oil fields.

Lithogeochemical halo: An extensive lithogeochemical halo surrounds the McArthur River deposit, extending several hundred meters into the hanging wall and for as much as 23 $\mathrm{km}$ along strike to the southwest away from the Emu fault (Fig. 9a, b; Lambert and Scott, 1973; Large et al., 2000, 2001b). The halo consists of two components:

1. A ferroan dolomite + ankerite \pm pyrite halo, with anomalous $\mathrm{Zn}(>1,000 \mathrm{ppm}), \mathrm{Pb}$ (>100 ppm), and $\mathrm{Tl}(>4 \mathrm{ppm})$, extends $250 \mathrm{~m}$ into the hanging-wall sedimentary rocks, as much as $50 \mathrm{~m}$ into the footwall, and as far as $15 \mathrm{~km}$ along the favorable siltstone unit at the base of the HYC pyritic shale (Fig. 9a, b; Large et al., 2000). Carbonate within this halo shows an ${ }^{18} \mathrm{O}$-enriched $\left(\delta^{18} \mathrm{O}>22.5 \%\right)$ and ${ }^{13} \mathrm{C}$-depleted $\left(\delta^{13} \mathrm{C}<-2 \%\right.$ ) isotopic signature compared to regional marine carbonate minerals. The carbonate within the halo also shows a strongly radiogenic strontium isotope signature $\left({ }^{87} \mathrm{Sr} /{ }^{\beta 6} \mathrm{Sr}\right.$ $>0.7200$ ) compared to typical Proterozoic marine carbonate minerals (Large et al., 2001b).

2. High $\mathrm{MnO}$ contents are confined to the sedimentary unit stratigraphically below the orebody (W-Fold Shale Member). This forms the most laterally extensive part of the composite McArthur River deposit halo. The average $\mathrm{MnO}$ content of dolomite within the W-Fold shale increases progressively from $1.5 \mathrm{wt}$ percent $23 \mathrm{~km}$ to the southwest to 11.5 wt percent at the deposit (Fig. 9a). Large et al. (1998, 2001a) have argued that the composite lithogeochemical and isotopic halo relates to a fossil brine pool developed in the deepest part of the HYC sub-basin surrounding the deposit and bounded on the eastern side by the Emu fault. This is supported by the extensive stratigraphic nature of the $\mathrm{Mn}, \mathrm{Tl}$, $\mathrm{Zn}$, and $\mathrm{Pb}$ element and $\mathrm{C}, \mathrm{O}$, and $\mathrm{Sr}$ isotope halos, and their homogenous distribution throughout the fine-grained dolomitic sediments, which are features indicative of synsedimentary halo formation, rather than postsedimentation replacement processes.

Sulfur isotopes: The $\delta^{34} \mathrm{~S}$ values of sulfide minerals in the deposit vary over a wide range from -13 to +45 per mil (App. Figs. A3, A4). Smith and Croxford (1973) showed that both base metal sulfides and pyrite exhibit increasing $\delta^{34} S$ up stratigraphy from orebodies 1 to 8 (base metal sulfides from $\delta^{34} \mathrm{~S}=-3$ to $+9 \%$, pyrite from -3.5 to $+15 \%$ upsection). They proposed that pyrite formed diagenetically by bacterial sulfate reduction in the anoxic muds, whereas the base metal sulfides precipitated from a separate hydrothermal sulfur source entering the basin. Subsequent iron microprobe and laser ablation sulfur isotope analyses (Eldridge et al., 1993; Ireland et al., 2004) have shown that each major paragenetic stage of pyrite and sphalerite has a discrete, but overlapping, sulfur isotope population (Fig. A3). The paragenetically earliest sulfide, py, has the lowest $\delta^{34} S$ values with a mean of -0.1 per mil and a wide range from -13 to +30 per mil. The next sulfide in the paragenesis, $\mathrm{sp}_{1}$, which forms the major laminated ores, has a mean of 3.8 permil and a relatively narrow range from -5 to +15 per mil. The nodular sphalerite, $\mathrm{sp}_{2}$, which formed by diagenetic replacement, has a mean of +9.8 per mil with a range from +3 to +19 per mil. The paragenetically latest sulfide, py, has a mean $\delta^{34} S$ value of +13.1 per mil and a wide range from -5 to +45 per mil. The data are interpreted to indicate that py formed at low temperature in the ambient anoxic water column by biogenic reduction of marine sulfate. The sulfide in $\mathrm{sp}_{1}$ was produced principally by biogenic sulfate reduction (BSR) in a transient pool of warm metalliferous brine fed by pulses of metalliferous fluid (Ireland et al., 2004b). Sulfate reduction kinematics under the temperature and chemical conditions in the brine inhibited sulfur isotope fractionation and caused the isotopic separation of $\mathrm{py}_{1}$ and $\mathrm{sp}_{1}$. The $\mathrm{sp}_{2}$ formed isotopically heavy sulfur by closed-system Rayleigh distillation in the muds below the brine pool, and pyz formed, as the last paragenetic stage, from the remaining Raleigh-distilled heavy sulfur in the sediment pore fluids (Ireland et al., 2004b). A small component of sulfide in the ores may have formed by thermochemical sulfate reduction (TSR), taking place in the hottest parts of the hydrothermal system (Hinman, 1996; Ireland et al., 2004b).

Carbon and oxygen isotopes: Bedded and nodular carbonates in the ore lenses have a distinctly different carbon and oxygen isotope signature compared to the regional marine carbonates in the Barney Creek Formation and McArthur Group (App. Fig. A5; Rye and Williams, 1981; Lindsay and Brasier, 2000; Large et al., 2001a). Least altered marine dolomites in the Barney Creek Formation have values of $\delta^{18} \mathrm{O}$ $=20$ to 23 per mil and $\delta^{13} \mathrm{C}=-2$ to 0 per mil, compared to ore-related carbonates (ankerite and ferroan dolomite) that 
have overlapping, but generally heavier oxygen and lighter carbon values $\left(\delta^{18} \mathrm{O}=21-25 \%\right.$ and $\delta^{13} \mathrm{C}=-3.5$ to $\left.-2 \%\right)$. Rye and Williams (1981) interpreted the linear C-O isotope array of ore-related carbonates to indicate a temperature of formation for the stratiform ores of $120^{\circ}$ to $240^{\circ} \mathrm{C}$ from a very ${ }^{18} \mathrm{O}$ enriched fluid $\left(\delta^{18} \mathrm{O}=\sim 10 \% 0\right)$, whereas Smith (1981) and Large et al. (2001a) interpreted the data to indicate lower carbonate formation temperatures (mostly $40^{\circ}-70^{\circ} \mathrm{C}$ but with ore fluid input temperatures as high as $140^{\circ}-200^{\circ} \mathrm{C}$ ) from a fluid with an isotopic composition slightly heavier than seawater $\left(\delta^{18} \mathrm{O}=\sim 5 \%\right.$ ) .

Lead isotopes: Studies by Gulson (1986) showed that the isotopic composition of the McArthur River ore lenses was homogeneous with a variation of only about 0.1 percent. The McArthur River lead isotope data are plotted in Figure A6a, where they are compared to other stratiform $\mathrm{Zn}-\mathrm{Pb}-\mathrm{Ag}$ deposits from northern Australia. The McArthur River, Mt. Isa, and Century deposits, which occur in the Western fold belt (WFB; Fig. I) lie along a growth curve (denoted HYC-WFB, Fig. A6a) derived from the model of Sun et al. (1994) and Carr et al. (2001) that was modified from an earlier model of Cumming and Richards (1975). The McArthur River deposit has been used as a control for the new Pb-Pb isotope model, as there is excellent zircon SHRIMP control on the age of deposition of the ore-hosting rocks (1640 $\pm 3 \mathrm{Ma}$; Page and Sweet, 1998), and the $\mathrm{Zn}-\mathrm{Pb}-\mathrm{Ag}$ mineralization has been shown to be synchronous with sedimentation (Hinman, 1996; Large et al., 1998).

Recent detailed double-spike lead isotope analyses of the stratiform McArthur River ore lenses through the stratigraphy (Carr et al., 2001) define a signature population with an apparent range in model ages of $1.8 \mathrm{~m} . \mathrm{y}$. The lowest orebody measured has the oldest model age $(1640.8 \pm 0.3 \mathrm{Ma})$, and there is a decrease in the middle sequences to $1639 \pm 0.3 \mathrm{Ma}$, although the highest orebody has an intermediate model age of $1640.2 \pm 0.3 \mathrm{Ma}$. These data suggest that the ore lenses at McArthur River were formed progressively over a period of 0.6 to $1.8 \mathrm{~m} . y$.

Fluid temperature estimates: No fluid inclusions have been found in minerals in the laminated ores due to their finegrained nature; thus, fluid temperature and chemistry are based on estimates from thermodynamic and isotopic modeling. Smith and Croxford (1973) suggested an ore fluid temperature of $100^{\circ}$ to $270^{\circ} \mathrm{C}$ based on sulfur isotope mineral pairs, Rye and Williams (1981) estimated $120^{\circ}$ to $240^{\circ} \mathrm{C}$ based on carbon and oxygen isotopes in ore-related dolomite, and Large et al. (1998) estimated $150^{\circ}$ to $250^{\circ} \mathrm{C}$ based on mineralogical and thermodynamic considerations. Recently, a higher temperature of 250 to $400^{\circ} \mathrm{C}$ has been suggested by Chen et al. (2003), based on the composition and pattern of distribution of hydrocarbons. Although the exhaled hydrothermal fluid was probably in the temperature range of $100^{\circ}$ to $300^{\circ} \mathrm{C}$, the temperature at the site of ore formation, on and immediately below the sea floor, was probably significantly lower than this range. Large et al. (2001a) argued that illite crystallinity ( $\mathrm{IC}=0.43-0.69$ ), vitrinite reflectance (Ro\% $=0.9-2.4)$, and $\mathrm{Ca} / \mathrm{Mg}$ mole ratios $(\mathrm{mol} \% \mathrm{Ca}=52-66)$ in the host dolomitic sediments all indicate that mineralizing temperatures were consistently below $200^{\circ} \mathrm{C}$. Based on the carbon and oxygen isotope composition of the laminated ores and dolomitic host rocks, Large et al. (2001a) estimated that the likely temperature of the brine pool in the HYC sub-basin was only $40^{\circ}$ to $70^{\circ} \mathrm{C}$. This compares with temperatures of $50^{\circ}$ to $67^{\circ} \mathrm{C}$ in the lower stratified brine pool at Atlantis II Deep (Hartman et al., 1997).

Current genetic models: In the previous $30 \mathrm{yr}$, since the first published research appeared, there have been two competing models regarding ore genesis at McArthur River; a syndiagenetic replacement model and a synsedimentary exhalative model. These two models are briefly discussed below and outlined in Figure 10.

The syndiagenetic replacement model has been supported by Williams (1978a, b), Logan (1979), Eldridge et al. (1993), Hinman, (1996), Logan et al. (2001), and Chen et al. (2003). In the most recent version (outlined in Fig. 10a; Logan et al., 2001; Chen et al., 2003), mineralization is envisaged to take place within the organic-rich sediments at a depth of 10 to 20 $\mathrm{m}$ below the sea floor, by hot $\left(250^{\circ}-400^{\circ} \mathrm{C}\right)$ metalliferous brines, which migrate along more permeable layers in the

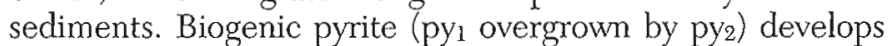
by diagenetic growth in the muds, followed by base metal sulfide precipitation resulting from reaction between organic material, sulfate, and base metal-bearing complexes in the hydrothermal fluid. Acid-generating, ore-forming reactions produced additional porosity through carbonate dissolution, which enables continuous lateral fluid migration. The evidence used to support this model includes microstylolitic textures in the laminated ore, which suggest carbonate dissolution is an important process, and the presence of organic biomarkers that are similar to those found in recent sub-surface hydrothermal systems, such as in the Guaymas basin (e.g., Simoneit, 1994). However, the model does not easily explain (1) the presence of laminated base metal sulfide clasts in the sedimentary breccias, (2) preferential concentration of the $\mathrm{Zn}$ and $\mathrm{Pb}$ sulfides in the fine-grained shale and siltstone beds rather than the coarser grained, more permeable, turbidite and mass-flow beds, (3) the close relationship between the ore lenses and interore sedimentary breccias (Ireland et al., 2004a), and (4) the circular zonation patterns of ore textures, nodular carbonates, and sulfur isotope values within and surrounding the deposit (Ireland et al., 2004b).

The syngenetic exhalative model at McArthur River, in which the sulfide minerals form above and within the upper layer of sea-floor muds, has been supported by Croxford and Jephcott (1972), Lambert (1976), Large et al. (1988, 2001a), and Ireland $(2004 \mathrm{a}, \mathrm{b})$. In the latest version (Large et al., 1998; Ireland et al., 2004b; Fig. 10b), the metalliferous ore fluid enters the brine pool, within the HYC sub-basin, in a series of pulses, each of which forms a bottom-hugging current. Fine-grained stratiform py precipitates due to bacterial sulfate reduction in the upper part of the brine pool. Each pulse of ore fluid mixes with brine along the brine-anoxic layer transition, leading to sphalerite-galena precipitation and coagulation to form sulfide aggregates, followed by gravitational collapse of the aggregates to the basin floor to develop the characteristic laminated base metal sulfide textures $\left(\mathrm{sp}_{\perp}\right)$. Subsequent $\mathrm{sp}_{2}$ forms by replacement of diagenetic carbonate nodules in the lower grade zones and margins of the lenses, followed by py, that grows in the sulfide muds by biogenic reduction (Ireland et al., 2004b). Metalliferous brine 


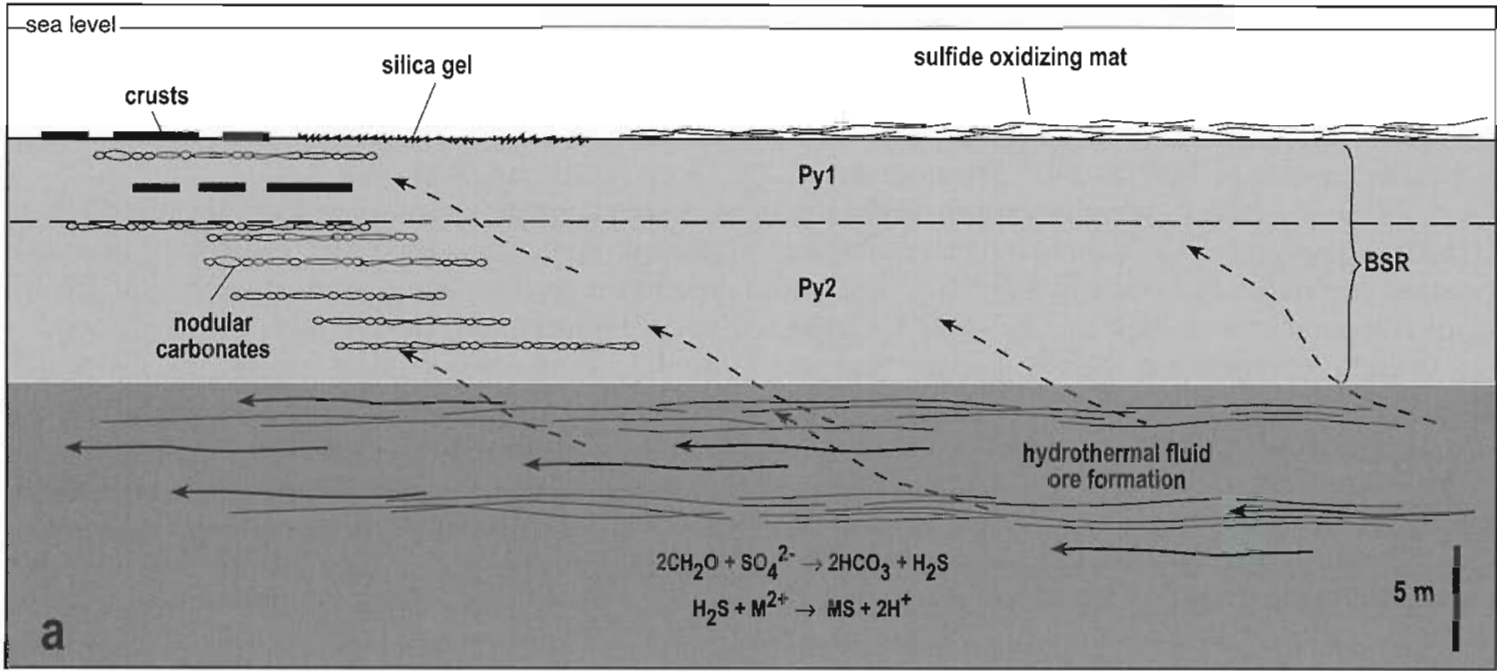

(1) Brine Influx and Pelagic Sedimentation

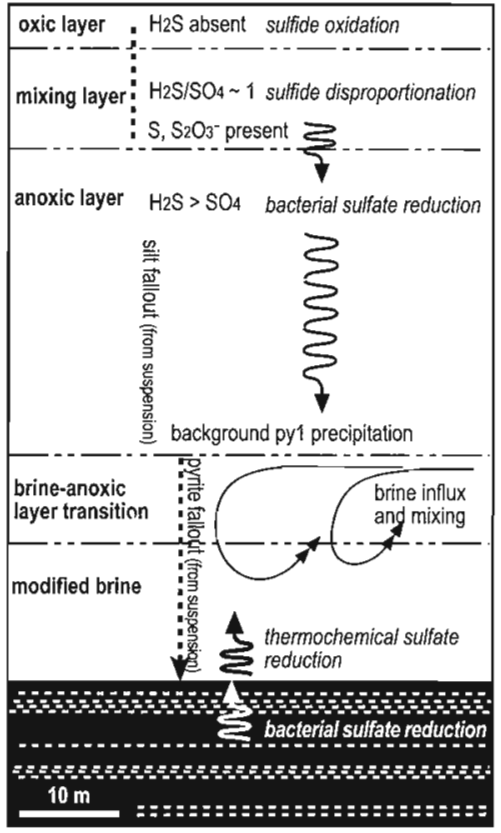

(2) Base metal Sulfide Precipitation

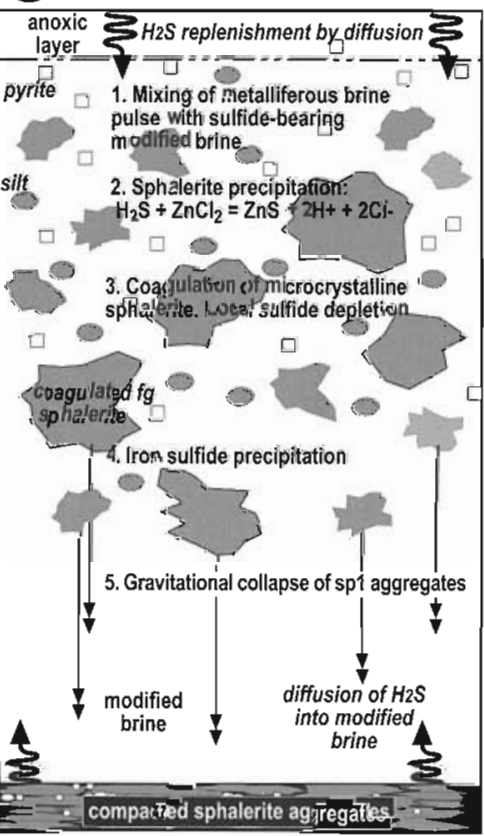

(3) In-situ Sulfide Precipitation

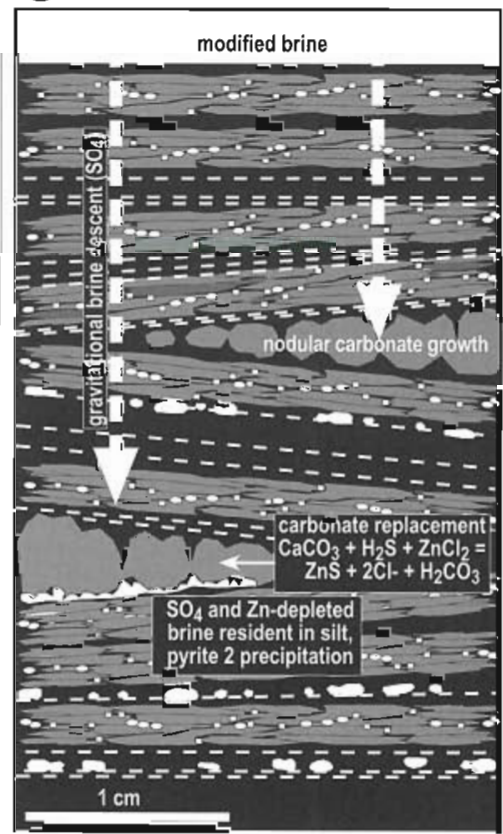

SsW

(1)

Atmosphere

NNE

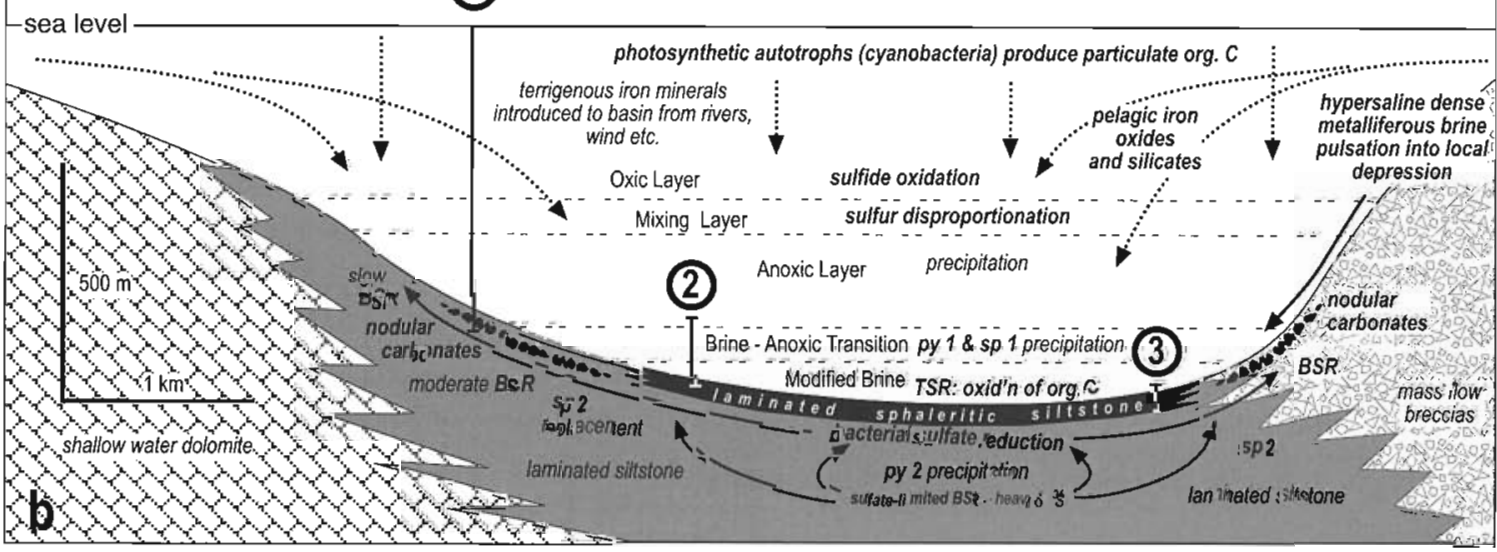


pulses, which precipitate sphalerite-galena, are interspersed with episodic siltstone turbidites, resulting in the finely laminated nature of the ore lenses. In support of this model, sulfide mineral paragenesis studies indicate the following order of deposition; py to sp to $\mathrm{sp}_{2}$ to $\mathrm{py}_{2}$. The first generation of sulfide minerals are layer-parallel and the second generation are nodular and replacive. A second line of supporting evidence is the observation that abundant laminated base metal sulfide clasts occur in the base of interore mass-flow breccias, indicating that laminated sulfides formed in the top meter of the sea floor before being ripped up and incorporated into the mass flows. In addition, mean sulfur isotope values of the different types of pyrite and sphalerite show a gradual increase with time that parallels the sulfide paragenetic sequence (Ireland et al., 2004b). Limitations of the exhalative syngenetic model are the lack of well-constrained data on the temperature and salinity of the ore fluids to support the establishment of a stratified brine pool from which metal sulfides precipitated, and the lack of any sulfide mounds or hydrothermal vent zones similar to those found in other sea-floor deposits.

\section{Century}

The stratiform zinc-rich Century deposit is located on the Lawn Hill platform, $250 \mathrm{~km}$ north-northwest of Mt. Isa (Fig. 1). The deposit is hosted by rocks of the Lawn Hill Formation, equivalent to the Wide sequence of Krassay et al. (2000), dated at $1595 \mathrm{Ma}$ (Page et al., 2000), which occurs at the stratigraphic top of the Isa superbasin. This formation is 40 to 50 m.y. younger than the sedimentary rocks hosting the McArthur River and Mt. Isa deposits (Fig. 5). Century has a higher $\mathrm{Zn} / \mathrm{Pb}$ ratio (6.8) than the other major Australian SEDEX deposits (1.2-2.9), with a geologic resource of 167.5 $\mathrm{Mt}(8.2$ wt $\% \mathrm{Zn}, 1.2 \% \mathrm{~Pb}$. and $33 \mathrm{~g} / \mathrm{t} \mathrm{Ag})$, including a higher grade mining resource of $1.55 \mathrm{Mt}(12.1$ wt $\% \mathrm{Zn}, 1.75 \% \mathrm{~Pb}$, and $46 \mathrm{~g} / \mathrm{t} \mathrm{Ag}$; Broadbent and Waltho, 1998). Although the deposit has many similarities to the synsedimentary McArthur River deposit, a very different, deep diagenetic replacement origin, synchronous with basin inversion, has been proposed (Broadbent et al., 1998, 2002).

Surface expression and discovery history: The Century deposit is located in low-lying, lightly timbered savannah plains, within peneplaned hills and ridges of moderate relief (approx $40 \mathrm{~m}$ ). Most of the deposit is covered by Cambrian limestones, eluvium, alluvium, flood-plain deposits, and black soil. Details of the discovery history are from Waltho and Andrews (1993), and Broadbent et al. (2002).
Although the first mining lease was granted in the area in 1887, covering the Silver King $\mathrm{Pb}-\mathrm{Zn}$ fissure vein deposit, active exploration during the 1950 to 1985 period by at least nine major mining companies, including the area of the present Century deposit, failed to locate a significant deposit. In the mid 1980s, CRA Exploration undertook an inhouse conceptual study on regional controls for base metal mineralization (Broadbent et al., 2002). The CRA Exploration model included concepts of hydrocarbon exploration and sought suitable structural closures in the Lawn Hill area. One such target emerged within the Lawn Hill circular structure, a Cambrian annulus that is $17 \mathrm{~km}$ in diameter (Fig. 11) and of impact or cryptoexplosive origin and which contained a central domal structure of prospective Lawn Hill Formation siltstones.

In January to April 1988, CRA established two $20-\mathrm{km}$ long regional magnetic and gravity traverse lines across the annulus, which were aligned northeast-southwest and northwest-southeast (Broadbent et al., 2002). At the southwestern end of the northeast-southwest traverse, a 1.6-km-long anomaly $(400->1,000$ ppm Zn) was detected in soils covering both Cambrian and Proterozoic rocks. In-fill soil sampling revealed a coherent $1.6 \times 0.6 \mathrm{~km}$ zinc anomaly $(1,000-3,000$ $\mathrm{ppm} \mathrm{Zn}$ ), with three samples also containing $>1,000 \mathrm{ppm} \mathrm{Pb}$ and as much as $8 \mathrm{ppm}$ Ag. The target was eventually drilled in April 1990, with hole LH4 intersecting $27 \mathrm{~m}$ at 6.3 wt percent $\mathrm{Zn}$. Century was discovered using soil geochemistry, with important lessons for explorers regarding lack of gossan development and geophysical expression of an orebody with low pyrite content and low iron in the sphalerite. It is significant that siting of the discovery drill hole was focused on a silver and lead soil anomaly within a more regional zinc anomaly. Such a pattern is also typical of the Mt. Isa, Hilton, and Lady Loretta group of deposits to the south.

Local geology and sedimentology: Similar to the other major northern Australian $\mathrm{Zn}-\mathrm{Pb}-\mathrm{Ag}$ deposits, Century is located adjacent to a regional synsedimentary fault, the Termite Range fault, considered to be the ore-fluid conduit (Fig. 11; Broadbent et al., 1998). However, unlike the McArthur River and Mt. Isa deposits, which are hosted in organic-rich, dolomitic, siltstone sequences, Century is hosted by siliceous, dolomite-poor black shale and siltstones. The host rocks are flat lying to gently dipping (Fig. 12), show broad-scale folding and faulting, and are unconformably overlain to the north by Cambrian limestone. The 300-m-thick mineralized sequence (termed the H4s unit; Andrews, 1998; Broadbent et al., 2002; Figs. 12 and 13 consists of interbedded siltstone, sideritic

FIG 10. Two competing ore genesis models for McArthur River deposit. a. Syndiagenetic replacement in muds below the sea floor (from Logan et al., 2001; Chen et al., 2003). Subsurface reaction between the metalliferous brine and sulfate with organic matter produces metal sulfides and bicarbonate. The bicarbonate precipitates as nodular carbonate in the overlying muds and downstream (Logan et al., 2001). b. Combination of syngenetic exhalative sulfide deposition ( $\mathrm{spl}_{1}$ and $\mathrm{pyl}_{1}$ ) with syndiagenetic replacement ( pyz and sp2) from Ireland et al. (2004b). bl = background rain of organic and inorganic pelagic sediment and ongoing water column precipitation of iron sulfides $\left(\mathrm{py}_{1}\right)$ occurs as iron in the modified brine and $\mathrm{H}_{2} \mathrm{~S}$ in the anoxic layer interact via diffusion, b2 = influx of a new pulse of metalliferous brine into the basin causes precipitation of sphalerite which flocculates to produce aggregates which are deposited as a sphalerite-rich layer $\left(\mathrm{sp}_{1}\right)$ on the sea floor, b3 $=$ nodular carbonates in the deposit fringes formed in the shallow subsea floor and are replaced by sphalerite ( $\mathrm{sp}_{2}$ ) as the modified brine permeated the sediment. Precipitation of nodular py, around nuclei of $p y_{1}$ occurs from the metal-depleted brine within the sediment (Ireland et al., 2004b). 


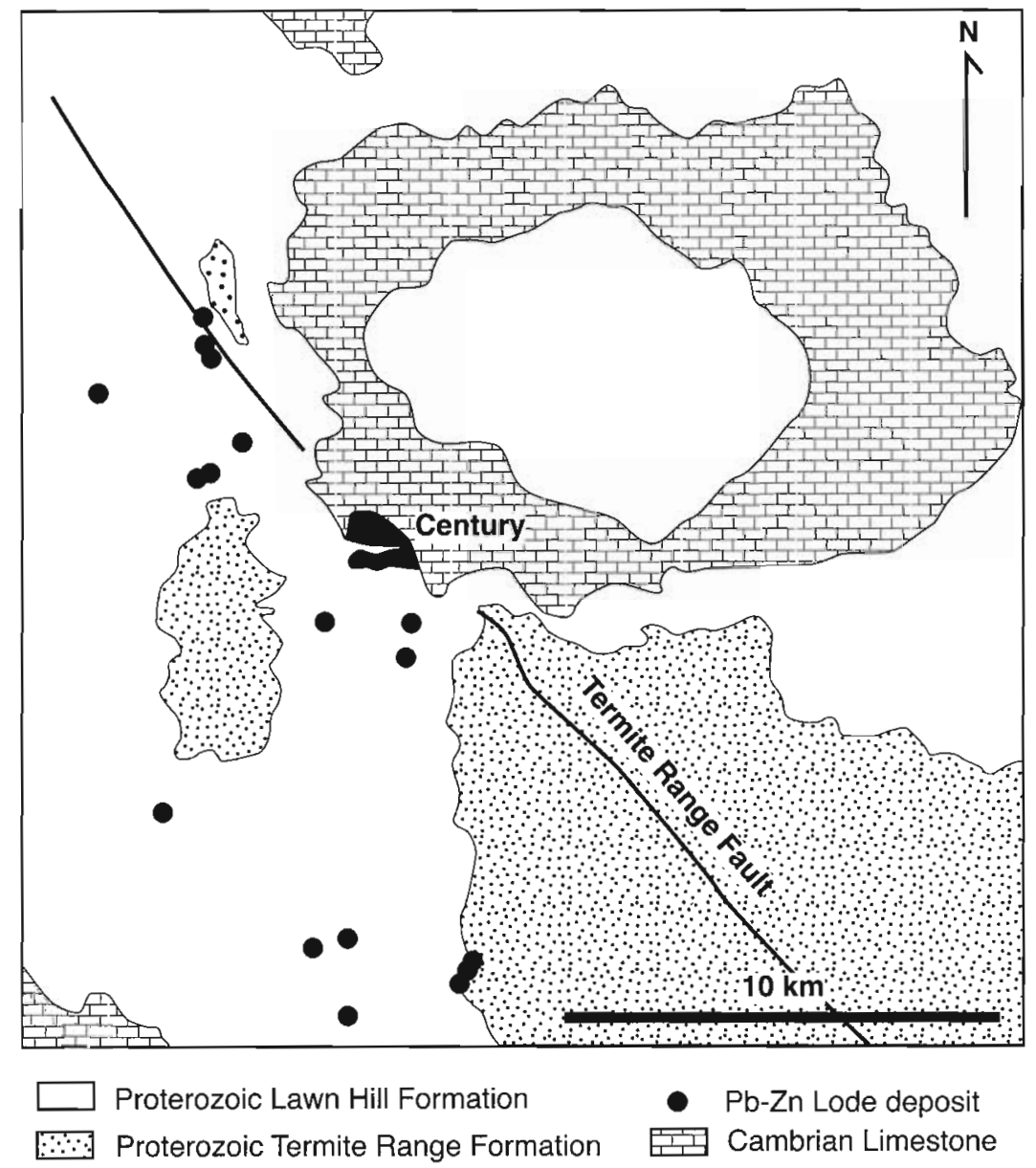

FIG. 11. Simplified regional geology of Lawn Hill mineral field, showing position of the stratiform Century Zn- $\mathrm{Pb}-\mathrm{Ag}$ deposit and the smaller crosscutting $\mathrm{Pb}-\mathrm{Zn}$ lodes in relationship to the Termite Range fault (modified from Broadbent et al., 1998).

siltstone, stylolitic siltstone, siliceous shale, and minor, quartzlithic, fine-grained sandstone. The $\mathrm{H} 4$ unit is one of six sedimentary units (denoted H1-H6; Andrews, 1998) that comprise the 1,800- to 2,200-m-thick sequence of shale, siltstone, sandstone, tuffaceous rocks, and minor dolomite comprising the Lawn Hill Formation (Broadbent et al., 2002). Sedimentological studies by Andrews (1998) suggested that the ore host rocks of the $\mathrm{H} 4 \mathrm{~s}$ unit were deposited in a deep-water, outer-shelf marine environment. High-grade $\mathrm{Zn}-\mathrm{Pb}-\mathrm{Ag}$ mineralization is confined to two major siliceous black shale subunits (subunits 2 and 4; Fig. 12), with thicknesses of approximately 5 and $10 \mathrm{~m}$, respectively. Thinner bands of mineralization (1-2 m) occur in shale and siltstone beds as far as $20 \mathrm{~m}$ above the upper ore lens (Fig. 12). There is a broad envelope of weak siderite development surrounding the deposit, extending for as much as $100 \mathrm{~m}$ into the hanging wall and $30 \mathrm{~m}$ into the footwall sediments (Fig. 13; Broadbent et al., 1998).

Mineralization textures and paragenesis: The ore lenses exhibit bedding-parallel laminated sphalerite-galena textures typical of most SEDEX deposits (Fig. 2b). However, unlike other deposits, pyrite is far less abundant, rarely exceeding 5 vol percent (Waltho and Andrews, 1993), and is concentrated in a halo immediately surrounding the deposit. Consistent with the low metamorphic grade, the sulfide minerals are very fine grained, with individual sphalerite grains having a diameter of about $0.3 \mu \mathrm{m}$, and sphalerite aggregates $\leq 30$ to 50 $\mu \mathrm{m}$ (Waltho and Andrews, 1993). Two stratiform types of sphalerite have been recognized; the more common porous sphalerite variety is preferentially developed in organic-rich microlaminae, and the nonporous type in siliceous microlaminae (Broadbent et al., 1998). Vein-style sphalerite and galena mineralization is also present and cuts the stratiform mineralization. Paragenetic studies by Broadbent et al. (1998) suggest that deposition of base metal sulfide minerals postdates formation of early diagenetic siderite and silica. They interpret the diagenetic paragenesis to be nodular silica cements to earliest siderite cements to stylolite development and sphalerite deposition. This paragenetic interpretation is critical to the argument for a subsea-floor diagenetic replacement origin for the deposit.

Metal relationships, metal zonation, and fluid flow: The lower mineralized zone is the most zinc rich, with generally low lead and silver grades (Fig. 12). There is a general decrease in $\mathrm{Zn} / \mathrm{Pb}$ ratio higher in the stratigraphy (e.g., hole LH52, Fig. 12), a similar trend to that repeated between 


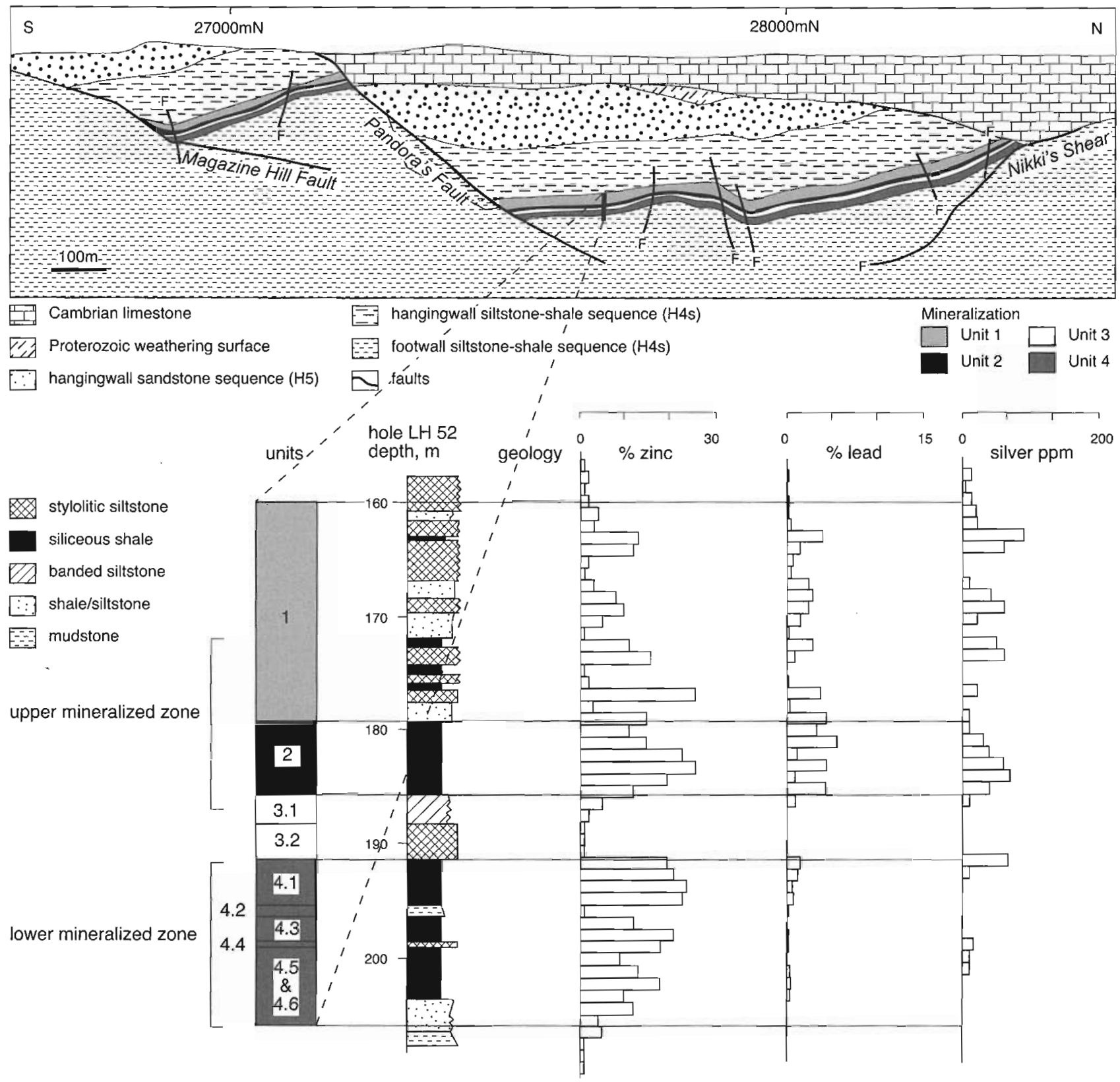

Fig. 12. Geology cross section and stratigraphic column of ore zones and downhole metal distribution at Century (compiled from Broadbent et al., 2002).

orebodies 2 to 4 and 5 to 8 at McArthur River (Fig. 7). Metal zonation studies by Waltho and Andrews (1993) and Broadbent et al. (1998) indicate a decrease in zinc and lead grades moving westward away from the Termite Range fault in the lower mineralized zone (subunit 4.3) and a similar,but less well-developed trend in the upper mineralized zone (subunit 2). A marked increase in lead content and decrease in $\mathrm{Zn} / \mathrm{Pb}$ ratio toward the southeastern corner of the deposit has been interpreted by Waltho and Andrews (1993) to suggest that the ore fluid entered the deposit area from the Termite Range fault, and migrated to the west and northwest, depositing sulfide minerals with an increasing $\mathrm{Zn} / \mathrm{Pb}$ ratio.
Relationship to organic matter: A striking feature of the Century deposit is the intimate relationship between hydrocarbons and mineralization. Pyrobitumen in various textural forms, including complex intergrowths with porous sphalerite, is concentrated in a 50- to 100-m-wide envelope surrounding the deposit (Broadbent et al., 1998). Textural evidence has been interpreted to indicate the main phase of pyrobitumen development predates base metal sulfide deposition. The relationship between pyrobitumen and sulfide minerals led Broadbent et al. (1998) to propose that the mineralized sequence at Century once hosted an accumulation of liquid hydrocarbons analogous to a source reservoir. This led 


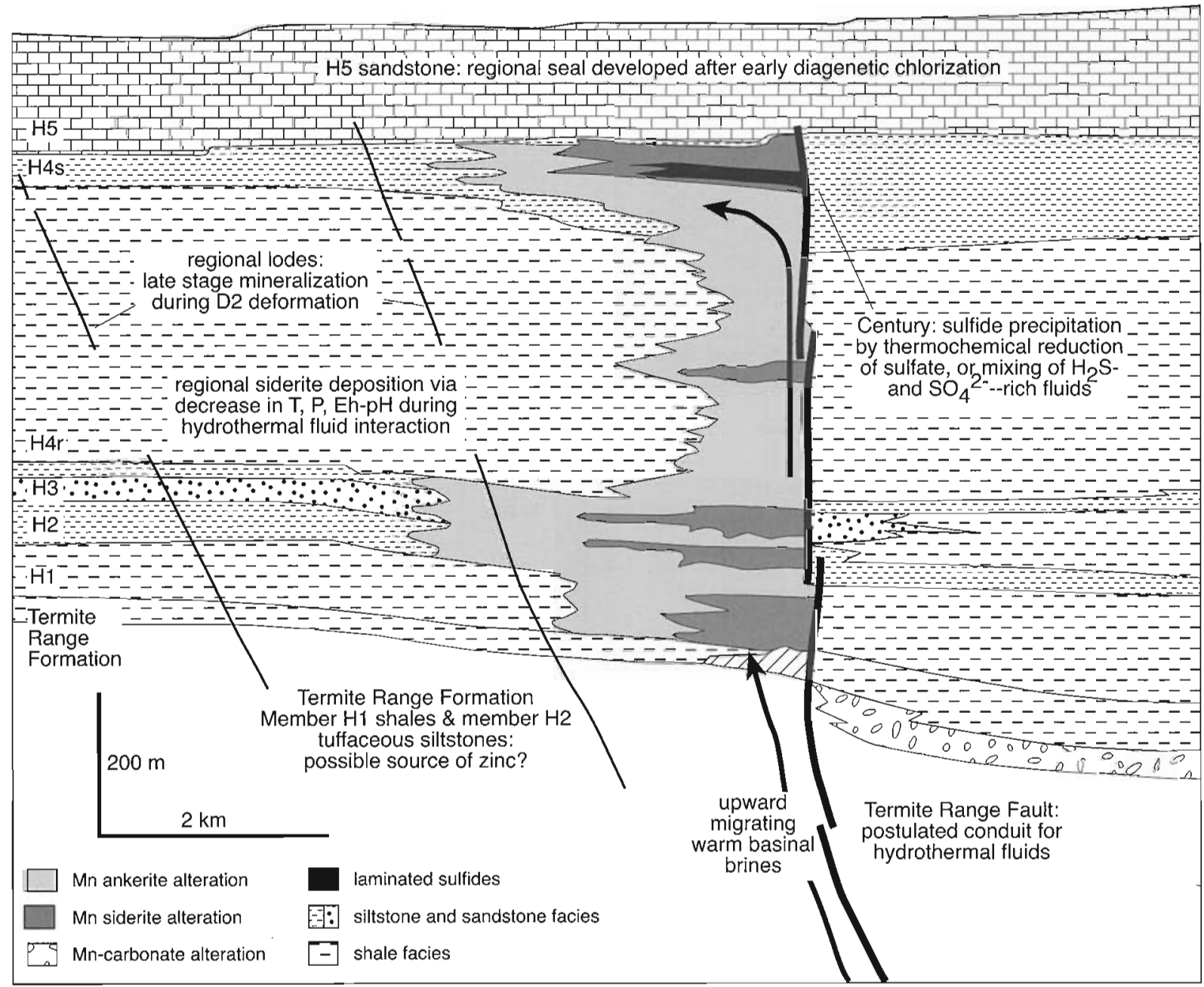

FIG. 13. Model for fluid flow, mineralization, and Fe-Mn carbonate alteration at Century (from Broadbent et al., 2002). The uppermost $\mathrm{H} 5$ sandstone was cemented during early burial by diagenetic chlorite and formed a barrier to subsequent upflow of metalliferous brines. The brines moved upward along the Termite Range fault and outward along favorable permeable horizons causing deposition of $\mathrm{Mn}$ siderite and $\mathrm{Mn}$ ankerite cements. The Century $\mathrm{Zn}-\mathrm{Pb}-\mathrm{Ag}$ lenses formed in the $\mathrm{H} 4 \mathrm{~s}$ siltstones below the impermeable cap of $\mathrm{H} 5$ chloritized sandstone due to reaction between hydrocarbons generated in the organic-rich $\mathrm{H} 4 \mathrm{~s}$ shales and sulfate and metal chlorides carried by the hydrothermal brines. The Mn siderite cements form a halo surrounding the deposit, being concentrated in areas of maximum temperature and fluid flow. Mn ankerite cements formed in the sediments more distal from the mineralization.

to the interpretation that the stratiform $\mathrm{Zn}-\mathrm{Pb}-\mathrm{Ag}$ ore lenses formed by selective replacement of more permeable horizons within the hydrocarbon trap site.

Carbonate alteration halo: Iron- and Mn-bearing carbonate minerals (ankerite and siderite) are concentrated in a halo immediately surrounding the deposit but also occur at lower abundances as carbonate cements in rocks over a large area of the Lawn Hill platform surrounding the Century deposit (Fig. 13; Andrews, 1998; Broadbent et al., 1998). In the mineralized sequence at Century, siderites contain an average of 7 to 20 wt percent $\mathrm{Mn}, 0.1$ to $5 \mathrm{wt}$ percent $\mathrm{Zn}$, and 3 to $18 \mathrm{wt}$ percent $\mathrm{Mg}$. The siderites show a gradual change in composition through the paragenesis; early-formed siderite is manganese and zinc rich, whereas later siderite, which is contemporaneous with zinc mineralization, is more magnesium and iron rich (Broadbent et al., 1998, 2002). Regionally, ankerite and manganese-rich siderite are disseminated within sedimentary rocks of units $\mathrm{H} 1, \mathrm{H} 2, \mathrm{H} 3, \mathrm{H} 4$, and $\mathrm{H} 6$ (Andrews, 1998). Manganese and zinc levels increase, and magnesium concentrations decrease, within siderite cements in the direction of the Century deposit (Broadbent et al., 1998). Andrews (1988) and Broadbent et al. (2002) considered that the distribution of $\mathrm{Fe}$ and $\mathrm{Mn}$ carbonate cements relates to hydrothermal fluid flow upward along the Termite Range fault and outward laterally along particular permeable sedimentary units (particularly $\mathrm{H} 1, \mathrm{H} 2, \mathrm{H} 3$, and $\mathrm{H} 4 \mathrm{~s}$ ), most probably preceding and during the Century $\mathrm{Zn}-\mathrm{Pb}-\mathrm{Ag}$ mineralization event (Fig. 13).

Sulfur isotopes: Base metal sulfides at Century vary from 6 to 18 per mil, with a mean value around 12 per mil, and about 5 per mil higher than the mean value for McArthur River (Fig A3). A trend of increasing mean $\delta^{34} \mathrm{~S}$ with each paragenetic 
stage in the Century region has been recognized by Broadbent et al. (1998). The laminated pyrite and sphalerite in the main orebody show a $\delta^{34} S$ range from 6 to 13 per mil, early and late veins vary from 9 to 18 per mil, and sulfides in the regional discordant lodes vary from 21 to 31 per mil. It is interesting that an increasing $\delta^{34} S$ trend with paragenetic stage is similarly recognized at the McArthur River deposit. Also, the main-stage stratiform sphalerite at the Century deposit has a similar isotopic range to the second-stage diagenetic replacement sphalerite $\left(\mathrm{sp}_{2}\right)$ at McArthur River (Ireland et al., 2004b). Broadbent et al. (1998) interpreted the isotopic progression at Century to indicate that the regional mineralizing fluid system was a closed reservoir, with progressive enrichment in heavy sulfur over the life of the mineralization and deformation events.

Carbon and oxygen isotopes: Carbonate cements and nodules within the mineralized sequence at Century exhibit considerable variation, with $\delta^{13} \mathrm{C}$ values from -2.6 to +2.6 per mil and $\delta^{18} \mathrm{O}$ values from 15.0 to 25.5 per mil (Fig. A5; Broadbent et al., 1998). This spread is similar to, but broader than, that exhibited by the regional marine sedimentary and diagenetic Proterozoic carbonates in the Mt. Isa-McArthur basin system (Fig. A5; Winefield, 1999; Lindsay and Brasier, 2000).

Lead isotopes: The majority of galena textural types at the Century deposit, including the fine-grained, laminated grains that are intergrown with sphalerite, have homogeneous lead isotope ratios, with a model age of $1575 \mathrm{Ma}$ (App. Fig. A6a). This is $\sim 20$ m.y. younger than the host rocks of the Lawn Hill Formation (1595 $\pm 6 \mathrm{Ma}$, Page and Sweet, 1998). This age difference supports the late diagenetic replacement origin for Century (e.g., Ord et al., 2002), based on the conclusions of Carr et al. (2001) that the lead isotope model accuracy is better than \pm 10 m.y. In close proximity to Century, the many small $\mathrm{Pb}-\mathrm{Zn}-\mathrm{Ag}$ veins of the Burketown mineral field (Lawn Hill lodes) display a wide range of isotopic ratios (Fig. A6b), with model ages between 1585 and $1485 \mathrm{Ma}$. Carr et al. (2001) interpreted these data as mixed leads from at least three events: (1) a very early event ( $1585 \mathrm{Ma})$, possibly synsedimentary in age; (2) a major epigenetic event $(\sim 1575 \mathrm{Ma})$ that was responsible for the deposition of the bulk of the Century sulfide mineralization; and (3) a later epigenetic event (1485 Ma) responsible for the Lawn Hill vein mineralization.

Fluid temperature estimates: Due to the fine-grained nature of the laminated ores at the Century deposit, no fluid inclusions of definite primary origin have been found and thus the temperature and salinity of the primary mineralizing fluid remains speculative. Pyrobitumen in the ores gives reflectance values of 2.1 to 2.7 percent Ro, suggesting maximum paleotemperatures between $180^{\circ}$ and $250^{\circ} \mathrm{C}$ (Broadbent et al., 1998). Polito et al. (in press) report fluid inclusion homogenization temperatures of $70^{\circ}$ to $125^{\circ} \mathrm{C}$, with salinities of 13 to 23 wt percent $\mathrm{NaCl}$ equiv, from coarse-grained sphalerite in the ore zone, but these may be related to metamorphism, rather than mineralization.

Current genetic model: The genetic model for Century proposed by Broadbent et al. $(1998,2002)$ involves late diagenetic replacement of a hydrocarbon reservoir within black shale facies, at a depth of $>1,000 \mathrm{~m}$, during the onset of basin inversion. In this model, sulfate-rich, metal-bearing brines move up the Termite Range fault and then spread laterally into black shale below an impermeable seal of chlorite-cemented sandstone (unit H5; Fig. 13). Sulfide minerals formed by replacement, along particular sedimentary laminae, where metal chloride complexes in the fluid reacted with $\mathrm{H}_{2} \mathrm{~S}$ generated by thermochemical reduction of sulfate related to thermal maturation of hydrocarbons in the black shale host sequence. Both oil- and gas-mediated precipitation were proposed by Broadbent et al. (1998). The model is similar to that proposed by Annels (1974) for stratiform copper mineralization in the Zambian copper belt. Critical evidence in support of this model at Century is (1) the intimate association of sphalerite and pyrobitumen in the ore zone, (2) the interpreted late-stage timing of the primary sphalerite, postdating formation of diagenetic silica and siderite, and (3) an apparent deposit-scale transgressive nature to the stratigraphic location of high-grade mineralization, although the laminated ores are bedding parallel. The lead isotope model age that is 20 m.y. younger than the age of the host sedimentary rocks is also supportive evidence; however, this interpretation may not be definitive due to the model age assumptions.

Despite the evidence presented in support of the deep syndiagentic replacement model, there are several problems that require further investigation (e.g., Broadbent et al., 2002). First, the apparent transgressive nature of the high-grade ore could be related to a change in fluid input or basinal depocenter. Second, the interpreted sulfide and silicate mineral paragenesis may relate to recrystallization of the ores during diagenesis and low-grade metamorphism and be unrelated to the order of primary mineral deposition (e.g., Feltrin et al., 2004). Third, the TSR, as proposed in the model, may not be a significant process at temperatures below $200^{\circ} \mathrm{C}$ (Ohmoto et al., 1990). Fourth, the high-grade mineralization is confined to the finest grained sedimentary units that were likely to have had the lowest permeability during deep diagenesis. By contrast, the sandstone units at Century, which would normally be considered more permeable, contain relatively little mineralization. In addition, the process of sulfate reduction and hydrocarbon oxidation associated with TSR is known to produce significant carbon isotope fractionation that would normally be recorded in the carbonate cements related to mineralization. Large negative shifts in $\delta^{13} \mathrm{C}$, from -15 to -40 per mil, are common in ore-related carbonates formed by oxidation of sedimentary organic carbon (e.g., Rollinson, 1993; Ohmoto and Goldhaber, 1997; Wilson et al., 2003; Selley et al., 2005). At Century, however, the $\delta^{13} \mathrm{C}$ values of -3 to +2 per mil recorded in ore-related carbonates (Fig. A5; Broadbent et al., 1998) are similar to values from typical regional sedimentary-diagenetic carbonates in the Mt. Isa-McArthur basin system (Veizer et al., 1992; Lindsay and Braisier, 2000) and are thus unlikely to be related to widespread oxidation of organic material.

In light of the uncertainties in the deep diagenetic replacement model, and because many of the features of Century are very similar to other SEDEX deposits (e.g., McArthur River), which formed by both synsedimentary and syndiagenetic processes within $10 \mathrm{~m}$ of the sea floor, a SEDEX genetic model for Century cannot be ruled out at this time.

\section{Mt. Isa, Hilton, and George Fisher (Mt. Isa district)}

These three major deposits, each containing $>100 \mathrm{Mt}$ of high-grade stratiform $\mathrm{Zn}-\mathrm{Pb}-\mathrm{Ag}$ ore, occur along a $25-\mathrm{km}$ 
strike length of the Urquhart Shale, immediately east of the Mt. Isa fault zone (Fig. 14). The total premining resource is $>370 \mathrm{Mt}$ (grading 10 wt \% $\mathrm{Zn}, 5.6 \% \mathrm{~Pb}$, and $120 \mathrm{~g} / \mathrm{t} \mathrm{Ag}$ ), which makes the overall $\mathrm{Mt}$. Isa mining district the world's premier $\mathrm{Zn}-\mathrm{Pb}$-Ag camp, comparable to the Red Dog mining district in Alaska (Leach et al., 2005). At Mt. Isa, a world-class copper resource ( $255 \mathrm{Mt}$ at $3.3 \mathrm{wt} \% \mathrm{Cu}$ ) occurs in the same stratigraphy adjacent to the $\mathrm{Zn}-\mathrm{Pb}-\mathrm{Ag}$ ore lenses. Compared to the McArthur River and Century deposits, the ores of the Mt. Isa district are significantly more deformed and highly metamorphosed. The metamorphic grade is middle greenschist facies, and as many as six deformation events have led to complex folding and faulting of the ores (e.g., Bell and Hickey, 1998). This has caused considerable sulfide and gangue mineral recrystallization and remobilization (Stanton, 1965; McClay, 1979) that have complicated genetic interpretations.

Surface expression and discovery history: In the Mt. Isa district, rocks of the pyritic Urquhart Shale formed prominent but discontinuous gossans and ironstone ridges rising to $40 \mathrm{~m}$ above the main river valley. This valley was constantly traversed by various travellers from 1910 to 1920 (Blainey, 1960), but it was not until February, 1923, when a young

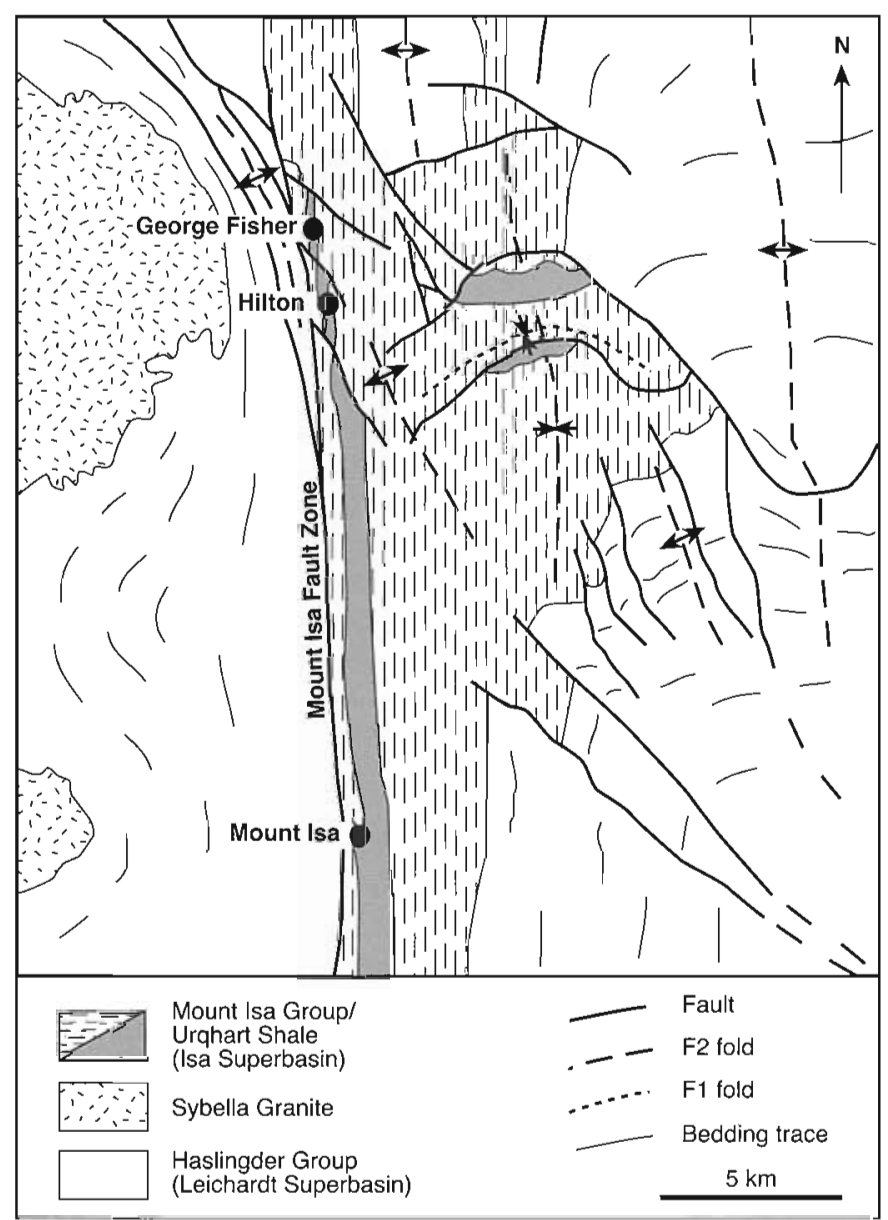

FIG. 14. Simplified regional geology of the Mt. Isa district, showing the location of the Mt. Isa, Hilton, and George Fisher $\mathrm{Zn}-\mathrm{Pb}-\mathrm{Ag}$ deposits, hosted in rocks of the Urquhart Shale adjacent to the Mt. Isa fault zone (modified from Chapman, 2004). prospector, Campbell Miles, sampled the low, red-brown, gossanous ridges across the valley to the west that the significance of the outcrops was recognized. His samples of black, yellow, and brown manganiferous and boxworked gossan contained abundant cerussite and assayed from 49.3 to $78.3 \mathrm{wt}$ percent $\mathrm{Pb}$ and 1 to $71 \mathrm{oz} / \mathrm{t} \mathrm{Ag}$, signalling the discovery of the world-class Mt. Isa Zn-Pb-Ag lodes (Blainey, 1960).

The Hilton and George Fisher deposits, located 18 to 20 $\mathrm{km}$ north of the Mt. Isa deposit (Fig. 14), occupy a separate, pyrite-rich, third-order basin also underlain by rocks of the Urquhart Shale. Although Hilton and George Fisher (formerly Hilton North) are separate deposits, they are arguably part of the same single pyritic sequence that is 3 to $4 \mathrm{~km}$ long and $300 \mathrm{~m}$ thick but separated by $600 \mathrm{~m}$ of left-lateral transcurrent fault movement (Fig. 14). The cerussite-bearing gossanous ridges at Hilton were discovered in 1947 and one year later the first diamond drilling intersected primary $\mathrm{Zn}-\mathrm{Pb}-\mathrm{Ag}$ sulfide mineralization similar to that at Mt. Isa (Forrestal, 1990).

The well-developed gossans at Mt. Isa, and to a lesser extent at Hilton, have provided important geochemical guidelines for the testing of gossans and ironstones at other, more recently explored localities in the Mt. Isa-McArthur basin system. Analyses from Taylor and Scott (1982) showed that gossan from the Black Star ore lenses at Mt. Isa contained as much as 9.4 wt percent $\mathrm{Pb}$, with also anomalous zinc and silver. In contrast, jaspery ironstone at 13 Mile Hill contains no more than $880 \mathrm{ppm} \mathrm{Pb}$ and $300 \mathrm{ppm} \mathrm{Zn}$, reflecting derivation of the siliceous ironstone from massive hanging-wall pyrite beds at the George Fisher deposit.

Local geology: The stratiform ore lenses occur within the upper $650 \mathrm{~m}$ of the $1,000-\mathrm{m}$-thick Urquhart Shale (dated at 1653 Ma, Page and Sweet, 1988; Fig. 6), which consists of a distinctive assemblage of mudstone, pyritic siltstone, and tuffaceous lithofacies (Chapman, 2004). Recent work suggests that the host sedimentary rocks were deposited in a deep-water submarine fan setting (Domagala et al., 2000), which contrasts with the previous interpretations of a shallowwater lacustrine basin setting (McClay and Carlisle, 1978; Neudert and Russell, 1981). Approximately 30 separate stratiform $\mathrm{Zn}-\mathrm{Pb}-\mathrm{Ag}$ lenses occur over about $650 \mathrm{~m}$ of stratigraphy at Mt. Isa (Fig. 15a). This compares with 7 to 10 ore lenses in $250 \mathrm{~m}$ of stratigraphy at Hilton (Fig. 15b) and 11 lenses in 350 $m$ of stratigraphic thickness at George Fisher (Forrestal, 1990; Chapman, 2004). Bedding-parallel, fine-grained pyrite is abundant throughout the host stratigraphy surrounding the three deposits. Painter et al. (1999) recorded pyrite abundances of 10 to $>50$ percent in selected bands of the siltstone rocks over a stratigraphic thickness of $800 \mathrm{~m}$ encompassing the $\mathrm{Zn}-\mathrm{Pb}-\mathrm{Ag}$ orebodies surrounding the deposits and extending for $>10 \mathrm{~km}$ north along strike. In comparison to the McArthur River and Century deposits, pyrrhotite is also a common sulfide phase at Mt. Isa, probably related to the higher degree of metamorphism and/or the subsequent introduction of the higher temperature copper mineralization.

Folding on scales of as much as $10-\mathrm{m}$ amplitude affected the ore lenses, with galena commonly coarsely recrystallized and concentrated into the fold hinges (Grondijs and Schouten, 1937; McClay, 1979; Forrestal, 1990). Mathias and Clark (1975) recorded an order of increasing sulfide mineral 


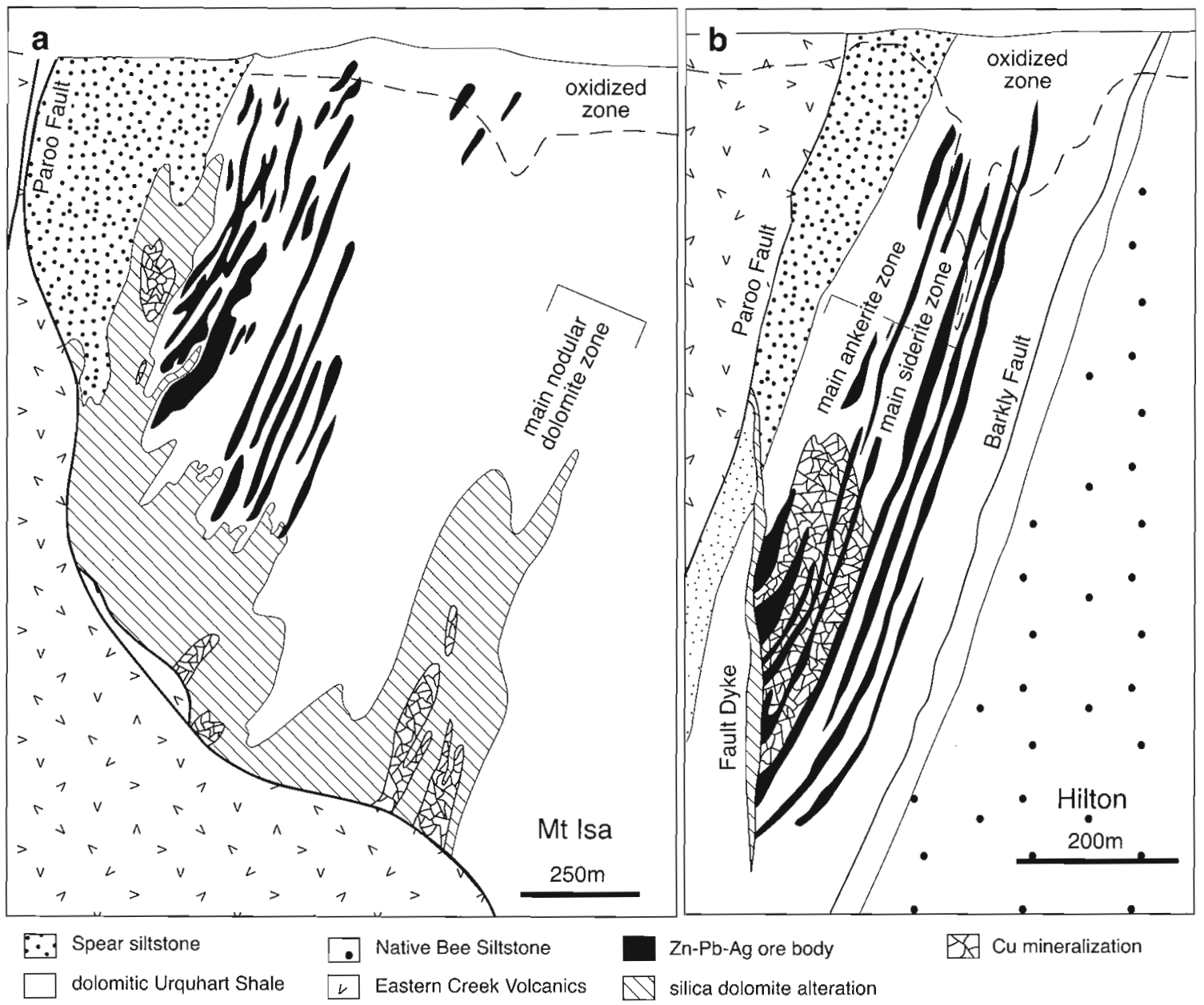

FIG. 15. Simplified geologic cross sections of Mt. Isa and Hilton (from Chapman, 1999). a. Northem cross section of Mt. Isa, showing the relationship between the separate stratiform $\mathrm{Zn}$-Pb-Ag lenses and the copper orebodies with surrounding, crosscutting, silica dolomite alteration. b. Simplified cross section of Hilton, showing the relationship between the stratiform $\mathrm{Zn}-\mathrm{Pb}-\mathrm{Ag}$ lenses and the low-grade zone of copper mineralization.

mobility, or remobilization, related to deformation: pyrite (least mobile), sphalerite, pyrrhotite, chalcopyrite, to galena (most mobile). Galena commonly occurs in late fractures, whereas sphalerite and pyxite are typically bedding parallel (Fig. 2c).

Metal zonation and relationship between $\mathrm{Cu}$ and $\mathrm{Zn}-\mathrm{Pb}-\mathrm{Ag}$ ores: There is a marked decrease northward in both copper content and $\mathrm{Pb} / \mathrm{Zn}$ ratio of ores, from the Mt. Isa to the George Fisher deposit. Mt. Isa contains a distinctly separate and high-grade copper zone (Fig. 15a), Hilton contains subeconomic copper grades at depth adjacent to the fault Dyke (Fig. 15b), and George Fisher contains only background amounts of copper (Chapman, 2004). The overall $\mathrm{Pb} / \mathrm{Zn}$ ratio of the stratiform lenses (Table 1) decreases from 0.86 (Mt. Isa) to 0.54 (Hilton) and to 0.47 (George Fisher). At Mt. Isa, the copper and $\mathrm{Zn}-\mathrm{Pb}$-Ag orebodies, although adjacent to one another (Fig. 15a), show distinctly different mineralogical, textural, and morphological attributes. The copper ores are encased in a complexly veined and brecciated zone of coarse quartz, carbonate, and sulfide minerals termed the "silica dolomite." The highest copper grades commonly occur in the most strongly silicified zones of the silica dolomite, which are adjacent to the basement Paroo fault and abutting the Eastern Creek volcanic rocks (Fig. 15a). The silica dolomite extends as a strata-bound zone of brecciation and replacement, mainly concordant with bedding in the black shales but becoming transgressive in the upper and northern sections (Fig. 15a; Mathias and Clark, 1975). Smith (2000) emphasized that the outer boundary of the silica dolomite reflects both the copper- and $\mathrm{Zn}-\mathrm{Pb}-\mathrm{Ag}$-rich hydrothermal events; the copper mineralization occurs within the silica dolomite in a regular fashion, whereas the $\mathrm{Zn}-\mathrm{Pb}-\mathrm{Ag}$ ore lenses interdigitate with and extend updip from the silica dolomite boundary (Fig. 15a). Within the individual base metal sulfide lenses, there is a regular zonation of pyrrhotite, galena, sphalerite, and pyrite away from the silica dolomite boundary (Mathias and Clark, 1975 , fig. 13). The $\mathrm{Pb} / \mathrm{Zn}$ ratio is at a maximum closest to the silica dolomite boundary, where $\mathrm{Pb} / \mathrm{Zn}>3$, and decreases along the ore lens away from the boundary to values of $\mathrm{Pb} / \mathrm{Zn}$ $<0.3$ (Davis, 2004). Although not as systematic as at the McArthur River and Century deposits, there is a general decrease in $\mathrm{Zn} / \mathrm{Pb}$ ratio of the ore lenses upstratigraphy at the 
George Fisher deposit. The lowermost lenses (H-E) have mean $\mathrm{Zn} / \mathrm{Pb}$ values of about 4 to 10 , whereas the upper lenses (D-A) have ratios of 1 to 4 (Chapman, 1999).

Mineralization textures and paragenesis: Except for the effects of sulfide mineral recrystallization and remobilization associated with metamorphism, the stratiform $\mathrm{Zn}-\mathrm{Pb}$-Ag ores in the Mt. Isa district exhibit similar laminated macrotextures to ores of the McArthur River and Century deposits (Fig. 2ac). On the microscale, Grondijs and Schouten (1937) interpreted the fine-grained pyrite atoll textures of sphalerite and galena replacing pyrite in the ores to indicate that the stratiform base metal ores formed by replacement of pyritic siltstones. However, Stanton (1964) pointed to the effects of metamorphism and annealing of the sulfide textures. He showed, by detailed grain boundary measurements and annealing experiments, that basically all sulfide mineral microtextures at Mt. Isa are related to the deformation of the ores, rather than revealing a classic sulfide paragenesis reflecting primary mineralization. In the following 30 years, the implications of Stanton's work have been commonly ignored and many researchers have attempted to interpret a primary sulfide paragenesis from the metamorphically modified textural relationships (e.g., Perkins and Bell, 1998).

In the less-deformed George Fisher deposit, Chapman (2004) has recognized four distinct textural styles within the ore lenses: (1) layer-parallel disseminated sphalerite within the carbonate-bearing siltstones, (2) layer-parallel, veinhosted sphalerite, (3) breccia-hosted sphalerite, and (4) veinand breccia-hosted galena. Chapman (2004) interprets the layer-parallel disseminated base metal sulfides to indicate subsurface replacement, possibly at shallow depth during diagenesis in semiconsolidated sediments, whereas the stratiform vein and breccia styles of mineralization are considered to relate to extensive textural modifications of the orebody during the subsequent metamorphic and deformation events.

Carbonate alteration halo: The $\mathrm{Zn}-\mathrm{Pb}-\mathrm{Ag}$ lenses in the $\mathrm{Mt}$. Isa district are surrounded by similar extensive manganeseand iron-bearing carbonate mineral and $\mathrm{Pb}, \mathrm{Zn}$, and $\mathrm{Tl}$ trace element halos to those observed at the McArthur River, Century, and Lady Loretta deposits (e.g., McGoldrick, 1986; Large and McGoldrick, 1998; Chapman, 1999; Large et al., 2000). However, the detailed nature of the carbonate alteration is affected by proximity to the copper orebodies and silica dolomite zones. At George Fisher, finely crystalline and zoned dolomite-ankerite-ferroan dolomite is the earliest recognized carbonate phase within and surrounding the deposit (Chapman, 1999). Similar zoned carbonates occur peripheral to the $\mathrm{Mt}$. Isa $\mathrm{Zn}-\mathrm{Pb}-\mathrm{Ag}$ lenses. In both cases, there is an increase in the iron and manganese content of the dolomite toward the ore lenses (Chapman, 1999). Fe-bearing carbonate alteration associated with the copper mineralization overprints the earliest carbonate assemblage related to $\mathrm{Zn}-\mathrm{Pb}-\mathrm{Ag}$ ores (Chapman, 1999).

Sulfur isotopes: The majority of $\delta^{34} S$ values of galena and sphalerite in the Mt. Isa deposit fall in the range from 10 to 20 per mil, whereas pyrite from the various $\mathrm{Zn}-\mathrm{Pb}-\mathrm{Ag}$ ore lenses has a wider range between -2 and +28 per mil (Fig. A4; Stanton and Rafter, 1966; Smith et al., 1978; Andrew et al., 1989, Painter et al., 1999). In a detailed study of the finegrained, bedding-parallel, synsedimentary pyrite to the north of Mt. Isa mine, Painter et al. (1999) measured values of 0 to 10 per mil for the majority of the grains. The difference between $\delta^{34} S$ values in the base metal sulfides and pyrite led Eldridge et al. (1993) to suggest that different sources of sulfur were involved. However, Painter et al. (1999) argued that the Mt. Isa data are compatible with a common sulfur source of ultimately marine sulfate origin for all sulfide mineral generations.

The $\delta^{34} S$ values of chalcopyrite, pyrrhotite, and coarsegrained pyrite in the crosscutting copper orebodies at the $\mathrm{Mt}$. Isa deposit have a similar range (10-20\%o) to that of the sphalerite and galena in the stratiform deposits (Fig. A4). Some workers have used this relationship to support a cogenetic origin related to a zoned $\mathrm{Cu}$ to distal $\mathrm{Pb}-\mathrm{Zn}$ ore system (e.g., McGoldrick and Keays, 1990; Painter et al., 1999).

Carbon and oxygen isotopes: Waring et al. (1998) emphasized the ${ }^{13} \mathrm{C}$-depleted isotope halo within and surrounding the silica dolomite zones and copper orebodies at the Mt. Isa deposit. They demonstrated that the isotopic values for carbonate minerals in the silica dolomite alteration $\left(\delta^{13} \mathrm{C}=-11\right.$ to $-3 \%$ and $\delta^{18} \mathrm{O}=10-14 \% 0$ ) contrasted strongly with those from nonmineralized dolomitic rocks of the Urquhart Shale $\left(\delta^{13} \mathrm{C}=-2\right.$ to $0 \%$ and $\delta^{18} \mathrm{O}=20-22 \%$ ), which are typical of Paleoproterozoic marine carbonates (Fig. A5). At the George Fisher deposit, where the later copper mineralization is absent, the iron- and manganese-bearing carbonates associated with the $\mathrm{Zn}-\mathrm{Pb}-\mathrm{Ag}$ lenses show intermediate isotopic values $\left(\delta^{13} \mathrm{C}=-4\right.$ to $-1.5 \% 0$ and $\left.\delta^{18} \mathrm{O}=17-18.5 \%\right)$ between the fields of least altered sedimentary carbonate and high-temperature hydrothermal carbonates related to copper mineralization (Chapman, 1999). These $\mathrm{Zn}-\mathrm{Pb}-\mathrm{Ag}$-related carbonates fall within the regional field for diagenetically altered carbonates (Fig. A5).

Lead isotopes: All three major $\mathrm{Zn}-\mathrm{Pb}-\mathrm{Ag}$ deposits, at Mount Isa, George Fisher, and Hilton, show very homogenous lead isotope values (Gulson, 1986; Carr et al., 2001), giving a model age of $1655 \mathrm{Ma}$ (Fig. A6a; Sun et al., 1994). This age is indistinguishable from the age of the Urquhart Shale host rocks (1652 $\pm 7 \mathrm{Ma}$, Page and Sweet, 1998) and supports a synsedimentary timing for the $\mathrm{Zn}-\mathrm{Pb}-\mathrm{Ag}$ ores. The copper ores from Mount Isa display lower ${ }^{207} \mathrm{~Pb} /{ }^{204} \mathrm{~Pb}$ ratios than the $\mathrm{Zn}-\mathrm{Pb}-\mathrm{Ag}$ ores and the HYC-Western fold belt growth curve (Fig. A6a; Carr et al., 2004), suggesting mixing of lead from the copper-bearing fluids with lead contributed from rocks of the Urquhart Shale. These isotopic data for the copper systems are too variable to provide model age information, but they are difficult to reconcile with formation of both the $\mathrm{Zn}$ $\mathrm{Pb}-\mathrm{Ag}$ and the $\mathrm{Cu}$ orebodies from the same fluid.

Fluid temperature estimates: The elevated metamorphic grade and intensity of deformation in the Mt. Isa district have precluded the use of fluid inclusions to determine temperatures related to formation of the $\mathrm{Zn}-\mathrm{Pb}-\mathrm{Ag}$ ore deposits. However, Painter et al. (1999) have argued that the sulfur isotope values of individual minerals remain unaffected by the metamorphism and suggest, based on deposit-scale equilibrium between sphalerite and galena, that the ores formed at $120^{\circ}$ to $240^{\circ} \mathrm{C}$. These temperatures are compatible with thermodynamic considerations of base metal transport and deposition in SEDEX systems (Cooke et al., 2000). Detailed studies of fluid inclusions from the silica dolomite zones at the Mt. 
Isa Copper deposit (Heinrich et al., 1989) suggest that the dolomite alteration occurred at $270^{\circ}$ to $350^{\circ} \mathrm{C}$ and 700 to 1,500 bars, followed by silicification and chalcopyrite deposition at $200^{\circ}$ to $350^{\circ} \mathrm{C}$ and 600 to 2,500 bars.

Current genetic models: The origin of the stratiform $\mathrm{Zn}-\mathrm{Pb}-$ $\mathrm{Ag}$ deposits in the Mt. Isa district has been hotly disputed over the past 50 years. The most contentious issue is the relationship between the timing and emplacement of copper and $\mathrm{Zn}-\mathrm{Pb}-\mathrm{Ag}$ ores. Three alternative models are discussed below.

Model 1. The $\mathrm{Zn}-\mathrm{Pb}-\mathrm{Ag}$ lenses formed during sedimentation, by shallow syndiagenetic replacement below the sea floor, whereas the copper ores formed much later during the Isan orogeny by syntectonic replacement (e.g., Gulson et al., 1983; Perkins, 1984; Heinrich et al., 1989; Chapman, 2004). Key evidence in support of this model is that the $\mathrm{Zn}-\mathrm{Pb}-\mathrm{Ag}$ lenses at the Mt. Isa deposit are analogous, in both composition and morphology, to the stratiform ores at McArthur River that are clearly of early syngenetic and/or syndiagenetic origin. In addition, lead isotope ages indicate that the lenses formed concurrent with sedimentation of the host Urquhart shales. In contrast, the copper ores are discordant and show replacement textures, and the associated silica dolomite alteration overprints the $\mathrm{Zn}-\mathrm{Pb}-\mathrm{Ag}$ mineralization.

Although this is currently the most widely accepted genetic model, its weakness is the proposed element of coincidence implied by such disparate timing of formation for two spatially overlapping world-class ore systems. When the copper and $\mathrm{Zn}-\mathrm{Pb}-\mathrm{Ag}$ orebodies are viewed on a single section ( Fig. 15a), the simple conclusion is that they are end members of a single, zoned, ore-forming system. This leads to the two other genetic possibilities.

Model 2. Both copper and $\mathrm{Zn}-\mathrm{Pb}$-Ag orebodies formed by syntectonic replacement during the Isan orogeny (e.g., Perkins, 1997; Perkins and Bell, 1998; Davis, 2004). Key evidence to support this model is the interpretation that the shape and location of both ore types are strongly influenced by faults and folds (Bell, 1983; Davis, 2004). Davis (2004) maintains that the $\mathrm{Zn}-\mathrm{Pb}-\mathrm{Ag}$ orebodies display the same structural controls as the syntectonic copper ores and appear to have been emplaced at the same time, during the last phase of the Isan orogeny.

There is, however, considerable evidence against this model. In particular; all the lead in the $\mathrm{Zn}-\mathrm{Pb}-\mathrm{Ag}$ ores is isotopically homogenous and has a model age indistinguishable from the age of tuffs in the host sequence. This strongly indicates that $\mathrm{Zn}-\mathrm{Pb}-\mathrm{Ag}$ mineralization was synchronous with sedimentation not much later, as required by the syntectonic model. Also, there has been total disregard in the structural studies used to support a late paragenesis for the base metal sulfides (Perkins, 1997; Davis, 2004) of the effects of metamorphism and deformation on recrystallization and annealing of the sulfide minerals (Stanton, 1964, 1965; McClay, 1979).

Model 3. Both the copper and $\mathrm{Zn}$-Pb-Ag ores formed early during sedimentation and diagenesis, in the upper tens of meters of sediment on and below the sea floor (e.g., Stanton, 1962; Finlow-Bates and Stumpfl, 1985; McGoldrick and Keays, 1990; Smith, 2000). In this model, the fault between the Eastern Creek volcanic rocks and rocks of the Urquhart Shale is interpreted as a synsedimentary feeder fault that controlled sub-basin development and hydrothermal fluid flow. The polymetallic ores were deposited either by exhalation on the sea floor or by syndiagenetic replacement below the sea floor in a similar manner to that interpreted in one of the above models for the McArthur River deposit. The silica dolomite zones and related copper ores formed a short time later, in a proximal position relative to the feeder fault, as the hydrothermal system intensified, became hotter, and was capable of transporting significant copper. It is possible that zonation of the base metal sulfide minerals and alteration gangue minerals was established during the copper overprinting, in a similar way to the process and effects of zone refining in sea-floor volcanogenic massive sulfide deposits (e.g., Huston and Large, 1989). At the George Fisher deposit, the lack of significant copper suggests that the hydrothermal system did not reach temperatures required to transport copper (probably at least $250^{\circ} \mathrm{C}$; Huston and Large, 1989).

Key evidence in support of the synsedimentary model is (1) the lead isotope age data of a synsedimentary timing for the $\mathrm{Zn}-\mathrm{Pb}-\mathrm{Ag}$ deposition, (2) metal and alteration zonation between the copper and $\mathrm{Zn}-\mathrm{Pb}-\mathrm{Ag}$ ores that suggests they are part of the one evolving hydrothermal system, (3) similarity in $\delta^{34} \mathrm{~S}$ values and S/Se ratios of the two ore types (McGoldrick and Keays, 1990), (4) similarities in the geometries of the $\mathrm{Zn}-\mathrm{Pb}-\mathrm{Ag}$ and copper orebodies that suggest they have the same structural history (Davis, 2004), and (5) $\delta^{34} \mathrm{~S}$ patterns that suggest an ultimate seawater origin for the sulfur in both ore types. Weaknesses, however, in the early cogenetic model are a lead isotope signature of the copper ores that is distinct from the $\mathrm{Zn}-\mathrm{Pb}-\mathrm{Ag}$ ores, suggesting either a different timing and/or different source areas for the fluids, and the two ore types typically show minimal spatial overlap, which is unlike many other zoned $\mathrm{Cu}-\mathrm{Zn}-\mathrm{Pb}$ syngenetic ore systems that exhibit significant overlap of the $\mathrm{Cu}$ and $\mathrm{Zn}-\mathrm{Pb}$ zones.

A major argument with model 3 has historically been the general acceptance of a syntectonic timing for deposition of the copper ores based on structural analysis (Perkins, 1984; Bell et al., 1988). However, in a recent review, Smith (2000) raised a number of significant concerns with that conclusion, maintaining that the association of copper ores with folding and deformation is incidental, not genetic, and no more pronounced than the relationship between structures and nonmineralized rocks of the Urquhart Shale. Also, he maintains strata-bound tongues of silica dolomite that extend away from the copper ores are folded together with the shales and $\mathrm{Zn}$ $\mathrm{Pb}-\mathrm{Ag}$ lenses, indicating that the silica dolomite formed predeformation. McGoldrick and Keays (1990) pointed out that the spatial distribution of $\mathrm{Bi}$-, Co-, and As-rich ore-related elements are intimately associated with the copper ores but are less effected by the deformation and are conspicuously strata bound, which suggests an original synsedimentary or syndiagenetic origin.

In summary, the current consensus among most workers supports the first model of synsedimentary $\mathrm{Zn}-\mathrm{Pb}-\mathrm{Ag}$ ores, which are overprinted by syntectonic copper mineralization. However, there are sufficient unanswered questions such that the cogenetic syngenetic and epigenetic models need further testing to evaluate their viability. 


\section{Cannington}

The Cannington deposit is located $200 \mathrm{~km}$ southeast of the Mt. Isa district and within the metamorphosed and deformed Eastern fold belt of the Mt. Isa Inlier (Fig. 1). The deposit exhibits significant differences compared to the above major stratiform $\mathrm{Zn}-\mathrm{Pb}-\mathrm{Ag}$ deposits in the Mt. Isa-McArthur basin system. These include a high-grade metamorphic host sequence of amphibolite-facies siliciclastic metasedimentary rocks, well-developed base and precious metal zonation, relatively high silver contents and high $\mathrm{Pb} / \mathrm{Zn}$ ratios in individual ore lenses, and a notable lack of pyrite. Geochemical associations are very similar to those of the giant Broken Hill deposit, and Cannington has been classified as a Broken Hilltype deposit (Walters and Bailey, 1996). Production of the deposit commenced in 1998, with an initial economic resource of $43.8 \mathrm{Mt}$ ( $11.65 \mathrm{wt} \% \mathrm{~Pb}, 4.4 \mathrm{wt} \% \mathrm{Zn}$, and $538 \mathrm{~g} / \mathrm{t}$ Ag; Walters et al., 2002), and the mine is currently the world's largest producer of silver and lead. Due to extensive and complex metamorphic and structural overprints, there has been considerable debate on genetic models. However, the bulk of the evidence supports a primary synsedimentary or syndiagenetic origin, with subsequent multiphase structural, metamorphic, and metasomatic overprinting resulting in significant sulfide mineral remobilization and localized upgrading of metal tenor (Bodon, 1998; Walters and Bailey, 1998).

Sunface expression and discovery history: Federal and state government mapping of the Mt. Isa Eastern fold belt in the early 1970s identified small lead- and zinc-rich prospects in rocks of the Soldiers Cap Group (e.g., Fairmile, Dingo, Pegmont) as showing similar geological features and geochemical associations to the Broken Hill deposit (Derrick, 1976; Blake, 1987). This was further highlighted by detailed studies of the Pegmont deposit (Stanton and Vaughan, 1979), emphasizing similarities to the complex Broken Hill-type iron formation lithologies that contained magnetite, garnet, and pyroxene.

In the early 1980s, BHP Minerals developed an integrated Broken Hill-type exploration model based mainly on the Broken Hill district and applied this model to an Australia-wide assessment (Walters et al., 2002). This identified the Soldiers Cap Group as a high priority unit and systematic exploration of areas underlain by these rocks commenced in 1984. The exploration program was characterized by the use of largescale regional airborne magnetic surveys for lithostratigraphic and structural mapping, as well as a potential direct targeting tool. Although the Broken Hill deposit is nonmagnetic, it was recognized that other Broken Hill-type deposits exhibited strong direct magnetic associations (e.g., Aggeneys-Gamsberg, South Africa) and magnetite associations occurred at several of the known prospects hosted by rocks of the Soldiers Cap Group. Use of large-area magnetic surveys highlighted the continuation of the prospective rocks of the Soldiers Cap Group under the extensive Cretaceous cover sequences on the eastern margin of the Mt. Isa Inlier and resolved several discrete high-amplitude magnetic responses of potential Broken Hill-type affinities in areas of shallow cover not previously explored (Skrzeczynski, 1998).

Initial testing of these targets intersected a large, but subeconomic Broken Hill-type system at the Altia prospect, which was associated with stacked, complex iron formations under
$30 \mathrm{~m}$ of Cretaceous cover (Walters et al., 2002). Regional evaluation of the Altia magnetic trend using a ground electromagnetic (EM) survey subsequently led to the discovery of the small, but high-grade Eloise $\mathrm{Cu}$-Au deposit in 1988 under $60 \mathrm{~m}$ of conductive Cretaceous overburden (Brescianini et al., 1992). This success led to the progressive extension of the regional airborne magnetic coverage and a focus on the adjacent, poorly explored area under cover. An extensive magnetic survey was flown in July 1989, extending south of the Eloise deposit, with 23 targets selected for drill testing (Whiting, 1996). The third target was drilled on an intense magnetic bulls-eye in July 1990 and intersected $20 \mathrm{~m}$ of $12.1 \mathrm{wt}$ percent $\mathrm{Pb}, 0.6$ wt percent $\mathrm{Zn}$, and $870 \mathrm{ppm} \mathrm{Ag}$ under $40 \mathrm{~m}$ of cover (Walters et al., 2002). Subsequent evaluation indicated that the discovery intersection represented the narrow updip extension of the main economic resource, which occurs mainly between 300 to $600 \mathrm{~m}$ below surface. The carbonaceous and pyritic nature of the Cretaceous cover sequences creates significant difficulties in the routine application of electrical geophysical and surface geochemical techniques, particularly in areas with $>100 \mathrm{~m}$ of cover.

Deposit geology: The principal host rock at Cannington is a monotonous sequence of compositionally banded quartzofeldspathic migmatitic gneiss, interpreted to represent metamorphosed immature siliciclastic sediments deposited during the early stages of intracontinental rifting (Mark et al., 1998; Bodon, 2002). The biotite-sillimanite-garnet gneisses are intercalated with subordinate amphibolites and pegmatites, thin quartzites, and rare $\mathrm{Fe}$ - and $\mathrm{Mn}$-rich silicate units. Regional metamorphic grade is upper amphibolite facies, with no unequivocal primary sedimentary textures. Dating of detrital zircons in interpreted lithostratigraphic equivalents cropping out $30 \mathrm{~km}$ north of Cannington indicates a maximum depositional age of $1677 \pm 9 \mathrm{Ma}$ (Page and Sun, 1998), with peak metamorphism dated at 1600 to $1580 \mathrm{Ma}$, based on zircon overgrowths at Cannington (Giles and Nutman, 2003).

Mineralization is broadly stratiform, with a series of tabular stacked lenses repeated around a tight to isoclinal recumbent synform that controls the overall deposit geometry (App. Fig. A7). Late movement on the northwest-trending Trepell fault cuts the orebody into northern and southern zones with a relative displacement of about $100 \mathrm{~m}$ (Walters et al., 2002, fig. 11). The mineralogy and composition of the strata-bound Ag$\mathrm{Pb}-\mathrm{Zn}$ ore lenses is complex compared to the stratiform $\mathrm{Zn}$ $\mathrm{Pb}-\mathrm{Ag}$ deposits in the Mt. Isa-McArthur basin system but show remarkable similarities with the Broken Hill deposit.

Eight mineralization types have been grouped into four main ore lenses that are repeated in the structural hanging wall and footwall of a major recumbent synform (Fig. A7; Walters and Bailey, 1998). The main ore types are (1) leadand silver-dominant, iron-rich, (2) siliceous $\mathrm{Zn}-\mathrm{Pb}$, (3) siliceous zinc-dominant, and (4) iron-rich, low-grade zinc. The high-grade $\mathrm{Fe}$-, $\mathrm{Pb}$-, and $\mathrm{Ag}$-rich ore lenses are characterized by a gangue assemblage of fluorite-hedenbergitepyroxmangite-quartz-magnetite-fayalite-pyrrhotite and are manganese enriched, whereas the siliceous zinc- and leadrich lenses have a quartz-carbonate-arsenopyrite gangue assemblage with lower concentrations of manganese (Walters et al., 2002). Dominant sulfide minerals are galena, sphalerite, and pyrrhotite, with minor arsenopyrite, loellingite, and 
chalcopyrite, and traces of pyrite. The high silver grades that characterize the deposit are related to argentiferous galena with abundant inclusions of friebergite (Walters and Bailey, 1998). It is notable that about one-half of the economic mineralization displays a strong magnetite-pyrrhotite association, whereas the remainder is associated with nonmagnetic assemblages.

Metal zonation: Cannington ore lenses show extreme $\mathrm{Pb} / \mathrm{Zn}$ zonation trends with rapid variations in grade and thickness. The $\mathrm{Pb} / \mathrm{Zn}$ ratios are on the order of 6 to 10 , with marked contrast over tens of centimeters between zinc- versus leaddominant ore lenses. The predominance of lead- and silverrich, high-grade ore lenses is one of the characteristic economic features of the Cannington deposit that contrasts with the stratiform $\mathrm{Zn}-\mathrm{Pb}-\mathrm{Ag}$ deposits in the $\mathrm{Mt}$. Isa-McArthur basin system and is unusual even in comparison with the Broken Hill deposit. The anomaly has been explained in terms of postpeak metamorphic metasomatism involving high-salinity fluids, which led to extreme zone refining with preferential lead and zinc redistribution (Walters and Bailey, 1998).

The lead- and silver-dominant ore lenses occur on the outside of the synformal fold repetition. Along the limbs, the ore lenses are generally iron rich, relatively thin, and show a variety of boudinage and ductile breccia textures. Thickening occurs in parasitic folds with the highest grade mineralization in the hinge of the major synform. Metal concentration in the hinge region is characterized by coarse-grained galena and sphalerite and a gangue of quartz carbonate. This ore appears to represent the product of postpeak metamorphic metasomatism that overprints the iron-rich mineralization types. Typical high-grade intersections include $55 \mathrm{~m}$ at 26.6 wt percent $\mathrm{Pb}, 10.4$ wt percent $\mathrm{Zn}$, and $1321 \mathrm{ppm} \mathrm{Ag}$ (Walters and Bailey, 1998).

Ore lenses in the central zone of the synform, updip from the hinge zone (Fig. A7), are zinc dominant, with marked contrasts between siliceous and iron-rich gangue assemblages. Iron-rich lenses are characterized by abundant pyrrhotitemagnetite, with minor chalcopyrite, arsenopyrite, and loellingite. Although mainly subeconomic, these lenses are associated with a distinctive $\mathrm{Zn}-\mathrm{As}-\mathrm{Cu}-\mathrm{Bi}-\mathrm{Au}$ geochemical signature, with grades on the order $-0.5 \mathrm{wt}$ percent $\mathrm{Cu}$ and 0.2 to $0.3 \mathrm{ppm} \mathrm{Au}$, and with $1-\mathrm{m}$ intersections of as much as 6.5 wt percent As and 2.6 percent $\mathrm{Cu}$ (Walters and Bailey, 1998).

Mineralization textures and paragenesis: The ore lenses show variable effects of intense metamorphism, recrystallization, remobilization, and metasomatic overprinting (Bodon, 1998; Walters and Bailey, 1998). Bodon (2002) summarized the main textural types as (1) crudely banded, coarse-grained sulfide minerals on a centimeter scale, (2) granoblastic sulfide-silicate intergrowths with spheroidal sulfide inclusions in silicate minerals, (3) durchbewgt textures (silicate nodules in a recrystallized massive sulfide matrix) indicative of intense deformation in massive sulfides, (4) anastomosing mylonitic zones in fluorite- and magnetite-rich ores, and (5) quartz sulfide breccias. Fracturing and brecciation of siliceous ore lenses are characteristic features, with boudinage and ductile milling textures in more sulfide-dominant and fluorite-rich assemblages.

Bodon (1998) interpreted the presence of base metal sulfide inclusions in peak metamorphic mineral phases as evidence that mineralization predates deformation and metamorphism. However, the majority of textural and spatial relationships reflect complex peak and postpeak metamorphic anhydrous and hydrous paragenetic events (Williams et al., 1996; Chapman and Williams, 1998). Annealed magnetite-pyroxenoid-olivine-( $( \pm$ sulfide-fluorite) assemblages are interpreted to have formed during metamorphism, with extensive overprinting zones of postpeak metamorphic anhydrous metasomatism consisting of hedenbergite-gamet-quartz- $( \pm$ fluoritesulfide) alteration typically associated with ductile milled breccias. These are, in turn, overprinted by more restricted zones of lower temperature pyrosmalite-ilvaite-chloritegreenalite-homblende-( \pm sulfide-fluorite)-dominant hydrous metasomatism.

Alteration halo: A roughly strata-bound alteration halo is defined by the presence of fine-grained, disseminated, pink garnet within the quartzo-feldspathic gneissic host rocks. The halo extends as far as $250 \mathrm{~m}$ into the hanging wall of the southern zone (Fig. A7; Walters et al., 2002). The alteration zone is characterized by anomalously high $\mathrm{K} / \mathrm{Na}-\mathrm{Ca}$ ratios, which can be related to the destruction of albite, development of $\mathrm{K}$-feldspar and muscovite, and elevated whole-rock lead (100-300 ppm) hosted by Pb-bearing K-feldspar (Stanley et al., 2001). Proximal to ore, intensely altered metasedimentary rocks are enriched in $\mathrm{Fe}, \mathrm{Mn}$, and $\mathrm{Si}$, with the development of "garnet sandstones," blue quartz, and gahnite (Walters et al., 2002). The alteration halo contains rare sulfide minerals, no magnetite, and is not associated with veining or brecciation.

Sulfur isotopes: Unlike the other stratiform $\mathrm{Zn}-\mathrm{Pb}-\mathrm{Ag}$ deposits, which show a wide spread in sulfide $\delta^{34} \mathrm{~S}$ values, the strata-bound Cannington Ag-Pb-Zn deposit exhibits a very tight distribution, with the majority of values from 4 to 8 per mil (Fig. A4). The narrow range is similar to that for sulfide minerals at Broken Hill (Gustafson and Williams, 1981), suggesting that metals and $\mathrm{H}_{2} \mathrm{~S}$ were probably carried together in the ore fluid, and that sulfate reduction, whether biogeneic or thermochemical, was probably not an important process for sulfide deposition. The narrow $\delta^{34} \mathrm{~S}$ distribution and the lack of barite in the ore suggest that the deposit did not form in a low-temperature oxidized sea-floor environment.

Lead isotopes: Lead isotope data for sulfide minerals from deposits in the Mt. Isa Eastern fold belt, including Cannington, Dugald River, Pegmont, and Monakoff, lie on a different growth curve, with lower ${ }^{207} \mathrm{~Pb} /{ }^{204} \mathrm{~Pb}$ ratios, than for sulfides from $\mathrm{Zn}-\mathrm{Pb}-\mathrm{Ag}$ ores in the remainder of the Mt. IsaMcArthur basin system (Fig. A6a, Carr et al., 2001). The Eastern fold belt curve (Fig. A6a) is based on the same assumptions as the McArthur-Mt. Isa Western fold belt curve but was calculated using different $\mathrm{U} / \mathrm{Pb}$ and $\mathrm{Th} / \mathrm{Pb}$ values (App. Table Al). The main stratiform Ag-Pb-Zn lenses at the Cannington deposit are characterized by a very homogenous lead isotope signature (Fig. A6a). The model age of $1665 \mathrm{Ma}$ is close to the age of the host sequence $(1677 \pm 9 \mathrm{Ma})$ and significantly older than the $\sim 1600$ to $1500 \mathrm{Ma}$ Mt. Isa orogen, consistent with a synsedimentary or syndiagenetic origin for the deposit (Bodon, 2002). The low ${ }^{207} \mathrm{~Pb} / 204 \mathrm{~Pb}$ ratio of the Cannington ores, compared with other northern Australian SEDEX ores (Fig. A6a), indicates that the lead came from a more primitive, mantle-derived source. A second population 
of lead isotope data is evident in association with minor late galena veins at Cannington (Bodon, 2002), which exhibits a broader range of ${ }^{206} \mathrm{~Pb} /{ }^{204} \mathrm{~Pb}$ ratios that also plot on the Eastern fold belt curve. This second population is interpreted to represent mixing of lead from high lead (very low $\mu$ ) reservoirs (e.g., existing Cannington age strata-bound $\mathrm{Ag}-\mathrm{Pb}-\mathrm{Zn}$ mineralization) with lead from the regional source rocks during an event at least $80 \mathrm{~m} . \mathrm{y}$. younger, which probably is associated with amphibolite facies metamorphism during the Isan orogeny (Bodon, 2002).

Comparison between Cannington and other stratiform deposits: The major differences between Cannington and the $\mathrm{Zn}-\mathrm{Pb}-\mathrm{Ag}$ stratiform deposits in the Mt. Isa-McArthur basin system are listed in Table 2 . These suggest a different genetic model and a different approach to exploration for SEDEX and Broken Hill-type ores (e.g., Leach et al., 2005).

Current genetic models: Due to the protracted period of metamorphism and deformation in the area of the Cannington deposit, there has been considerable debate about its origin. Two genetic models have been developed.

1. Distal skarn model: Some workers have argued that the deposit formed postpeak regional metamorphism, when highsalinity, high-temperature, metalliferous magmatic fluids interacted with a preexisting calcareous horizon (Williams et al., 1996; Chapman and Williams, 1998). Evidence to support the model includes: (1) the manganese-rich, skam-like assemblages that are similar to those in zinc skarns elsewhere (e.g., Meinert et al., 2005), (2) the late-stage, crosscutting, and retrogressive nature of much of the mineralization, and (3) the presence of paragenetically late, high-salinity, metal-bearing fluid inclusions. The critical evidence against the skarn model is the lead isotope data, which show that the primary galena introduction was roughly synchronous with sedimentation or diagenesis at $\sim 1675 \mathrm{Ma}$, and that little or no lead was added to the deposit during or after peak metamorphism and metasomatism (75-150 m.y. later). Also, no granites of Isan orogeny age, which are required to be the source of the fluids, are known in the region.

2. Modified synsedimentary model: The alternative model suggests that the deposit formed on or below the sea floor, during sedimentation, from deeply sourced sedimentary brines. Metals were remobilized and zone refined during subsequent metamorphic and metasomatic events but without significant external metal addition (Bodon, 1998, 2002; Walters and Bailey, 1998). Critical evidence to support the model includes: ( 1 ) the strata-bound nature of the ores and the manner in which they have been folded and recrystallized, which is compatible with a premetamorphic deformation, (2) lead isotope data that indicate a synsedimentary age, although with a mantle or deep-crustal lead source, and (3) fine-scale, laterally continuous and compositionally diverse banding in some of the peripheral ore types that are similar to exhalative chemical sediments with a variable detrital component (Bodon, 2002). Features of Cannington which are not easily explained by the synsedimentary model are the lack of barite, even though the ore assemblage suggests an oxidized sedimentary environment, and the extreme $\mathrm{Mn}$ enrichment in some ore lenses, which is an order of magnitude greater than commonly found in sea-floor $\mathrm{Zn}-\mathrm{Pb}$-Ag deposits.
Large et al. (1996) have argued that one of the significant differences between Broken Hill-type deposits, such as Cannington, and the general class of SEDEX Zn-Pb-Ag deposits, relates to the relative redox difference between the ore-fluid and the sedimentary environment. The northern Australian SEDEX deposits are considered to result from oxidized, sulfate-bearing, metalliferous brines being exhaled or infiltrated into a reduced anoxic sedimentary basin (Cooke et al., 2000). Metal deposition is related to fluid mixing followed by BSR or TSR, which produces the $\mathrm{H}_{2} \mathrm{~S}$ required for reaction with metal complexes. In contrast, Broken Hill-type deposits probably form from reduced, acidic, $\mathrm{H}_{2} \mathrm{~S}$-bearing, metalliferous brines, which are exhaled or infiltrated into an oxic sedimentary basin. In this case, metal deposition is promoted by mixing and cooling, $\mathrm{fO}_{2}$ increase, or $\mathrm{pH}$ increase.

\section{Basin-Scale Fluid Flow Models}

There is general consensus that stratiform, sedimentary rock-hosted $\mathrm{Zn}-\mathrm{Pb}$-Ag deposits result from regional-scale, intrabasinal fluid flow involving metal leaching from particular volcanic and/or sedimentary lithologies of the basin. However, there are a number of potential driving mechanisms for regional fluid flow in sedimentary basins, including sediment compaction, free convection due to density variations, meteoric-water recharge associated with development of topography, and pressure gradients associated with the onset of deformation. Recent hydrological modeling of the northern Australian Proterozoic basins has focused on free convection in the case of the McArthur River deposit (Garven et al., 2001; Yang et al., 2004b) and topographic and deformation driven flow in the case of the Century deposit (Ord et al., 2002). These models have provided new insights into the potential controls on regional fluid flow and mineralization.

\section{Free convection models}

Garven et al. (2001) used numerical hydrological modeling to examine the role of basin-scale fluid migration in the formation of the McArthur River deposit. In this study, a finite element mesh was constructed from a simplified geologic cross section, through the southern McArthur basin, in the area of the orebody (Fig. 16a). To construct the model, the stratigraphy was simplified to five hydrostratigraphic elements (Fig. 16a); deep mafic and felsic volcanic rocks, clastic and minor volcanic rocks of the lower Tawallah Group ( Leichhardt and Calvert superbasin strata), and the platform carbonates of the McArthur Group were all assigned relatively low porosities and hydraulic conductivities. The clastic rockdominated succession of the upper Tawallah and lower McArthur Group, deposited at the base of the Isa superbasin and buried to depths of $<5 \mathrm{~km}$, was considered the main stratal aquifer:

The hydrologic model outlined above was used to investigate a number of different scenarios, including fluid flow driven by surface topography, sediment compaction, and release of pore-fluid overpressure due to fault rupture. However, Garven et al. (2001) concluded that the most likely hydrologic regime active during deposition of material within the lower half of the Isa superbasin was free convection, driven by density variations resulting from the normal geothermal gradient (Fig 16b, c). Convective circulation had originally been 
(a) Hydrostratigraphy

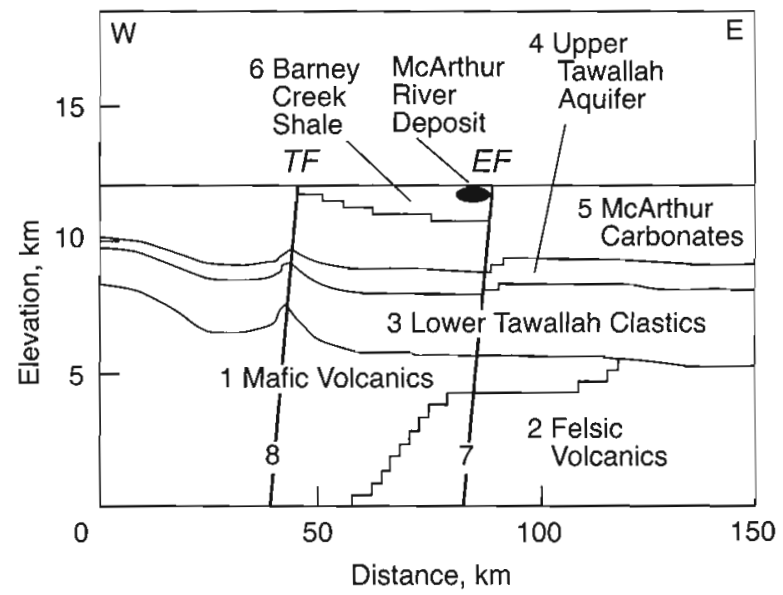

(b) Fluid flowlines

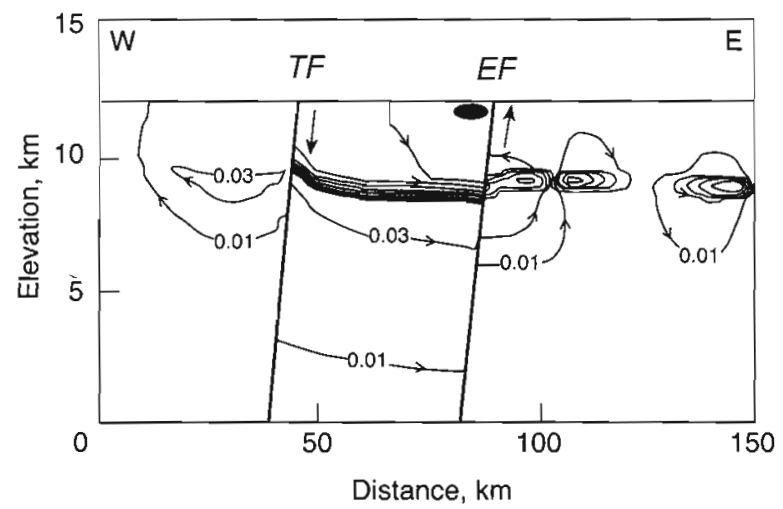

(c) Temperature

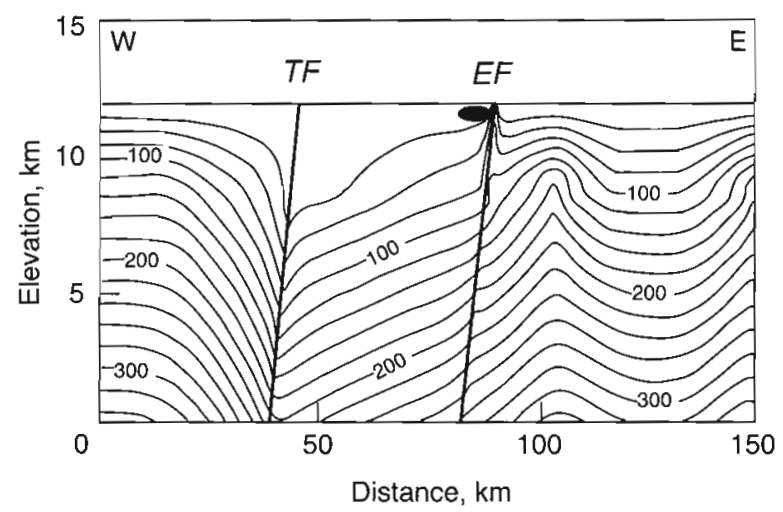

FIG. 16. Convective fluid-flow model for McArthur basin showing (a) hydrostratigraphy, (b) fluid-flow lines, and (c) temperature contours at steady state (Garven et al, 2001). This model simulates basinal fluid discharge from the upper Tawallah aquifer via the Emu fault $(\mathrm{EF})$ and marine fluid recharge via the Tawallah fault (TF). Recharge fluids move west to east through the upper Tawallah sandstone aquifer from the Tawallah to the Emu fault.

suggested in the context of the genesis of the stratiform $\mathrm{Zn}$ $\mathrm{Pb}-\mathrm{Ag}$ ores of northern Australia by Solomon and Heinrich (1992), who proposed high heat-producing granites were necessary to drive the hydrothermal cells. However, the more recent work (Garven et al., 2001; Yang et al., 2004b) suggests that normal rift-related geothermal gradients are sufficient to drive the hydrothermal system.

Garven et al. (2001) proposed a two-phase hydrologic model for the regional mineralizing system. The first and longest phase was the $\sim 70-\mathrm{m} . \mathrm{y}$-long period of relative tectonic quiescence, which followed deposition of the clastic rocks that formed the future main aquifer. This stable basin environment promoted deposition of the platform carbonates of the McArthur Group that acted as a regional seal beneath which convective circulation cells developed (e.g., flowlines to the east of the Emu fault; Fig. 16b). Although flow was focused in the main aquifer, fluids also circulated, albeit at low velocities, within the clastic and volcanic units lower in the section, greatly increasing the volume of the potential metal source area. Geologic evidence from the McArthur River deposit and its environs indicates that the mineralizing event (second phase of the model) was coincident with a discrete episode of basin tectonism, which involved predominantly strike-slip displacement on the adjacent Emu fault and associated faults. This second phase of the hydrologic model corresponds to fault displacement, related increased permeability, and migration of hot, connate brines (Fig. I6b, c) from the aquifer, up the Emu fault, and onto the sea floor. Temperatures of as high as $140^{\circ} \mathrm{C}$, depending on the model parameters used, characterized the discharging fluids, whereas simultaneously they were being replaced by cold seawater descending along the Tawallah fault and other active faults (Yang et al., 2004b).

The above hydrologic models assume saline basinal fluids, because this increases the solubility of the target metals, particularly at the relevant temperatures (e.g., Cooke et al., 2000). However, by virtue of its effect on fluid density, salinity is also a potential control on convective fluid-flow patterns. Yang et al. (2004a) have coupled transient fluid flow, heat transfer, and solute transport to examine the effects of varying the salinity of the McArthur basin hydrologic model. The scenario proposed to best fit the geology of the southern McArthur basin had initial conditions of moderate fluid salinity at the basin floor and through the relatively low permeability McArthur Group carbonate seal (avg 10 wt $\% \mathrm{NaCl}$ ), and highly saline pore fluids in the main porous aquifer ( $20 \mathrm{wt}$ $\% \mathrm{NaCl}$ ). This configuration promotes free convection and ultimate development of the west to east fluid-flow pattern consistent with the formation of the McArthur River deposit. The modeling demonstrated that dense brines resident in the aquifer can sink into the less permeable basement volcanic units, become heated and convect back up into the aquifer, potentially enhancing scavenging of metal from the basement volcanic and sedimentary rocks (Yang et al., 2004a, fig. 2).

\section{Topographic and/or deformation-driven models}

In the topographic and deformation-driven hydrologic model proposed for Century (Broadbent et al., 1998; Ord et al., 2002), the regional migration of fluids is due to the hydraulic head developed in response to meteoric water recharge in highlands to the southeast, which was initiated soon after the onset of the Isan orogeny (App. Fig. A8). In this model, the late diagenetic timing proposed for the Century mineralization (Broadbent et al., 1998) necessitates fluid 
infiltration into the relatively impermeable siltstone host rocks to form the stratiform mineralization. Broadbent et al. (1998) and Ord et al. (2002) proposed that hydraulic fracturing of the fine-grained, compacted sediments was the key method of ore-fluid infiltration and occurred by a combination of high internal fluid pressure and the stress field generated during basin inversion. Although the development of hydraulic fracture networks is an appealing way to facilitate permeability and mineralization in buried, compacted finegrained, and, hence, low-permeability sedimentary rocks, Ord et al. (2002) made no attempt to reconcile this process with the ore textures at Century, which are very similar to those exhibited by other sea-floor SEDEX deposits and unlike those expected from hydraulic fracturing and mineralization of a lithified sedimentary rock. It is thus difficult to accept that hydraulic fracturing had a role to play in the formation of the main ore type at Century, and consequently the proposed topography- and deformation-driven models appear to be unrealistic (cf. Cathles and Adams, 2005).

\section{Chemical Models for Mineralization}

\section{Fluid chemistry}

Although definitive fluid inclusion data are not available for the northern Australian $\mathrm{Zn}-\mathrm{Pb}-\mathrm{Ag}$ deposits, studies of other SEDEX systems indicate that the ore fluids are likely to have been metalliferous connate brines derived from their host basins (e.g., Lydon, 1983; Hanor, 1994). Chemical models for metal transport and deposition in stratiform $\mathrm{Zn}-\mathrm{Pb}-\mathrm{Ag}$ deposits fall into two groups (Cooke et al., 2000), which are dependent on the nature of the ore fluid. In reduced, moderateto high-temperature $\left(200^{\circ}-300^{\circ} \mathrm{C}\right)$, acidic, saline fluids, $\mathrm{H}_{2} \mathrm{~S}$ is the dominant sulfur species (Lydon, 1983; Solomon and Heinrich, 1992; Goodfellow et al., 1993). In contrast, in oxidixed, moderate- to low-temperature $\left(100^{\circ}-250^{\circ} \mathrm{C}\right)$, neutral to slightly alkaline saline brines, $\mathrm{SO}_{4}^{2-}$ is the dominant sulfur species (Williams, 1978a; McGoldrick and Keays, 1990; Hinman, 1996; Large et al., 1998).

Cooke et al. (2000) proposed that the composition of the sedimentary basin fill controls the redox nature of the basinal brines and suggested a two-fold classification of SEDEX deposits based on brine type. McArthur-type deposits, which include those in northern Australia, precipitate from relatively cool $\left(100^{\circ}-200^{\circ} \mathrm{C}\right)$, near-neutral $\mathrm{pH}$, oxidized brines developed within sedimentary basins dominated by sandstones and carbonates. The deposits tend to be large tonnage, distal from vent, have a lack of barite, and contain background concentrations of tin and gold. In contrast, Selwyn-type deposits form from hotter $\left(200^{\circ}-300^{\circ} \mathrm{C}\right)$, acidic and reduced brines, developed within sedimentary basins dominated by shales and turbiditic sandstones. The deposits may range from small to large tonnage, are proximal to vent, commonly contain barite, and have anomalous levels of gold and tin. A heat engine (commonly mafic intrusions) may be necessary to raise the temperature of the reduced basinal brines to a level necessary for significant base metal transport. Sullivan, Rammelsberg, Red Dog, and most of the Selwyn basin deposits are considered to be of this type (e.g., Goodfellow et al. 1993). Broken Hill-type deposits (including Cannington) probably also form from reduced fluids, but of moderate temperature $\left(100^{\circ}-200^{\circ} \mathrm{C}\right)$, and occur in a dominantly oxidized basin setting, compared to the reduced basins typical of SEDEX deposits (Large et al., 1996).

An important aspect of oxidized, sulfate-bearing, sedimentary brines, which may account for the high metal grades in the McArthur-type deposits of northern Australia, is their ability to carry significant quantities of zinc and lead at moderate temperatures and near-neutral pH (Fig. 17; Large et al., 1998; Cooke et al., 2000). Thermodynamic modeling shows that relatively oxidized fluids near the pyrite-hematite boundary can carry between 100 to $1,000 \mathrm{ppm} \mathrm{Zn}$, in contrast with reduced fluids at the same temperature, $\mathrm{pH}$, and salinity that can carry between 1 and $1.00 \mathrm{ppm} \mathrm{Zn} \mathrm{(Fig.} \mathrm{17).}$

\section{Metal-deposition processes}

The $\mathrm{pH}-f_{\mathrm{O}_{2}}$ values of metal transport for the oxidized fluids that produce the northem Australian SEDEX deposits (McArthur-type), compared to the reduced fluids that produce Selwyn-type deposits, are shown in Appendix Figure A9 (Cooke et al., 2000). It is evident that metal deposition from oxidized brines can only occur by sulfate reduction or mixing with an $\mathrm{H}_{2} \mathrm{~S}$-bearing fluid; temperature decrease is unimportant (Cooke, et al., 2000). Sulfate reduction reactions are best achieved by interaction of the ore fluid with an organic carbon-rich rock unit or an organic carbon-rich fluid (e.g., anoxic brine pool or hydrocarbon reservoir). This most likely explains why all major stratiform $\mathrm{Zn}-\mathrm{Pb}-\mathrm{Ag}$ deposits are located in organic-rich shale host rocks.

The observations that carbonaceous material is ubiquitous and abundant in all the Australian sedimentary rock-hosted $\mathrm{Zn}-\mathrm{Pb}-\mathrm{Ag}$ deposits (except Cannington, a Broken Hill-type deposit), as well as the fact that there is a broad range in $\delta^{34} \mathrm{~S}$ sulfide values in the ores and related pyritic sediments, together with textural and fossil evidence for a diverse microbial biota associated with some deposits (Oehler and Logan, 1977; McGoldrick, 1999), suggest a role for microorganisms in the ore-forming process. This is particularly likely for ventdistal deposits that form in low-temperature brine pools where optimal conditions exist for microbial proliferation (McGoldrick, 1999; Ireland et al., 2004b). Trends toward isotopically heavy sulfur upsection in some deposits (e.g., Mc Arthur River; Lady Loretta) suggest BSR in a sulfate-limited

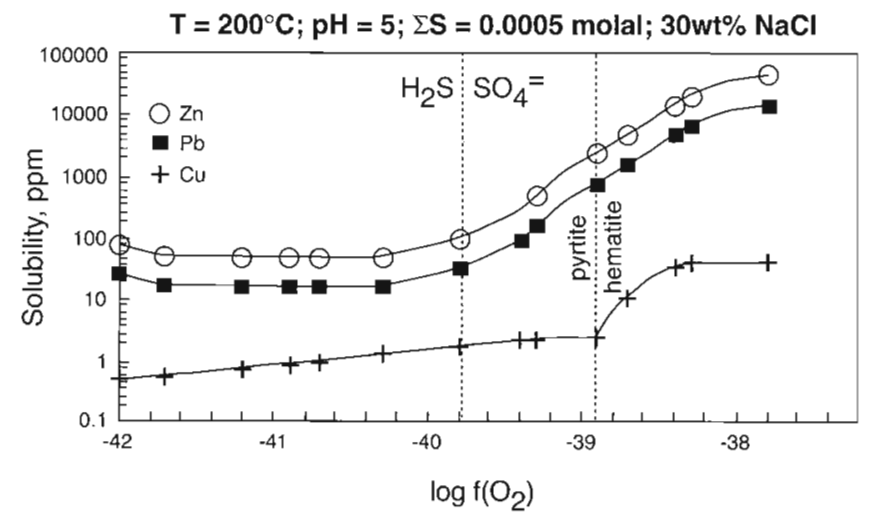

FIG. 17. Variation in metal solubility with $f_{\mathrm{O}_{2}}$, showing that high-salinity oxidized (sulfate-bearing) brines can carry significantly more $\mathrm{Zn}$ and $\mathrm{Pb}$ than reduced ( $\mathrm{H}_{2} \mathrm{~S}$-bearing) brines (Large et al., 1998). 
closed-system, or, at the least, partly closed-system conditions (e.g., Smith and Croxford, 1975; McGoldrick et al., 1996). However, for other deposits (e.g., Mt. Isa: Painter et al., 1999; Dugald River: Dixon and Davidson, 1996), TSR (coupled with oxidation of organic matter) is the likely mechanism for sulfide deposition. Further research combining sulfur isotopes with geothermometry and organic geochemistry is required to resolve the importance of BSR versus TSR in these deposits (e.g., Logan et al., 2001).

\section{Discussion and Conclusions}

The descriptions of the five major ( $>100 \mathrm{Mt}$ ) stratiform $\mathrm{Zn}$ $\mathrm{Pb}-\mathrm{Ag}$ deposits at McArthur River, Century, Mt. Isa, Hilton, and George Fisher clearly indicate that, although there are minor differences, the deposits exhibit similar morphological, textural, chemical, zonation, and isotopic features that suggest a common origin. All five deposits are hosted by organicbearing black siltstones. They are located close to major regional basinal faults; which were active during sedimentation and acted as conduits for transport of metalliferous sedimentary brines from deep in the Mt. Isa-McArthur basin system.

At the McArthur River deposit, where diagenetic and metamorphic overprints are minimal, preserved ore textures and, most importantly, the presence of soft sediment-deformed ore clasts of bedded $\mathrm{Zn}-\mathrm{Pb}-\mathrm{Ag}$ sulfides within the interore sedimentary breccias, convincingly demonstrate that the principal ore lenses are synsedimentary in origin. Sulfide textures in the stratiform ores indicate that both exhalative and subsea-floor replacement processes have operated. At the Century deposit, the textural and morphological evidence support a strata-parallel, diagenetic replacement process below the sea floor. Whether this was at considerable depth $(>1,000 \mathrm{~m})$ and within the overpressured zone, or at shallower depth, close to or on the sea floor, is yet to be convincingly established. For the Mt, Isa, Hilton, and George Fisher deposits, clear evidence in support of a synsedimentary origin is lacking due to textural recrystallization and remobilization of the sulfide minerals during greenschist-facies metamorphism. However, the bulk of the evidence in the least deformed of the three deposits, the George Fisher deposit, supports a shallow syndiagenetic replacement origin.

The $\delta^{34} \mathrm{~S}$ data from all the stratiform $\mathrm{Zn}-\mathrm{Pb}$-Ag deposits show a range of at least 20 per mil (Fig. A4), with the pyrite facies showing a greater variation than the base metal facies. The data support the ultimate source of the sulfur as marine sulfate, with reduction of sulfate to sulfide usually involving a combination of BSR and TSR, dependent on the temperature and position relative to the sea floor. In the least deformed deposits, it has been possible to recognize an isotopic fractionation trend to heavier $\delta^{34} \mathrm{~S}$ values in the later stages of the paragenesis, which is related to the effects of closed-system Raleigh distillation.

The main-stage lead isotopes for the major stratiform deposits are very homogeneous and overlap a terrane specific growth curve. Furthermore, the $\mathrm{Pb}-\mathrm{Pb}$ model ages of the deposits have the same relative temporal sequence as the more precise zircon $\mathrm{U}-\mathrm{Pb}$ ages of the host sedimentary rocks. This provides strong supportive evidence that all the major deposits are synsedimentary to syndiagenetic in origin (Sun et al., 1994). Although there has been considerable previous dispute about the depth of sedimentation of the host rocks for the five major deposits, it is now accepted that the organicrich siltstones formed below wave base, commonly in a tectonically active deep-water setting adjacent to major synsedimentary faults. In all cases, the host rocks display subtle lithogeochemical characteristics that define major regionally extensive strata-bound halos surrounding the ore deposits. Minor enrichments in $\mathrm{Zn}, \mathrm{Pb}$, and $\mathrm{Tl}$, and zonal changes in the iron and manganese content of sedimentary and diagenetic carbonates within the black shales are the principal characteristics of the strata-bound halos. In the case of the synsedimentary deposits (e.g., McArthur River), the halo is considered to represent the extent of the surrounding fossil brine pool. For the syndiagenetic deposits (e.g., Century) the halo represents the passage of the ore-forming fluids as they moved through more permeable sediments and away from the feeder fault and sites where they deposited most of their metals.

Numerical modeling demonstrates that synsedimentary deposits probably formed by free convection of marine waters and basinal brines driven by the normal geothermal gradient during basin rifting events. Deformation-related topographically driven fluid models do not appear to be a viable oreforming mechanism. The free convection modeling suggests that metals are sourced from mafic and felsic volcanic rocks, volcaniclastic rocks, and sandstones in the rift at depths of 5 to $10 \mathrm{~km}$ below the ore deposit host stratigraphy. Sandstone, conglomerate, and volcaniclastic aquifers enable the migration of brines through the ore-hosting basins and the development of metalliferous brine reservoirs. Regionally extensive and deeply penetrating basinal faults were critical in focussing metalliferous brines stored in the aquifers to organic-bearing sedimentary traps on or close to the basin floor.

Two major deposits in the Mt. Isa basin, Cannington and Mt. Isa Copper, do not appear to fit into the ore deposit model described above. Cannington is a highly metamorphosed lead- and silver-rich strata-bound deposit with features similar to Broken Hill. It is clearly not a metamorphosed SEDEX deposit, being hosted by oxidized siliciclastic sedimentary (not black shales) and volcanic rocks that occur deeper in the basin than the other stratiform $\mathrm{Zn}-\mathrm{Pb}$-Ag deposits. Due to the high degree of metamorphism and deformation, the sulfide mineral textures provide little evidence concerning the timing of the mineralization. However, the $\mathrm{Pb}-\mathrm{Pb}$ age of the ores is very similar to the $\mathrm{U}-\mathrm{Pb}$ zircon age of the host sediments, thus supporting a synsedimentary origin for the deposit. The lead appears to be of upper mantle derivation, which contrasts with the upper crustal source for the other major SEDEX deposits, indicating a substantially different hydrologic system.

The crosscutting Mt. Isa Copper ores are distinctly different in morphology, mineralogy, composition, textures, and alteration style compared to the stratiform $\mathrm{Zn}-\mathrm{Pb}-\mathrm{Ag}$ ores. They overprint the $\mathrm{Zn}-\mathrm{Pb}-\mathrm{Ag}$ ores, and the current structurally based interpretation is that they formed synchronous with the Isan orogeny, about 100 to 150 m.y. after deposition of the $\mathrm{Zn}-\mathrm{Pb}-\mathrm{Ag}$ ores. Three of the authors of this review strongly advocate a late timing for the copper ores based on the structural evidence (SW, GMD, GRC). However, the other three are less convinced by the structural arguments 
and consider that zonal relationships of metals, minerals, and alteration between the copper and $\mathrm{Zn}-\mathrm{Pb}-\mathrm{Ag}$ ores at Mt. Isa suggest the possibility of a single zoned syndiagenetic system (RRL, SWB, PMcG).

\section{Acknowledgments}

This paper has benefited from discussions with a large number of industry and academic geologists over the last 15 years concerning the nature and genesis of $\mathrm{Zn}-\mathrm{Pb}-\mathrm{Ag}$ deposits. Thanks also to AMIRA International and the Australian Research Council for providing funding to enable much of this research to proceed. Two Economic Geology reviewers, Peter Betts and Karen Kelley, provided useful and critical comments. Rich Goldfarb and Jeff Hedenquist were very helpful in polishing the final outcome.

\section{REFERENCES}

Andrew, A.S., Heinrich, C.A., Wilkins, R.W.T., and Patterson, D.J., 1989, Sulfur isotope systematics of copper ore formation at Mount Isa, Queensland, Australia: ECONOMIC GEOLOGY, v. 84, p. 1614-1626.

Andrews, S.J., 1998, Stratigraphy and depositional setting of the Upper McNamara Group, Lawn Hill region: ECONOMIC GEOLOGY, v. 93, p. 1132-1152.

Annels A.E., 1974, Some aspects of the stratiform ore deposits of the Zambian Copperbelt and their genetic significance, in Bartholomé, P., ed., Gisements stratiformes at provinces cuprifères: Liège, Société Géologique de Belgique, p. 235-54.

Beardsmore, T.J., Newbery, S.P., and Laing, W.P., 1988, The Maronan Supergroup, an inferred early volcanosedimentary rift sequence in the Mount Isa Inlier; and its implications for ensialic rifting in the middle Proterozoic of Northwest Queensland: Precambrian Research, v. 40/4l, p. 487-507.

Beeson, R., 1990, Broken Hill-type lead-zinc deposits-an overview of their occurrence and geological settings: Transactions of the Institution of Mining and Metallurgy, v. 99, p. B163-B175.

Bell, T.H., 1983, Thrusting and duplex formation at Mount Isa, Queensland, Australia: Nature, v. 304, p. $493-497$.

Bell, T.H., and Hickey, K.A., 1998, Multiple deformations with successive subvertical and subhorizontal axial planes in the Mount Isa region, their impact on geometric development and significance for mineralization and exploration: ECONOMIC GEOLOCY, v. 96, p. 1369-1389

Bell, T.H., Perkins, W.G., and Swager, C.P., 1988, Structural controls on the development and localization of syntectonic copper mineralization at Mount Isa, Queensland: ECONOMIC GEOLOGY, v. 83, p. 69- 85.

Betts, P.G., and Lister, G.S., 2001, A comparison of the "strike-slip" versus the "episodic rift-sag" models for the origin of the Isa superbasin. Australian Journal of Earth Sciences, v. 48, p. 265-280.

- 2002 , Geodynamically indicated targeting strategy for shale-hosted mas-

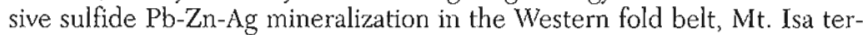
rane: Australian Journal of Earth Sciences, v. 49, p. 985-1010.

Betts, P.G., Giles, D., and Lister, G.S., 2003, Tectonic environment of shalehosted massive sulfide $\mathrm{Pb}-\mathrm{Zn}-\mathrm{Ag}$ deposits of Proterozoic northeastem Australia. ECONOMIC GEOLOGY, v. 98 , p. 557-576.

Blainey, G., 1960, Mines in the Spinifex-the story of Mount Isa Mines: Sydney, Angus and Robertson, $242 \mathrm{p}$.

Blake, D.H., 1987, Geology of the Mount Isa inlier and environs, Queensland and Northem Territory: Bureau of Mineral Resources Journal of Australian Geology and Geophysics Bulletin 225, 83 p.

Blanchard, R., and Hall, G., 1942, Rock deformation and mineralization at Mount Isa: Australasian Institute of Mining and Metallurgy Proceedings, v. 1.25 , p. I- 60

Bodon, S.B., 1998, Paragenetic relationships and their implications for ore genesis at the Cannington $\mathrm{Ag}-\mathrm{Pb}-\mathrm{Zn}$ deposit, Mt. Isa inlier, Queensland, Australia: ECONOMIC GEOLOGY, v. 93, p. 1463-1489.

2002, The Cannington Ag-Pb-Zn deposit, Mount Isa inlier, Queensland: Unpublished PhD thesis, Hobart, Tasmania, Centre for Ore Deposit Research, University of Tasmania, $337 \mathrm{p}$

Brescianini, R.F., Asten, M.W., and McLean, N., 1992, Geophysical characteristics of the Eloise Cu-Au deposit, NW Queensland: Exploration Geophysics, v. 23 , p. $33-42$.
Broadbent, G.C., and Waltho, A.E., 1998, Century lead-zinc deposit: Australasian Institute of Mining and Metallurgy Monograph 22, p. 729-736.

Broadbent, G.C., Myers, R.E., and Wright, J.V., 1998, Geology and origin of shale-hosted $\mathrm{Zn}-\mathrm{Pb}$-Ag mineralization at the Century deposit, northwest Queensland, Australia: ECONOMC GEOlogx, v. 93, p. 1264-1294.

Broadbent, G.C., Andrews, S.J., and Kelso, I.J., 2002, A decade of new ideas Geology and exploration history of the Century $\mathrm{Zn}-\mathrm{Pb}-\mathrm{Ag}$ deposit, northwestern Queensland, Australia: Society of Economic Geologists Special Publication 9, p. 119-140.

Bull, S.W., 1998, Sedimentology of the Palaeoproterozoic Barney Creek Formation in DDH BMR McArthur 2, southern McArthur basin, Northem Territory: Australian Journal of Earth Sciences, v. 45, p. 21-31.

2001. Implications of tectono-sedimentary setting for genetic and ex ploration models for northem Australian Proterozoic sediment-hosted $\mathrm{Zn}$ Pb-Ag deposits [ext. abs.]: Townsville, Queensland, Australia, James Cook University of North Queensland, Economic Geology Research Unit Contribution 59 , p. $34-35$.

Bull, S.W., and J.R., Rogers, 1996, Recognition and significance of an early compressional deformation event in the Tawallah Group, McArthur basin, N.T.: Townsville, Queensland, Australia, James Cook University of North Queensland, Economic Geology Research Unit Contribution 55, p. 28-32.

Butt, C.M. and Smith, R.E., 1980, Conceptual models in exploration geochemistry: Joumal of Geochemical Exploration, v. 12, p. 89-365.

Carne, R.C., and Cathro, R.J., 1982, Sedimentary exhalative (sedex) zinclead-silver deposits, northem Canadian Cordillera: CIM Bulletin, v. 840, p. 66-78.

Carr, G.R., Sun, S., Page, R.W., and Hinman, M., 1996, Recent developments in the use of lead isotope model ages in Proterozoic terrains [abs]: Townsville, Queensland, Australia, James Cook University of North Queensland, Economic Geology Research Unit Contribution 55, p. 33-35. Carr, G.R., Denton, G.J., Korsch, M.J., Parr, J.M., Andrew, A.S., Whitford, D., Wyborn, L.A.I, and Sun, S-S., 2001, User friendly isotope technologies in mineral exploration: Northem Australian Proterozoic basins: Australian Mineral Industry Research Assocation Final Report P480, 313 p. (4 volumes)

Carr, G.R., Denton, G.J., Parr, J., Sun, S., Korsch, M.J., and Bodon, S.B., 2004, Lightning does strike twice: Multiple ore events in major mineralised systems in northern Australia [ext. abs.]: Centre for Global Metallogeny, University of Western Australia Publication 33, p. 332-335.

Carter, E.K., Brooks, I.H., and Walker, K.R., 1961, The Precambrian mineral belt of northwest Queensland: Bureau of Mineral Resources Journal of Australian Geology and Geophysics Bulletin 51,344 p.

Chapman, L.H., 1999, Geology and genesis of the George Fisher Zn-Pb-Ag deposit, Mount Isa, Australia: Unpublished Ph.D. thesis, Townsville, Australia, James Cook University, 315 p.

-_-2004, Geology and mineralization styles of the George Fisher $\mathrm{Zn}-\mathrm{Pb}-\mathrm{Ag}$ deposit, Mount Isa, Australia: ECONOMIC GEOLOGY, v. 99, p. 233-256.

Chapman, L.H., and Williams, P.J., 1998, Evolution of pyroxene-pyroxenoidgarnet alteration at the Cannington $\mathrm{Ag}-\mathrm{Pb}-\mathrm{Zn}$ deposit, Cloncurny district, Queensland, Australia: ECONOMIC GEOLOGY, v. 93, p. 1390-1405.

Chen, I., Walter, M.R., Logan, G.A., Hinman, M.C., and Summons, R.E. 2003, The Palaeoproterozoic McArthur River (HYC) Pb-Zn-Ag deposit of northern Australia: Organic chemistry and ore genesis: Earth and Planetary Science Letters, v. 210 , p. $467-479$.

Collins W.J., and Shaw, R.D., 1995, Geochronological constraints on orogenic events in the Arunta inlier: A review: Precambrian Research, v. 7l, p $315-346$.

Cooke, D.R., Bull, S.W., Donovan S., and Rogers, I.R., 1998, K-metasomatism and base metal depletion in volcanic rocks from the McArthur basin, Northern Territory-implications for the base metal mineralization: EcoNOMIC GEOLOGX, v. 93, p. 1237-1263.

Cooke, D.R., Bull, S.W., Large, R.R., and McGoldrick, P.I., 2000, The importance of oxidized brines for the formation of Australian Proterozoic stratiform sediment-hosted $\mathrm{Pb}-\mathrm{Zn}$ (Sedex) deposits: ECONOMIC GEOLOGY, v. 95, p. $1-18$.

Crick, I.H., 1992, Petrological and maturation characteristics of organic matter from the Middle Proterozoic McArthur basin, Australia: Australian Journal of Earth Sciences, v. 39, p. 501-519.

Crick, I.H., Boreham C.J., Cook A.C., and Powell T.G., 1988, Petroleum geology and geochemistry of Middle Proterozoic McArthur basin, Northern Australia. II: Assessment of source rock potential: Bulletin of American Association of Petroleum Geology, v. 72, p. 1495-1514. 
Croxford, N.J.W., and Jephcott, S., 1972, The McArthur lead-zinc-silver deposit, Northern Territory: Proceedings of the Australasian Institute of Mining and Metallurgy, v. 243, p. 1-26.

Cumming, G.L., and Richards, J.R., 1975, Ore lead isotope ratios in a continuously changing earth: Earth and Planetary Science Letters, v. 28, p. $155-171$.

Davis, T.P., 2004, Mine-scale structural controls on the Mt. Isa $\mathrm{Zn}-\mathrm{Pb}-\mathrm{Ag}$ and Cu orebodies: ECONOMIC GEOLOGY, v. 99, p. 543-560.

Derrick, G.M., 1976, Some insights into old and new zinc mineralization at Dugald River and Squirrel Hills, and uranium mineralization at Mary Kathleen, Queensland: Journal of Australian Geology and Geophysics, v. 1, 251 p

-1982, A Proterozoic rift zone at Mount Isa, Queensland, and implications for mineralization: Journal of Australian Geology and Geophysics, v. 7 , p. $81-92$

-1996, The "geophysical" approach to metallogeny of the Mt. Isa inlierwhat sort of orebody do you want?: Australasian Institute of Mining and Metallurgy Annual Conference, Perth, March 1996, Proceedings, p. 349-366.

Dixon, G., and Davidson, G.J., 1996, Stable isotope evidence for thermochemical sulphate reduction in the Dugald River (Australia) stratabound shale-hosted zinc-lead deposit: Chemical Geology, v. 129, p. 227-246.

Domogala, J., Southgate, P.N., McConachie, B.A., and Pidgeon, B.A., 2000, Evolution of the Palaeoproterozoic Prize, Gun and lower Loretta supersequences of the Surprise Creek Formation and Mt. Isa Group: Australian Journal of Earth Sciences, v. 47, p. 485-508.

Dunster, J.N., 1996, Sedimentology of the Lady Loretta Formation-a comparison of the regional setting to that of the Lady Loretta orebody [ext. abs.1: Townsville, Queensland, Australia, James Cook University of North Queensland, Economic Geology Reseaxch Unit Contribution 55, p. 47-50.

Eldridge, C.S., Williams, N., and Walshe, J.L., 1993, Sulfur isotope variability in sediment-hosted massive sulfide deposits as determined using the ion microprobe SHRIMP: II. A study' of the H.Y.C. deposit at McArthur River, Northern Territory, Australia.

Eriksson, K.A., Simpson, E.L. and Jackson, M.J., 1993, Stratigraphical evolution of a Proterozoic syn-rift to post-rift basin: Constraints on nature of lithospheric extension in the Mount Isa inlier, Australia: International Association of Sedimentologists Special Publication 20, p. 203-221.

Feltrin, L., Oliver, N., Chapman, L., and Kelso, I., 2004, Evolution of mineralised breccias at the Century zine deposit, northwestern Queensland, Australia [abs.]: Geological Society of Australia, Australian Geological Convention, $17^{\text {th }}$, Hobart, February 2004 , Abstracts 73 , p.75.

Finlow-Bates, T., and Stumpfl, E.F., 1985, Lead isotope studies bearing on the genesis of copper orebodies at Mount Isa, Queensland and Mount Isa silica dolomite and copper orebodies, the result of syntectonic hydrothermal alteration system-a discussion: ECONOMIC GEOLOGY, v. 80, p. 184-188.

Forrestal, P.J., 1990, Mount Isa and Hilton silver-lead-zinc deposits, in Hughes, F.E., ed., Geology of the mineral deposits of Australia and Papua New Guinea: Melbourne, Australasian Institute of Mining and Metallurgy, p. $927-934$

Garven, G., Bull, S.W., and Large, R. R. 2001, Hydrothermal fluid flow models of stratiform ore genesis in the McArthur basin, Northern Territory, Australia: Geofluids, v. 1, p. 289-311.

Giles, D., and Nutman, A.P., 2003, SHRIMP U-Pb zircon dating of the host rocks of the Cannington $\mathrm{Ag}-\mathrm{Pb}-\mathrm{Zn}$ deposit, southeastem $\mathrm{Mt}$. Isa block, Australia: Australian Joumal of Earth Sciences, v. 50, p. 295-309.

Giles, D., Betts, P., and Lister G., 2002, Far-field continental backarc setting for the 1.80-1.67 Ga basins of northeastem Australia: Geology, v. 30, p. 823-826.

Goodfellow, W.D., Lydon, J.W., and Turner, R.J.W., 1993, Geology and genesis of stratiform sediment-hosted (SEDEX) zinc-lead-silver sulfide deposits: Geological Association of Canada Special Paper 40, p. 201-253.

Grondijis, H.F., and Schouten, C., 1937, A study of the Mt. Isa ores: EcoNOMIC GEOLOGY, v. 32, p. 407-450.

Gulson, B.L., 1986, Lead isotopes in mineral exploration: Amsterdam, Netherlands, Elsevier, $245 \mathrm{p}$.

Gulson, B.L., Perkins, W., and Mizon, K. J., 1983, Lead isotope studies bearing on the genesis of copper orebodies at Mt. Isa, Queensland: ECONOMIC GEOLOGY, v. 78, p. 1466-1504.

Gustafson, L.B, and Williams, N., 1981, Sediment-hosted stratiform deposits of copper, lead and zinc: ECONOMIC GEOLOGY $75^{\mathrm{TH}}$ ANNIVERSARY VOLUME, p. $139-178$.
Hanor, I.S., 1994, Origin of saline fluids in sedimentary basins: Geological Society Special Publication 78, p. 151-174.

Hartman, M., Scholten, J.C., Stoffers, P., and Wehner, F., 1997, Hydrographic structure of brine-filled deeps in the Red Sea; new results from the Shaban, Kebrit, Atlantis 11 and Discovery Deep: Marine Geology, v. 4, p. $311-330$

Heinrich, C.A., Andrew, A.S., Wilkins, R.W.T., and Patterson, D.T., 1989, A fluid inclusion and stable isotope study of synmetamorphic copper ore formation at Mount Isa, Australia: ECONOMIC GEOLOGY, v. 84, p. 529-550.

Hinman, M., 1996, Constraints, timing and processes of stratiform base metal mineralization at the $\mathrm{HYC} \mathrm{Ag}-\mathrm{Pb}-\mathrm{Zn}$ deposit, McArthur River: Townsville, Queensland, James Cook University, Economic Geology Research Unit Contribution 55, p. 56-59.

Hinman, M.C., 1995, Base metal mineralization at McArthur River: Structure and kinematics of the HYC-Cooley zone at McArthur River: Australian Geological Survey Organisation Record 1995/5, 29 p.

Huston D.L., and Large R.R., 1989, A chemical model for the concentration of gold in volcanogenic massive sulfide deposits: Ore Geology Reviews, v. 4, p.171-200.

Ireland, T., Bull, S.W., and Large, R.R., 2004a, Mass flow sedimentology within the McArthur River $\mathrm{Zn}-\mathrm{Pb}-\mathrm{Ag}$ deposit (HYC), Northern Territory, Australia: Evidence for syn-sedimentary ore genesis: Mineralium Deposita, v. 39, p. $143-158$

Ireland, T., Large, R.R., McGoldrick, P., and Blake, M., 2004b, Spatial distribution patterns of sulfur isotopes, nodular carbonate and ore textures in the McArthur River (HYC) Zn-Pb-Ag deposit, Northern Territory, Australia: ECONOMIC GEology, v. 99, p. 1687-1710

Jackson, M.J., Muir, M.D., and Plumb, K.A., 1987, Geology of the southern McArthur basin, Northern Territory: Australia, Bureau of Mineral Resources Bulletin 220, $173 \mathrm{p}$.

Jackson, M. \}., Scott D.L., and Rawlings, D.J., 2000, Stratigraphic framework for the Leichhardt and Calvert superbasins: Review and correlations of the pre-1700 Ma successions between Mt. Isa and McArthur River: Australian Journal of Earth Sciences, v. 47, p. 381-404.

Knight, C.L., 1953, Regional geology of Mount Isa, in Edwards, A.B., ed, Geology of Australian ore deposits: Melbourne, Australasian Institute of Mining and Metallurgy, v. 1, p. 352-360.

Krassay, A.A., Domogala, J., Bradshaw, B.E., and Southgate, P.N., 2000 , Lowstand ramps, fans and deep water Palaeoproterozoic and Mesoproterozoic facies of the Lawn Hill platform: the Term, Lawn, Wide and Doom supersequences of the Isa superbasin, northern Australia: Australian Journal of Earth Sciences, v. 47, p. 563-598.

Lambert, I.B., 1976, The McArthur zinc-lead-silver deposit: Features, metallogenesis and comparisons with some other stratiform ores, in Wolf, K.H. ed, Handbook of strata-bound and stratiform ore deposits: Amsterdam, Elsevier, v. 6., p. 535-585.

Lambert, I.B., and Scott, K.M., 1973, Implications of geochemical investigations of sedimentary rocks within and around the McArthur zinc-lead-silver deposit, Northern Territory: Journal of Geochemical Exploration, v. 2, p. $307-330$.

Large, D.E., 1983, Sediment-hosted massive sulfide lead-zinc deposits: Aan empirical model: Mineralogical Association of Canada Short Course Handbook, v. 8, p. 1- -30 .

Large, R.R., and McGoldrick, P.J., 1998. Lithogeochemical halos and geochemical vectors to stratiform sediment-hosted $\mathrm{Zn}-\mathrm{Pb}-\mathrm{Ag}$ deposits, Part $\mathrm{l}$ : Lady Loretta deposit, Queensland: Journal of Geochemical Exploration, v. 63 , p. $37-56$

Large, R.R., Bodon, S., Davidson, G.J., and Cooke, D.R., 1996, The chemistry of BHT ore formation--one of the keys to understanding the differences between SEDEX and BHT deposits: Hobart, University of Tasmania, CODES Special Publication 1, p. 105-111.

Large, R.R., Bull, S.W., Cooke, D.R., and McGoldrick, P.J., 1998, A genetic model for the HYC deposit, Australia, based on regional sedimentology, geochemistry, and sulfide-sediment relationships: ECONOMC GEOLOGY, v. 93 , p. $1345-1569$.

Large, R.R., Bull, S.W., and McGoldrick, P.J., 2000, Lithogeochemical halos and geochemical vectors to stratiform sediment hosted $\mathrm{Zn}-\mathrm{Pb}-\mathrm{Ag}$ deposits. Part 2: HYC deposit, Northern Territory: Journal of Geochemical Exploration, v. 64 , p. $105-126$.

Large, R.R., Bull, S.W., and Winefield, P.R., 2001a, Carbon and oxygen isotope halo in carbonates related to the McArthur River (HYC) $\mathrm{Zn}-\mathrm{Pb}$-Ag deposit, North Australia: Implications for sedimentation, ore genesis, and mineral exploration: ECONOMIC GEOLOGY, v. 96, p. 1567-1593. 
Large, R.R., Bull, S.W., and Foden, I., 2001b, C, O and Sr isotopic halos related to the giant McArthur River stratiform $\mathrm{Zn}-\mathrm{Pb}$-Ag deposit, northerm Australia, in Piestrzynski et al., eds., Mineral deposits at the beginning of the $21^{\text {st }}$ century: Lisse, Swets and Zeitlinger, p. 219-222.

Large, R.R., Bull, S.W., Selley, D, Yang, J., Cooke, D., Garven, G., and McGoldrick, P., 2002, Controls on formation of giant stratiform sedimenthosted $\mathrm{Zn}$ - $\mathrm{Pb}$-Ag deposits: with particular reference to the north Australian Proterozoic: Hobart, University of Tasmania, CODES Special Publication 4, p. $107-149$.

Large, R.R., McGoldrick, P., Bull, S.W., and Cooke, D.R., 2004, Proterozoic stratiform sediment-hosted zinc-lead-silver deposits of northern Australia, in Deb, M., and Goodfellow, W.D., eds., Sediment-hosted lead-zinc sulfide deposits: Attributes and models of some major deposits in India: Australia and Canada: New Dehli, India, Narosa Publishing House, p. 1-23.

Leach, D.L., Sangster, D.F., Kelley, K.D., Large, R.R., Garven, G., Allen, C.R., Gutzmer, J., and Walters, S., 2005, Sediment-hosted lead-zinc deposits: A global perspective: ECONOMIC GEOLOGY $100^{\text {Th }}$ ANNIVERSARY VOLUME, p. 561-607.

Leaman, D.E., 1998, Structure, contents and setting of $\mathrm{Pb}-\mathrm{Zn}$ mineralization in the McArthur basin, northern Australia: Australian Journal of Earth Sciences, v. 45 , p. 3-20.

Lindsay, J.F., and Brasier, M.D., 2000, A carbon isotope reference curve for ca. $1700-1575 \mathrm{Ma}$, McArthur and Mount Isa basins, northern Australia: Precambrian Research, v. 99, p. 271-308.

Logan, G.A., Hinman, M.C., Walter, M.R., and Summons, R.E., 2001, Biogeochemistry of the 1640 Ma McArthur River (HYC) lead-zinc ore and host sediments, Northern Territory, Australia: Geochimica et Cosmochimica Acta, v. 65, p. 2317-2336.

Logan, R.G., 1979, The geology and mineralogical zoning of the H.Y.C. Ag$\mathrm{Pb}-\mathrm{Zn}$ deposit, McArthur River, Northem Territory, Australia: Unpublished M.Sc. thesis, Canberra, Australian National University, 187 p.

Logan, R.G., Murray, W.J., and Williams, N., 1990, HYC silver-lead-zinc deposit, McArthur River, in Hughes, F.E., ed., Geology of the mineral deposits of Australia and Papua-New Guinea: Melbourne, Australasian Institute of Mining and Metallurgy, p. 907-911.

Lydon, J.W., 1983, Chemical parameters controlling the origin and deposition of sediment-hosted stratiform lead-zinc deposits, Canada: Mineralogical Association of Canada Short Course Handbook, v. 9, p. 175-250.

2004, Genetic models for Sullivan and other SEDEX deposits, in Deb, M., and Goodfellow, W.D., eds., Sediment-hosted lead-zinc sulfide deposits: Attributes and models of some major deposits in India: Australia and Canada: New Dehli, India, Narosa Publishing House, p. 149-190.

Mark, G., Phillips, G.N., and Pollard, P.J., 1998, Highly selective partial melting of pelitic gneiss at Cannington, Cloncurry district, Queensland: Australian Journal of Earth Sciences, v. 45, p. 169-176.

Mathias, B.V., and Clark, G.J., 1975, The Mount Isa copper and silver-leadzinc orebodies-Isa and Hilton mines, in Knight, C.L., ed., Economic geology of Australia and Papua New Guinea: Melbourne, Australasian Institute of Mining and Metallurgy, p. 351-371.

McClay, K.R., 1979, Folding in silver-lead-zinc orebodies, Mount Isa, Australia: Transactions of the Institute of Mining and Metallurgy, v. 88, sec. B, p. B5-B14

McClay, K.R., and Carlisle, D.G., 1978, Mid-Proterozoic sulphate evaporates at Mount Isa mine, Queensland, Australia: Nature, v. 274, p. 240-241.

McGoldrick, P.J., 1986, Volatile and precious metal geochemistry of the Mount Isa ores and their host rocks: Unpublished Ph.D. thesis, Parkville Victoria, University of Melboume, $330 \mathrm{p}$.

1999, Northern Australian SEDEX deposits: Microbial oases in Proterozoic seas: 5th Biennial SGA Meeting and the 10th Quadrennial IAGOD Symposium, London, UK, Proceedings, v. 2, p. 885-888.

McGoldrick, P.J., and Keays, R.R., 1990, Mount Isa copper and lead-zinc-silver deposits: Coincidence or cogenesis?: ECONOMIC GEOLOGY, v. 85, p. 641-651

McGoldrick, P.J., Dunster, J.,Cooke, D., and Aheimer, M., 1996, New observations from the Lady Loretta $\mathrm{Zn}-\mathrm{Pb}$-Ag deposit: Towards a genetic model: Townsville, Queensland, James Cook University, Economic Geology Research Unit Contribution 55, p. 81-84.

Meinert, L.D., 1993, Skarns and skarn deposits: Geoscience Canada Reprint Series 6, p. 117--134.

Meinert, L.D., Dipple, G.M., and Nicolescu, S., 2005, World skarn deposits: ECONOMIC GEOLOGY 100 Th ANNIVERSARY VOLUME, p. 299-336.

Muir, M.D., 1983, Depositional environments of host rock to northern Australian lead-zinc deposits, with special reference to McArthur River:
Mineralogical Association of Canada Short Course Handbook, v. 8, p. 141-174.

Murray, W.J., 1961, Notes on Mount Isa geology: Australasian Institute of Mining and Metallurgy Proceedings, v. 197, p. 105-136.

1975, McArthur River H.Y.C. lead-zinc and related deposits, N.T.: Australasian Institute of Mining and Metallurgy Monograph 5, 1, Metals, p. 329-338

Neudert, M., 1983, A depositional model for the Upper Mount Isa Group and implications for ore formation: Unpublished Ph.D. thesis, Canberra, Australian National University, $324 \mathrm{p}$.

Neudert, M.K., and Russell, R.E., 1981, Shallow water and hypersaline features from the middle Proterozoic Mount Isa sequence: Nature, v. 293, p. $284-286$.

Oehler, J.H., and Logan, R.G., 1977, Microfossils, cherts, and associated mineralization in the Proterozoic McArthur (HYC) lead-zinc-silver deposit: ECONOMIC GEOLOGY, v. 72, p. 1393-1409.

Ohmoto, H., and Golhaber, M.B., 1997, Sulfur and carbon isotopes, in Barnes, H.L., ed., Geochemistry of hydrothermal ore deposits, 3rd ed. New York, Wiley and Sons, p. 517-611.

Ohmoto, H., Kaiser, C.J., and Geer, K.A., 1990, Systematics of sulfur isotopes in recent marine sediments and ancient sediment-hosted basemetal deposits: University of Western Australia Extension Publication 23, p. $70-120$.

Ord, A., Hobbs, B.E. Zhang, Y., Broadbent, G.C., Brown, M., Willetts, G., Sorjnen-Ward, P., Walshe, J.L., and Zhao, C., 2002, Geodynamic modeling of the Century deposit, Mt. Isa province, Queensland: Australian Journal of Earth Sciences, v. 49, p. 1011-1039.

Page, R.W., and Sun, S-S., 1998, Aspects of geochronology and crustal evolution in the Eastern fold belt, Mt. Isa inlier: Australian Joumal of Earth Sciences, v. 45, p. 343-361.

Page, R.W., and Sweet, I.P., 1998, Geochronology of basin phases in the western Mount Isa inlier, and correlation with the McArthur basin: Australian Joumal of Earth Sciences, v. 47, p. 431-459

Page, R.W., Jackson, M.J., and Krassay, A.A., 2000, Constraining sequence stratigraphy in northem Australian basins: SHRIMP U-Pb zircon geochronology between Mount Isa and McArthur River: Australian Journal of Earth Sciences, v. 47, p. 431-459.

Painter, M.G.M., Golding, S.D., Hannan, K, and Neudert, M.K., 1999, Sedimentologic, petrographic and sulfur isotope constraints on fine-grained pyrite formation at the Mount Isa mine and environs, northwest Queensland, Australia: ECONOMIC GEOLOGX, v. 94, p. 883-912

Perkins, W.G., 1984, Mount Isa "silica dolomite" and copper orebodies: the result of a syntectonic hydrothermal alteration system: ECONOMIC GEOLOGY, v. 79 , p. 601-637.

1997, Mount Isa lead-zinc orebodies: Replacement lodes in a zoned syndeformational copper-lead-zinc system: Ore Geology Reviews, v. 12, p 61-110.

Perkins, W.G., and Bell, T.H., 1998, Stratiform replacement lead-zinc deposits: A comparison between Mount Isa, Hilton, and McArthur River: ECONOMIC GEOLOGY, v. 93, p. 1190-1212.

Pietsch, B.A., Rawlings, D.J., et al. 1991, Bauhinia Downs. Northern Territory 1:250 000 geological map series: Northern Territory Geological Survey, Map and Explanatory Notes, Sheet SE53-3.

Polito, P.A., Kyser, K.T., Golding, S. D., and Southgate, P.N., in press, A fluid inclusion and isotope study of the mineralization in the zinc-rich Burktown mineral field, Northem Australia; Central Australian Basins Symposium, Alice Springs, August 2005, Abstract Volume.

Rollinson, H.R., 1993, Using geochemical data: evaluation, presentation, interpretation: Harlow, Essex, England, Longman Scientific, 352 p.

Rye, D., and Williams, N., 1981, Studies of the base metal sulfide deposits at McArthur River, Northern Territory, Australia. III. The stable isotope geochemistry of the H.Y.C. Ridge and Cooley deposits: ECONOMIC GEOLOGY, v. 76, p. $826-842$.

Sami, T.T., James, N.P., Kyser, T.K., Southgate, P.N., Jackson, M.J., and Page, R.W., 2000, Evolution of Late Palaeoproterozoic ramp systems, Lower McNamara Group, northeastern Australia: SEPM Special Publication 65, p. 243-274.

Sangster, D.F., 2002, The role of dense brines in the formation of vent-distal sedimentary exhalative (SEDEX) lead-zinc deposits: Field and laboratory evidence: Mineralium Deposita, v. 37, p. 149-157.

Scott, D.L., Bradshaw, B.E., and Tarlowski, C.Z., 1998, The tectonostratigraphic history of the northern Lawn Hill platform, Australia: Tectonophysics, v. 300 , p. $329-358$. 
Scott, D.L., Rawlings, D.J., Page, R.W., Tarlowski, C.Z., Idnurm, M., Jackson, M.J., and Southgate, P.N., 2000, Basement framework and geodynamic evolution of the Palaeoproterozoic superbasins of north-central Australia: An integrated review of geochemical, geochronological and geophysical data: Australian fournal of Earth Sciences, v. 47, p. 341-380

Selley, D., Winefield, P.R., Bull, S.W., and Scott, R.J., 2001, Fault patterns and geometry of sub-basins active during deposition of the host sequence to the McArthur River orebody, southern McArthur basin, Northern Territory: Townsville, Queensland, James Cook University, Economic Geology Research Unit Contribution 59, p. 183-184.

Selley, D., Broughton, D., Scott, R., Hitzman, M., Bull, S., Large, R. McGoldrick, P., Croaker, M., Pollington, N., and Barra, F., 2005, Geology and mineralization of the Zambian Copperbelt: ECONOMIC GEOLOGY $100^{\mathrm{TH}}$ ANNIVERSARY VOLUME, p. 965--1000.

Simoneit, B.R.T., 1994, Lipid/bitumen maturation by hydrothermal activity in sediments of Middle Valley, Leg 139: Proceedings ODP Scientific results 139 , p. $447-465$.

Singer, D.A., 1995, World-class bases and precious metal deposits-a quantitative analysis: EConomic GEologx, v. 90, p. 88-104.

Skrzeczynski, R., 1998, The discovery of the Cannington Ag-Pb-Zn deposit, Mount Isa inlier, NW Queensland, Australia [abs.]: Pathways to Discovery Conference, Vancouver, British Columbia, Abstracts, p. 136-137.

Smith, J.W., 1981, Studies of the base metal sulfide deposits at McArthur River, Northem Territory, Australia: III: The stable isotope geochemistry of the HYC, Ridge, and Colley deposits-a discussion: ECONOMIC GEOLOGY, v. 76, p. 2257-2261

Smith, J.W, and Croxford, N.J.W., 1973, Sulfur isotope ratios in the McArthur lead-zinc-silver deposit: Nature Physical Science, v. 245, p. 10-12.

1975, An isotopic investigation of the environment of deposition of the McArthur mineralization: Mineralium Deposita, v. 13, p. 369-81.

Smith, J.W., Burns, M.S., and Croxford, N.J.W., 1978, Stable isotope studies of the origins of mineralization at Mount Isa: Mineralium Deposita, v. 13, p. $369-381$.

Smith, W.D., 2000, Genesis of the Mount Isa base metal deposit: Australasian Institute of Mining and Metallurgy Proceedings, no. 1, p. 45-56.

Solomon, M., and Groves, D.I., 2000, The geology and origin of Australia's mineral deposits: Centre for Ore Deposit Research, University of Tasmania and the Centre for Global Metallogeny, University of Western Australia Publication 32, 1002 p. (reprinted with additional material).

Solomon, M., and Heinrich, C.A., 1992, Are high-heat-producing granites essential to the origin of giant lead-zinc deposits at Mount Isa and McArthur River, Australia?: Exploration and Mining Geology, v. 1, p. 85-91.

Solomon, P.J. and Jensen, M.L., 1965, Sulfur isotope fractionation in nature with particular reference to Mt. Isa, Queensland: Commonwealth Mining and Metallurgical Congress, $8^{\text {th }}$, Melbourne, Proceedings, no. 6, p. 1275-1286.

Southgate, P.N., Scott, D.L., Sami, T.T., Domagala, J., Jackson, M.J., James, N.P., and Kyser, T.K., 2000, Basin shape and sediment architecture in the Gun supersequence: A strike-slip model for $\mathrm{Pb}-\mathrm{Zn}$ - $\mathrm{Ag}$ ore genesis at $\mathrm{Mt}$. Isa: Australian Journal of Earth Sciences, v 47, p. 509-531.

Stanley, C.R., Walters, S., Jeffrey, S. and Lawie, D., 2001, Primary lithogeochemical alteration halos associated with the Cannington Broken Hill-type $\mathrm{Ag}-\mathrm{Pb}-\mathrm{Zn}$ sediment-hosted massive sulfide deposit, Mt. Isa inlier, Queensland: Implications for genesis and mineral exploration: International Geochemical Exploration Symposium, 20 $0^{\text {th }}$, Santiago, Chile, May 2001, Abstracts with Program, p. 158-162.

Stanton, R.L., 1962, Elemental constitution of the Black Star orebodies, Mount Isa, Qld, and its interpretation: Transactions of the Institution of Mining and Metallurgy, v. 72 , p. 61-144.

_-1964, Mineral interfaces in stratiform ores: Transactions of the Institution of Mining and Metallurgy, v. 74, pt. 2, p. 45-79.

- 1965, Composition and textures of conformable ores as guides to their formation: Commonwealth Mining and Metallurgy Congress, $8^{\text {th }}$, Proceedings, v. 6, p. 1263-1268

Stanton, R.L., and Rafter, T.A., 1966, The isotopic constitution of sulfur in some stratiform lead-zinc sulfide ores: Mineralium Deposita, v. 1, p. 16-29.

Stanton, R.L., and Vaughan, J.P., 1979, Facies of ore formation: A preliminary account of the Pegmont deposit as an example of potential relations between small iron formations and stratiform sulfide ores: Australasian Institute Mining and Metallurgy, Proceedings, v. 270, p. 25-38.

Sun, S.S., Page, R.W., and Carr, G.R., 1994, Lead-isotope-based stratigraphic correlations and ages of Proterozoic sediment-hosted $\mathrm{Pb}-\mathrm{Zn}$ deposits in the Mount Isa inlier: Australian Geological Survey Organisation Research Newsletter 20, p. 1-2.
Taylor, G.F., and Scott, K.M., 1982, Evaluation of gossans in relation to leadzinc mineralization in the Mt. Isa inlier, Queensland: Joumal of Australian Geology and Geophysics, v. 7, p.159-180.

Taylor, G.F., and Thomber, M.R., 1992, Handbook of exploration geochemistry, in Butt, and Zeeger, eds., Regolith exploration geochemistry in tropical and subtropical terrain: Amsterdam, Elsevier, v. 4, p. 115-202.

Trudinger, P.A., 1992, Bacterial sulphate reduction: Current status and possible origin, in Schidlowski et al., eds., Early organic evolution: Implications for mineral and energy resources: Berlin-Hieldelberg, Springer-Verlag, p. 367-377.

Valenta, R., 1994, Deformation of host rocks and stratiform mineralization in the Hilton mine area, Mt. Isa: Australian Joumal of Earth Sciences, v. 4l, p. $429-443$

Veizer, J., Plumb, K.A., Clayton, R.N., Hinton, R.W., and Grotzinger, J.P., 1992, Geochemistry of Precambrian carbonates: V. Late Proterozoic seawater, Geochimica et Cosmochimica Acta, v. 56, p. 2487-2501.

Walker, R.N., Logan, R.G., and Binnekamp, J.G., 1977, Recent geological advances concerning the HYC and associated deposits, McArthur River, Northern Temitory: Journal of the Geological Society of Australia, v. 24, p. 365-380.

Walters, S., and Bailey, A., 1996, Geology and mineralization of the Cannington $\mathrm{Ag}-\mathrm{Pb}-\mathrm{Zn}$ deposit-an example of Broken Hill type mineralization in the Eastern succession of the Mount Isa inlier, NW Queensland: James Cook University of North Queensland, Economic Geology Research Unit Contribution 55, p. 137-1.37

- 1998, Geology and mineralization of the Cannington Ag- $\mathrm{Pb}-\mathrm{Zn}$ deposit: An example of Broken Hill type mineralization in the Eastern Succession, Mount Isa inlier, Australia: ECONOMIC GEOLOGY, v. 93, p. 1307-1330.

Walters, S., Skrzeczynski, R., Whiting, T., Bunting, F., and Amold, G., 2002, Discovery and geology of the Cannington Ag-Pb-Zn deposit, Mount Isa Eastem Succession, Australia: Development and application of an exploration model for Broken Hill-type deposits: Society of Economic Geologists Special Publication 9, p. 95-118.

Walters, S.J., 1996, An overview of Broken Hill-type deposits: Hobart, University of Tasmania, CODES Special Publication 1, p. 1-10.

Waltho, A.E., and Andrews, S.T., 1993, The Century zinc-lead deposit, northwest Queensiand: Australasian Institute of Mining and Metallurgy Centenary Conference, Proceedings, p. 41-61.

Waring, C.L., 1990, Genesis of the Mount Isa copper ore system: Unpublished Ph.D. thesis, Melbourne, Australia, Monash University, 409 p.

Waring, C.L., Heinrich, C.A., and Wall, V.J., 1998, Proterozoic metamorphic copper deposits: Journal of Australian Geology and Geophysics, v. 17, p. 239-246.

Whiting, T.H., 1996, Area selection using regional geophysical datasets, in Kennard, J. M., ed., Geoscience for the cornmunity, 13th Australian geological convention abstracts, Geological Society of Australia, v. 41, p.471.

Williams, N., 1978a, Studies of the base metal sulfide deposits at McArthur River, N.T., Australia: 1. The Cooley and Ridge deposits: ECONOMIC GEOLOGY, v. 73, p. 1005-1035.

_ 1978b, Studies of the base metal sulfide deposits at McArthur River; Northem Territory. Australia: II. The sulfide $\mathrm{S}$ and organic $\mathrm{C}$ relationships of the concordant deposits and their significance: ECONOMIC GEOLOGY, v. 73 , p. 1036-1056

Williams, P.J., Chapman, L.H., Richmond, J., Baker, T., Heinemann, N., and Pendergast, W.J., 1996, Significance of late orogenic metasomatism in the Broken Hill-type deposits of the Cloncurry district, north Queensland: Hobart, University of Tasmania, CODES Special Publication 1, p. 119-132.

Wilson, N.S.F., Zentilli, M., and Spiro, B., 2003, A sulfur, carbon, oxygen and strontium isotope study of the volcanic-hosted El Soldado manto-type copper deposit, Chile: The essential role of bacteria and petroleum: ECONOMiC GEOLOGY, v. 98, p. 163-174.

Winefield, P.R., 1999, Sedimentology and diagenetic history of late Palaeoproterozoic carbonates within the southern McArthur basin: Unpublished Ph.D. thesis, Hobart, University of Tasmania, $252 \mathrm{p}$.

Yang, J., Bull, S.W., and Large, R.R., 2004a, Numerical investigation of salinity in controlling ore-forming fluid transport in sedimentary basins: Example of the HYC deposit, northern Australia: Mineralium Deposita, v. 39, p. 622-631.

- 2004b, Factors controlling free thermal convection in faults in sedimentary basins: Implications for the formation of zinc-lead mineral deposits: Geofluids, v. 4, p. 237-247. 
